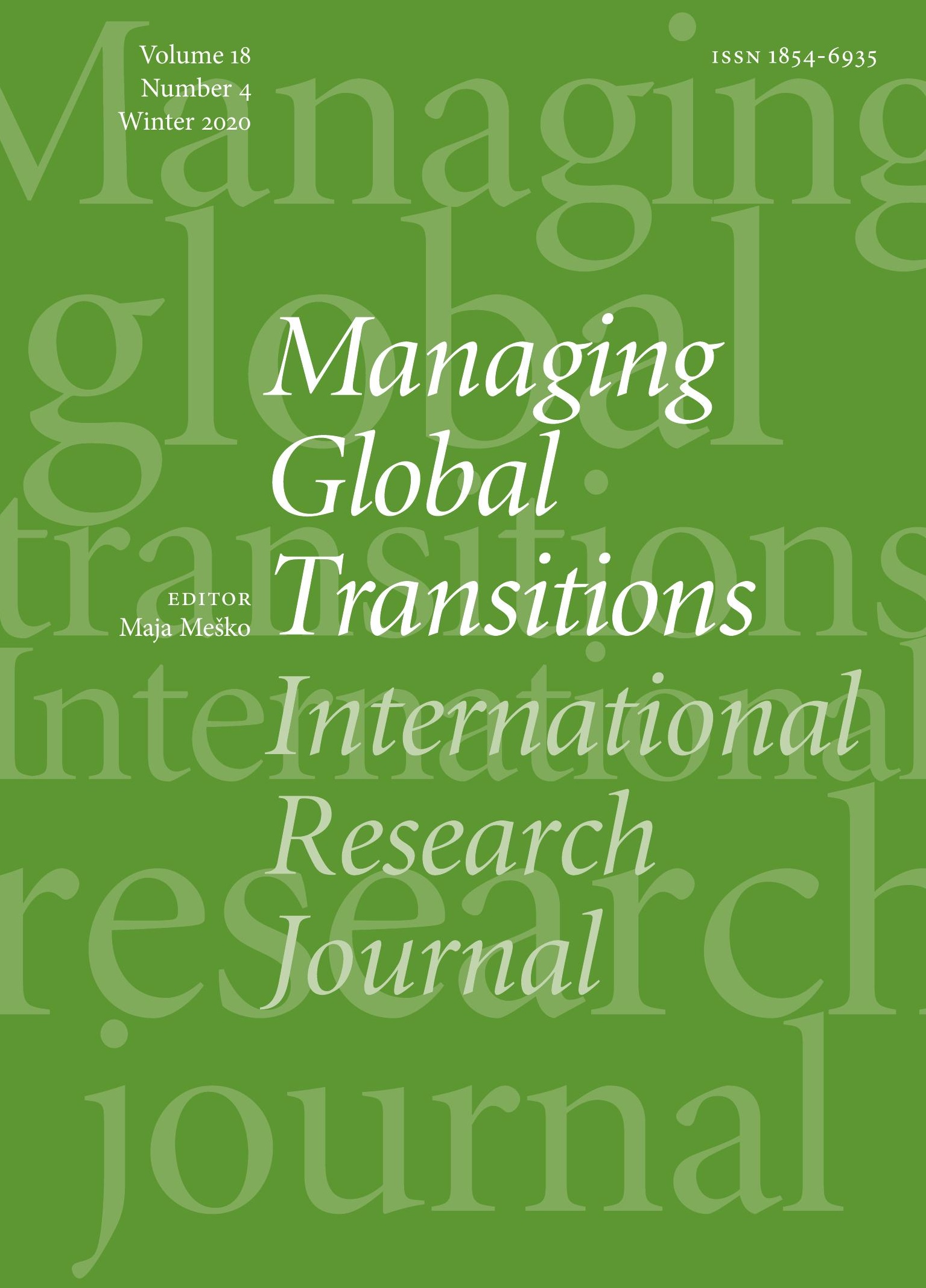




\section{Managing Global Transitions International Research Journal}

ISSN $1854-6935 \cdot$ www.mgt.fm-kp.si

EDITOR

Maja Meško, University of Primorska, Slovenia,maja.mesko@fm-kp.si

ASSOCIATE EDITORS

Andrej Bertoncelj, University of Primorska, Slovenia, andrej.bertoncelj@fm-kp.si

Gandolfo Dominici, University of Palermo, Italy,gandolfo.dominici@libero.it

Alexander Laszlo, Buenos Aires Institute of Technology, Argentina, alaszlo@itba.edu.ar

MANAGING AND PRODUCTION EDITOR

Alen Ježovnik, University of Primorska Press, Slovenia,alen.jezovnik@upr.si

EDITORIAL BOARD

Jani Bekő, Univerza v Mariboru, Slovenia, jani.beko@uni-mb.si

Heri Bezić, University of Rijeka, Croatia, bezic@efri.hr

Guido Bortoluzzi, University of Trieste, Italy, guido.bortoluzzi@deams.units.it

David L. Deeds, University of St. Thomas, usA,david.deeds@gmail.com

Evan Douglas, Griffith Universitiy, Australia, e.douglas@griffith.edu.au

Dean Fantazzini, Moscow School of Economics, Russia, fantazzini@mse-msu.ru

Henryk Gurgul, A GH University of Science and Technology, Poland, henryk.gurgul@gmail.com

András Inotai, Hungarian Academy of Sciences, Hungary, inotai.andras@krtk.mta.hu

Felicetta Iovino, University of Sannio, Italy, fiovino@unisannio.it

Hun Joon Park, Yonsei University, South Korea,hjpark@yonsei.ac.kr

Renata Karkowska, University of Warsaw, Poland,rkarkowska@wz.uw.edu.pl

Tanja Kosi Antolič, Institute of Macroeconomic Analysis and Development, Slovenia, tanja.kosi-antolic@gov.si
Leonard H. Lynn, Case Western Reserve University, UsA, leonard.lynn@case.edu Monty Lynn, Abilene Christian University, USA, monty.lynn@coba.acu.edu

Massimiliano Marzo, University of Bologna, Italy,massimiliano.marzo@unibo.it

Judita Peterlin, University of Ljubljana, Slovenia, judita.peterlin@ef.uni-lj.si

Mirjana Pejić Bach, University of Zagreb, Croatia,mpejic@efzg.hr

Sanja Peković, University of Crna Gora, Montenegro,psanja@ac.me

Sandra Penger, University of Ljubljana, Slovenia,sandra.penger@ef.uni-lj.si

Zdenko Prohaska, University of Rijeka, Croatia, zdenko.prohaska@efri.hr

José Solana Ibánez, Technical University of Cartagena, Spain, jose.solana@cud.upct.es

Marinko Škare, University of Pula, Croatia, mskare@unipu.hr

Nada Trunk Širca, International School of Social and Business Studies, Slovenia, trunk.nada@gmail.com

Šárka Velčovská, Technical University of Ostrava, Czech Republic, sarka.velcovska@vsb.cz

Manfred Weiss, Johann Wolfgang Goethe University, Germany, m.weiss@jur.uni-frankfurt.de

INDEXING AND ABSTRACTING

Managing Global Transitions is indexed/ listed in the International Bibliography of the Social Sciences, EconLit, I z Z Online, DoAJ, Erih Plus, EconPapers, Cabell's, EBsCO, and ProQuest.

SUPPORTED BY

Slovenian Research Agency.

Revija Managing Global Transitions je namenjena mednarodni znanstveni javnosti; izhaja $v$ angleščini s povzetki $v$ slovenščini. Izid revije je finančno podprla Javna agencija za raziskovalno dejavnost Republike Slovenije iz sredstev državnega proračuna iz naslova razpisa za sofinanciranje izdajanja domačih znanstvenih periodičnih publikacij. 


\section{Managing Global Transitions International Research Joumal}

VOLUME $18 \cdot$ NUMBER 4 - WINTER 2020 - ISSN 1854-6935

265 Initial Financing of Croatian smes:

Financial Reports Evidence

Roberta Kontošić Pamić and Adriana Galant

285 Relationship between Municipal Governance and Assurance Quality

Kgobalale N. Motubatse and Collins C. Ngwakwe

301 Omnipresent Social Media: Is Travelling Imaginable without Smart Devices?

Zsuzsanna Marton and Ildikó Ernszt

323 Global Transition to the Subscription Economy:

Literature Review on Business Model Changes

in the Media Landscape

Alenka Lena Klopčič, Jana Hojnik, Štefan Bojnec, and Drago Papler

349 Abstracts in Slovene 
AIMS AND SCOPE

Managing Global Transitions (MGT) is a quarterly, scholarly journal that covers diverse aspects of transitions and welcomes research on change and innovation in increasingly digitalized and networked economic environments, from a societal, organizational, and technological perspective. MGT fosters the exchange of ideas, experience and knowledge among developed and developing countries with different cultural, organizational and technological traditions. MGT invites conceptual, theorydevelopment, empirical and review papers and case-based studies advancing the field of transitions in societies, organizations and technologies.

\section{TOPICS COVERED}

\section{Transitions in Societies}

- Geo-political transitions, transition experiments, pathways and mechanisms

- Social, demographic, cross-cultural, ethical, geo-political and security aspects of transitions

- Social change, prosperity, wellbeing, happiness

- Policy making, government regulation, social responsibility

- Knowledge-based society and world futures

- New and emerging metrics for measuring, assessing and evaluating societal transitions

\section{Transitions in Organizations}

- Organizational analysis and design, modeling, developments and changes in organizational learning and behavior

- International strategy and strategic alliances, networked businesses and operations

- Entrepreneurship and leadership, decision making

- Knowledge sourcing and innovation management, personal development, education and training, HRM

- Business systems and business models

- Connective intelligence and collective intelligence in organizational behavior
Transitions in Technologies

- Managing technological/organizational change and innovation

- Technology networks, technology transfer benefits and risks, technology acquisition and diffusion

- Smart technologies and development discontinuities, renewable sources and sustainability

- Digitalization, гот, гст, cybernetics, forecasting

- Technological traditions, strategic surprise and response systems

- Studies that promote understanding of the dynamics of socio-technical systems change

- Science and technology policy that fosters transformative advancement

- Modeling technological change in vucA (volatile, uncertain, complex, ambiguous) environments

SUBMISSIONS

The manuscripts should be submitted as e-mail attachment to the editorial office at mgt@fm-kp.si. Detailed guide for authors and publishing ethics statement are available at www.mgt.fm-kp.si.

\section{EDITORIAL OFFICE}

University of Primorska

Faculty of Management

Cankarjeva 5, 6104 Koper, Slovenia

mgt@fm-kp.si · www.mgt.fm-kp.si

PUBLISHED BY

University of Primorska Press

Titov trg 4, 6ooo Koper, Slovenia

zalozba@upr.si·www.hippocampus.si

Abstracts translated into Slovene

by Martina Paradiž and

Karin Podlipnik Bukovnik

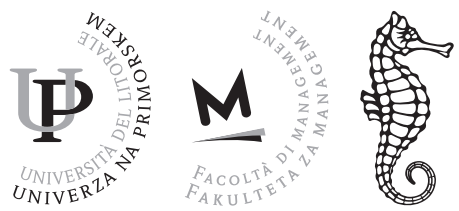




\title{
Initial Financing of Croatian sMEs: \\ Financial Reports Evidence
}

\author{
Roberta Kontošić Pamić \\ Juraj Dobrila University of Pula, Croatia \\ roberta.kontosic.pamic@unipu.hr \\ Adriana Galant \\ Juraj Dobrila University of Pula, Croatia \\ adriana.galant@unipu.hr
}

\begin{abstract}
When starting a business, one of the major decisions that need to be made is how such business will be financed. Entrepreneur can consider different possibilities, the most commonly used sources of financing include own resources of entrepreneur(s) and combination of own resource and borrowed resources. Due to legal requirements, in Croatia it is theoretically impossible to start a company without own resources, although it is possible to start a company with symbolical amount of own resources. For a new company it could be hard to lend money from financial institutions due to the lack of business experience and asset, which could serve as collateral. Considering different available ways of financing new business, the aim of this paper is to analyse how new established Croatian SMEs are financed. The conducted research has shown that new entrepreneurs are using more borrowed resources to finance their asset compared to own resources.
\end{abstract}

Key Words: entrepreneurship, financing, financial reports, smes, Croatia JEL Classification: L26, M 41

((c))BY-SA https://doi.org/10.26493/1854-6935.18.265-283

\section{Introduction}

Starting a business it is not an easy decision, it is a well-considered decision accompanied by risk taking, perceived market opportunity, good business idea and designed financial construction. It is not unusual that persons have fear of failure, but this fear can be also bigger and at the same time blocking, in particular if you come from a transition country as it is Croatia. In early nineties' of last century Croatia started its path to an open economy country carrying along the way the heritage from another system. So living and doing business in a relatively young democratic and market economy state can have it is own challenges. 
One of the things, which entrepreneurs think and rethink before starting a business it is initial financing. Such decision is very important since 'proper financial capital structure is crucial for obtaining better operational performance' (Burżacka 2017, 8). Entrepreneurs can choose to start their business with their own capital (equity), or with combination of own capital (equity) and debt. Not having own capital, entrepreneur is forced to be open for other financing possibilities. Smaller companies are faced with different challenges regarding the use of equity and/or debt financing, and often the decision to use one of this sources is driven by necessity rather than by choice (Coleman, Cotei, and Farhat 2016).

In line with Croatian legislation, it is impossible to start a business without own resources, with an exception of a newly introduced legal form in which subscribed capital is symbolic and encourages people to open something on their own. Therefore, depending of a legal form that entrepreneur choose to setup its business in Croatia, there are different amounts of subscribed capital, often not leaving them other choices than to borrow money from financial institutions, mostly banks. Being new and small on the market makes them hardly visible and uncertain, based on available assets to the key financial players. On the other hand, alternative financial sources are not so developed and spread at Croatian business scene.

In this paper, the aim is to analyse which source of financing is mostly used in Croatian new companies. Also, the authors perceiving the specifics of different industrial sectors will make the analyses between the major ones, regarding the mentioned topic.

This paper is composed of six sections which emphasis the small and medium enterprises sector in Croatia through conducted primary and secondary research. For primary research purposes, the authors used the companies' financial reports of active Croatian entities that were established during 2019. The conclusion of the paper brings possible way of business model transformation for new companies on Croatian market regarding the sources of initial financing.

\section{Research Background}

THEORETICAL BACKGROUND

In literature, different theories can be found to explain the debt-equity choice; however, there is no universal theory for explaining it (Myers 2001). Some of these theories include: trade-off theory, pecking order 
theory, free cash flow theory. The trade-off theory states that companies 'seek debt levels that balance the tax advantages of additional debt against the costs of possible financial distress' (Myers 2001, 81). However, due to little or no revenues generated in the first year of operation, new established companies are less likely to have advantages of using tax benefits (Coleman, Cotei, and Farhat 2016). According to the pecking order theory 'companies will borrow, rather than issuing equity, when internal cash flow is not sufficient to fund capital expenditures,' while free cash flow theory states that 'dangerously high debt levels will increase value, despite the threat of financial distress, when a firm's operating cash flow significantly exceeds its profitable investment opportunities' (Myers 2001, 81). According to Coleman Cotei, and Farhat $(2016,108)$, the pecking order theory is more suitable to 'explain why small firms tend to prefer equity to debt capital if external financing is required.' Evidently, each of these theories recommends different structure of financing sources (debt-equity).

One of the main characteristics of new established smes is that they are usually owner-managed. Due to that, they are more prone to issue external debt compared to external equity aiming to preserve both ownership and control (Coleman, Cotei, and Farhat 2016). Although, internal financing, when it is available, is preferred over external financing, companies limit future excess of slack as it constitutes a potential source of conflict (Gaud, Hoesli, and Bender 2007).

The most often emphasized benefit of using debt financing is related to tax deduction, since majority of world's countries allow deduction of payed interests on loans from the corporate tax base, while returns on equity typically do not have such benefit (Hebous and Ruf 2018). However, also equity financing has its benefits as well. When companies do not have obligation to return loans (principals and interest), managers have free cash flow to pursue other goals (Mande, Park, and Son 2012). There are also some other benefits of lower leverage ratio, including greater financial flexibility and higher prestige to the company (Hovakimian, Opler, and Titman 2001).

\section{DEFINING SMES IN EUROPE}

European Commission categorize small and medium enterprises (SMEs) sector in 3 categories by 3 criteria; number of employees, turnover and balance sheet. The size categories are from small, with less than $10 \mathrm{em}-$ ployees, turnover and balance sheet less than 2 million Euros. The next category includes small business from 10-50 employees and turnover and 
TABLE 1 SMES categories

\begin{tabular}{lrrr}
\hline Category & Employees & Turnover & Balance Sheet \\
\hline Micro & $0-10$ & $<€ 2$ million & $<€ 2$ million \\
Small & $10-50$ & $<€ 10$ million & $<€ 10$ million \\
Medium & $50-250$ & $<€ 50$ million & $<€ 43$ million \\
\hline
\end{tabular}

NOTES Adapted from European Commission (2020a).

balance sheet less than 10 million Euros. The category with the highest numbers in this sector are medium enterprises that employ between 50 and 250 employees, have a turnover less than 50 million Euros and balance sheet less than 43 million Euros (table 1).

Although it is possible to make differences among the SMES regarding their performances, all of them contribute to the development and rise of employment. Small and medium enterprises are seen as the major factor of economic development on different administrative levels - from regional to national (Feeney and Riding 1997) and further. Often are also mentioned the benefits on socio-economic development of this business sector (Cook and Nixson 2000).

SMES contribution to the development it is characterized through different advantages (Keskin et al. 2010) like that SMEs provide the strength of element of-balance income spectrum, they make decisions more quickly, they also boost private initiatives and compose an effective way to expand the manufacturing and industrialization to the whole country. Furthermore, sMEs are the manufacturer of intermediate goods and inputs of large industrial enterprises, they can be effective in increasing quality of life and from the financial point of view SMES possess a significant role to fulfil the function to reflect small and family savings directly to the investments.

In EU-28 there are 25 million SMES that employ 100 million people. Of these 25 million smes, $93 \%$ are micro businesses, while smes make $99.8 \%$ of all businesses in the EU-28 in the nonfinancial sector. The situation is similar in all Member Shares, where the share of micro sMEs is the largest, from 82 to $97.4 \%$ depending of country.

According to European Commission (2020b) small and medium enterprises gain more than half of Europe's GDP, add value in every sector of the economy, bring innovative solutions and spread them throughout Europe's regions. Also, they are seen central to the EU's twin transitions to a sustainable and digital economy, but also essential to Europe's compet- 
itiveness and prosperity, economic and technological sovereignty. Small and medium enterprises are resilient to external shocks and in the European Union's industrial strategy are core parts of its achievement (European Commission 2020b). In 2018, that is last reported year, micro business had the majority of the impact in increase of value added and employment, so it is the change in SMEs size classes (European Commission 2019).

\section{SMES IN CROATIA}

In Croatia smes sector is defined through 2 different legislation frames; the Accounting Act which regulates and classifies entrepreneurs and groups of entrepreneurs ('Zakon o računovodstvu' 2020) and Small Business Development Promotion Act. According to Small Business Development Promotion Act the small and medium economy sector is presented by physical and legal persons who independently and permanently perform permitted activities for the purpose of making a profit or income on the market ('Zakon o poticanju razvoja malog gospodarstva' 2016).

These two acts recognize same categories with the exception of large entities that are not included in The Small Business Development Promotion Act. The criteria for classification the size category in these two acts are also same, only the numerical values for them differ. The Small Business Development Promotion Act follows the European criteria, but in this paper authors followed the criteria defined by Croatia Accounting Act as the research methodology is based on accounting perspective.

The Accounting Act recognizes 4 categories of businesses in the SMES sector; micro, small medium and large enterprises selected by amount of total assets, amount of income and number of employees. The micro enterprises are those with less than 10 employees, with the income up to 639,333.0o Euros and the amount of total assets up to 346,666.oo Euros. The other two categories are small enterprises, with less than 50 employees, amount of income up to 8,000,000.00 Euros and medium enterprises with less than 250 employees, with the income up to 40,000,000.00 Euros and the amount of total assets up to 20,000,000.00 Euros. The large enterprises are those that show larger amounts in at least 2 categories regarding the medium enterprises (table 2).

As the important part of Croatian development, the number of micro and small enterprises has been growing in the last 5 years, together with the SMES sector, although the percentage of this sector in the total number of enterprises in Croatia is constant 99.7\% (Singer et al. 2019). Increase 
TABle 2 Classification of Enterprises in Croatia According the Accounting Act

\begin{tabular}{lrrr}
\hline Type & Amount of total assets & Amount of income & Number of employees \\
\hline Micro & $€ 346,666$ & $€ 693,333$ & 10 \\
Small & $€ 4,000,000$ & $€ 8,000,000$ & 50 \\
Medium & $€ 20,000,000$ & $€ 40,000,000$ & 250 \\
Large & Entrepreneurs who exceed boundary indicators in at least two of the three \\
& conditions from the definition of medium entrepreneurs & \\
\hline
\end{tabular}

Notes Adapted from 'Zakon o računovodstvu' (2020).

in SMES sector influenced the rise of employment from 422,238 in 2014 to 494,211 in 2018 which was followed by increase in total income and rise of total income per employee from 511,103 in 2014 to 556,159 in 2018. On the other hand, average number of employees has decreased through the years showing the tendency of entrepreneurial activity in which is employed 3.8 employees.

The number of medium enterprises has been rising like the number of small and micro enterprises though is smaller because the percentage of medium enterprises in SMES sector is smallest regarding the size category. Indicators as number of employees in medium enterprises, total income, total income per employee have been rising from 2014 to 2018 . Only the average number of employees has varied.

Entering in business with a product or service can have different starting points, that is, enterprises can enter at the market with new product or the one that is already familiar to them. In Croatia, the innovation is something that should be more in focus in the next period, as the entrepreneurs are not innovative and they don't offer new products to the market.

Croatian government has for years been looking on the SMES sector as a strategic point in economic development. The Strategy of Entrepreneurial Development in Croatia 2013-2020 (Ministry of Entrepreneurship and Crafts 2013) introduced 5 strategic goals which will enhance Croatian entrepreneurial potential, entrepreneurial environment, competitiveness of the sector. The goals are harmonized with those of European Commission and are focused on improvement of economic performance of small businesses in manufacturing and service sectors by investing in $\mathrm{R} \& \mathrm{D}$, boosting innovation, export and business networks. The Strategy aimed to improve access to finance developing a variety of financial opportunities for small business entities and closing the financial gap 
for retail economy. The strategic goal to promote entrepreneurship is visible through the law which was introduced in 2013 and edits the categories and roles of entrepreneurial infrastructure as the way to balance the interregional development, followed by boosting entrepreneurial skills by supporting the lifelong learning and enhancement of entrepreneurial environment which was burdened by administrative procedures.

Different entrepreneurial infrastructure have been defined by the Law on Entrepreneurial Infrastructure Improvement ('Zakon u unapređenju poduzetničke infrastrukutre' 2018), helping the establishment and development of businesses but also their environment with a significant impact on entrepreneurial activity. TEA index in Croatia has improved through the years and in the last monitored year has been bigger than $\mathrm{EU}$ average (Singer et al. 2019); Croatian 9.6 versus 7.6 E $\mathrm{E}$. The reason of entering in business for most of Croatian is still seen opportunity at the market (TE A Opportunity 6), so it's an index greater than EU average (5.7) but smaller than GEM average (8-9). Due to economic situation and long term unemployment in Croatia, some people have no choice, than to start something on their own. This is the reason why the TEA Necessity index for Croatia (3.1) is double than EU average (1.4), though is equal to GEM average (3.1). For the complexity of entrepreneurial environment and climate in Croatia the motivational index (1.9) is lower than EU average (2.3) and GEM average.

No matter the reason or the height of motivation, for starting a company in Croatia there are multiple options defined by the different criteria and different amount of subscribed capital defined by the law. Starting the most common business in Croatia owned by one or multiple persons, limited liability company (in Croatian: društvo s ograničenom odgovornošću - d.o.o.) is possible with start-up capital of 20,000 HRK $(2,660$ Euros). A type which is relatively newly introduced is simple limited liability company (jednostavno društvo ograničene odgovornosti - j.d.o.o.) that has the smallest amount of startup capital $10 \mathrm{HRK}$ (1.3 EUR). The biggest start-up capital of 200,000 HRK (27,000 EUR) as lowest amount of shared capital, is for joint-stock companies.

\section{FINANCING SMES}

When starting the business in the absence of enough own money, the possibilities are to borrowed it from family and friends as the most common financial source (Hisrich, Peters, and Shepard 2008). Also, some of startups can decide to borrow money from banks, search for alternative source 


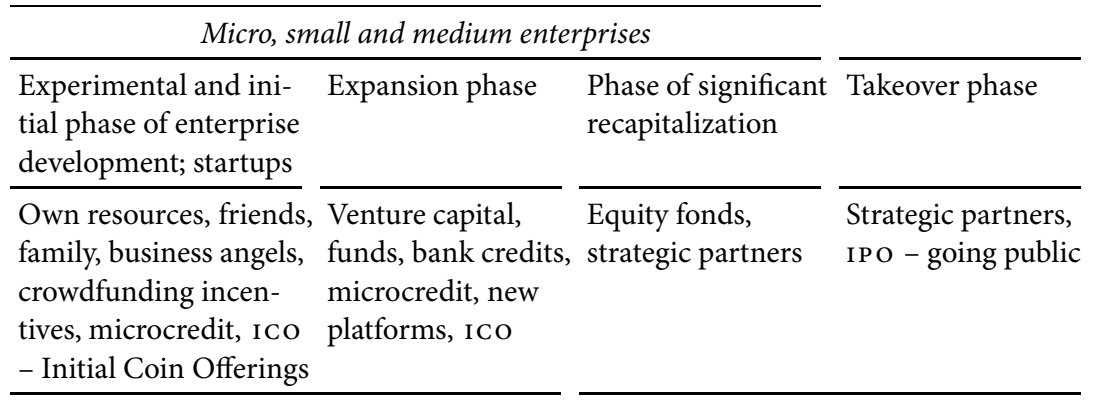

Large enterprises

FIGURE 1 Sources of Financing and Enterprise Development Cycle (adapted from Croatian Bank Association 2018)

of financing or apply for different kind of supports. The hardest thing to SMES, which governments have recognized, is to be financed by external sources because of the lack of collaterals, the presence of greater information asymmetry with investors and insufficient cash flows (Schwienbacher and Larralde 2010).

In Croatia, the traditional sources of financing are the most important ones, such as: own sources of financing, loans and financial leasing (Croatian Banking Association 2018). On the other hand, the sources that could help in the initial phase and become common in other countries such as venture capital funds, business angels or crowdfunding platforms are still underdevelopment, leaving not so many choices to enterprises in their earliest phases. As figure 1 shows in the experimental and initial phase of enterprise development SMEs sector use own resources, friends, family and also the non-traditional sources. The types of financing sources are different in stages that follow. From accounting perspective resources are divided as own resources (capital and reserves) and barrowed resources (liabilities). The own resources are capital from entrepreneurs, their family and friends, business angels, crowdfunding, etc., while borrowed capital (liabilities) are loans and credits from financial institutions and other borrowers, suppliers, etc. As mentioned before, the research is made by accounting point of view so these are terms that authors will use.

\section{Methodology and the Results}

RESEARCH SAMPLE

Taking into account the aim of this paper, i.e. determining how new established entrepreneurs in Croatia are financed, the research sample in- 
TAB BE 3 Representative Sample Size

\begin{tabular}{lr}
\hline Accepted margin of error & $10 \%$ \\
Confidence level & $95 \%$ \\
Population size & 6.688 \\
Response distribution & $50 \%$ \\
Recommended sample size & 95 \\
\hline
\end{tabular}

NOTES According to Raosoft (2004).

cluded entrepreneurs in initial phase of development. More precisely, active entrepreneurs established during the year 2019 (the latest year for which the financial data are available) were included. In an attempt to exclude entrepreneurs without business activity, only entrepreneurs with one or more employees were considered.

Based on data from Croatian Chamber of Commerce there were in total 6,689 entrepreneurs established in year 2019 that met the following conditions: (1) active entrepreneurs, (2) submitted annual financial statements for year 2019, and (3) one or more employees. Out of this total number of new established entrepreneurs only one is large sized, meaning there were 6,688 new established entrepreneurs from group sMEs. Regarding the legal form of considered new SMES, 3,550 entrepreneurs were established as simple limited liability company (j.d.o.o.), 3,078 entrepreneurs were established as limited liability company (d.o.o.), 2 as joint-stock company (d.d.) and 58 entrepreneurs were established in other legal form (see https://digitalnakomora.hr).

For purposes of this research the sample of 100 SMEs established in year 2019 was included. Considering the whole population of 6,688 entrepreneurs meeting previously defined criteria, the representative sample size should comprise all least 95 entities with $95 \%$ level of confidence (table 3).

Data were collected from entrepreneurs' financial statements for year 2019 through the service of Financial Agency (FINA) during September, October and November 2020. As criteria for selecting 100 SMEs from the population, the value of total revenues was used. Therefore, 100 new established SMEs with highest total revenues were included. However, due to missing data, two companies were skipped, and replaced with subsequent entrepreneurs. Entrepreneurs from all industry sectors were considered. The descriptive statistics of data used in this research are presented in table 4 . 
TABLE 4 Descriptive Statistics (in 1000 HRK)

\begin{tabular}{lrrrrrr}
\hline Item & $N$ & Mean & Min & Max & Median & Std. dev. \\
\hline Total asset & 100 & 8,035 & 23 & 59,282 & 3,565 & 10,934 \\
Subscribed capital & 100 & 777 & 0.010 & 22,572 & 20 & 3,413 \\
Capital and reserves & 100 & 1,744 & $-21,996$ & 23,713 & 570 & 5,441 \\
Liabilities & 100 & 6,222 & 26 & 48,994 & 2,441 & 9,120 \\
Long term liabilities & 100 & 1,011 & 0 & 29,583 & 0 & 3,524 \\
Short term liabilities & 100 & 5,211 & 26,421 & 48,994 & 2,257 & 8,221 \\
\hline
\end{tabular}

As evident from previous table, differences between included smes are evident. Regarding the size of the entrepreneurs, measured with total asset, it ranges from 23,802 till more than 59 million, with mean value of 8.03 millions of HRK. The value of capital and reserves (own resources) ranges from -22.00 million till 23.7 million, with mean value of 1.7 million HRK. The minimal value of capital and reserves is negative, indicating that some entrepreneurs have larger value of liabilities than total asset (and negative position of capital and reserves). Such situation is reported for 9 out of 100 included entrepreneurs ( $9 \%)$. As for value of total liabilities, it ranges from $26,421 \mathrm{HRK}$ to 48.99 million $\mathrm{HRK}$, with average value of 6.22 million HRK. From the structure of liabilities, it can be seen that in average short term liabilities are higher than long time liabilities. Moreover, for 66 entrepreneurs no value of long term liabilities has been reported. Therefore, companies are mostly using borrowed resources to finance operational activities, and not for purposes of investments.

The values of subscribed capital are ranging from $10.00 \mathrm{HRK}$ to 22.57 million HRK, with mean value 0.78 million HRK. There are only 4 entrepreneurs in the sample established as simple limited liability company (j.d.o.o.) which have subscribed capital lower that $20.000 \mathrm{HRK}$ (minimal subscribed capital for limited liability company). Evidently, entrepreneurs are more prone to start their business as classic limited liability company with minimal subscribed capital of $20,000 \mathrm{HRK}$. Indeed, majority of entrepreneurs start their venture with minimal value of subscribed capital. Out of total number of entrepreneurs included into sample 76 of them are established with minimal value of subscribed capital (20,000 HRK).

From these descriptive statistics it is already evident that entrepreneurs are using more borrowed sources compared to own sources of financing (higher mean value of liabilities than capital and reserves). 
TAB LE 5 Research Results for Structure of Financing New Established Enterprises in Croatia

\begin{tabular}{lrrrrrr}
\hline Item & $N$ & Mean & Min & Max & Median & Std. dev. \\
\hline Self-financing ratio & 100 & 0.1702 & -8.8425 & 0.9589 & 0.2108 & 0.9907 \\
Leverage ratio & 100 & 0.8298 & 0.0411 & 9.8425 & 0.7892 & 0.9907 \\
\% of subscribed capital & 100 & $5.54 \%$ & $0.00 \%$ & $84.03 \%$ & $0.73 \%$ & 16.2643 \\
in total asset & & & & & & \\
\hline
\end{tabular}

\section{RESEARCH RESULTS}

In order to provide answers on defined research question regarding the structure of financing new established entrepreneurs, data from financial statements have been used. From accounting point of view, own resources include balance sheet position of Capital and reserves, while borrowed resources include position of Liabilities (Long term and Short term liabilities). These values have been put in relation with total asset in order to get information about the proportion of entrepreneurs' asset financed from own and from borrowed resources. Therefore, the following indicators have been calculated and analysed: Self-financing ratio (calculated as ratio between Capital and reserves and Total asset) and Leverage ratio (calculated as ratio between Liabilities and Total asset). Additionally, the ratio between subscribed capital and total asset has been calculated in order to identify how much of entrepreneurs' asset is financed from subscribed capital invested from owners. Table 5 contains the results of the analysis.

As evident from the previous table new established entrepreneurs are dominantly using borrowed resources for financing their asset. In average, $83 \%$ of total asset is financed from liabilities (borrowed resources), while only $17 \%$ of total asset is financed from Capital and reserves (own resources). Therefore, majority of asset, in average, is financed from borrowed resources that need to be returned to their owners in future. The minimum value of self-financing ratio is negative $(-8.8425)$ and this is situation where enterprises are reporting negative position of Capital and reserves in their Balance sheet (liabilities higher than total asset). The maximum calculated value of self-financing ratio is 0.9589 indicating that in this enterprise $95.9 \%$ of total asset is financed from own resources. The company with highest value of Self-financing ration, at the same time is exhibiting the lowest value of Leverage ratio (o.0411), indicating that the rest of this enterprises' total asset $(4.11 \%)$ is financed from borrowed re- 
TA B LE 6 Research Results for Structure of Financing New Established Enterprises in Croatia for Leading Industry Sectors

\begin{tabular}{|c|c|c|c|c|c|c|c|c|c|c|}
\hline & \multirow[t]{2}{*}{$N$} & \multicolumn{3}{|c|}{ Self-financing ratio } & \multicolumn{3}{|c|}{ Leverage ratio } & \multicolumn{3}{|c|}{ Percentage $^{*}$} \\
\hline & & Mean & Min & Max & Mean & Min & Max & Mean & Min & Max \\
\hline (1) & 38 & -0.017 & -8.843 & 0.769 & 1.017 & 0.231 & 9.843 & 4.37 & 0.00 & 81.73 \\
\hline (2) & 21 & 0.348 & -0.141 & 0 & 0.652 & 0.041 & 1 & 5.69 & 0.06 & 81.43 \\
\hline (3) & 14 & 0.337 & 0.002 & 0.651 & 0.663 & 0.349 & 0.998 & 0.86 & 0.02 & 3.17 \\
\hline (4) & 8 & 0.368 & 0.074 & 0.868 & 0.632 & 2 & o. & 2.20 & 0.19 & 12.21 \\
\hline (5) & 7 & -0.063 & -2.534 & 0.764 & 1.063 & 0.237 & 3.534 & 9.14 & 0.06 & 59.55 \\
\hline (6) & 12 & 0.261 & -0.110 & 0.804 & 0.739 & 0.196 & 1.110 & 14.61 & 0.04 & 84.03 \\
\hline
\end{tabular}

NOTES Row headings are as follows: (1) wholesale and retail trade; repair of motor vehicles and motorcycle, (2) manufacturing, (3) construction, (4) transportation and storage, (5) accommodation and food service activities, (6) other sectors. ${ }^{\star}$ Of subscribed capital in total asset.

sources. The maximum calculated value of leverage ratio is 9.8425 (higher than 1) indicating that total liabilities are higher than total asset. Enterprises reporting higher values of total liabilities than total asset could experience significant financial problems since even if all of its asset would be sold it would not be enough to pay off all liabilities.

The indicator percentage of subscribed capital in total asset indicates that, in average, enterprises are financing only $5.54 \%$ of their asset from subscribed capital. The minimum reported values for this indicator is $0.00 \%$, while the highest value is $84.03 \%$.

\section{STRUCTURE OF FINANCING NEW ESTABLISHED ENTERPRISES IN CROATIA BY INDUSTRY SECTORS}

In addition to analysing the financing source structure for all set of companies included into research, a more detail analysis financing source structure for leading industry sectors has been performed. The results are presented in table 6 .

As can be seen from previous table, the most favourable structure of financing resources is within Transportation and storage (Sector $\mathrm{H}$ ) where in average $37 \%$ of asset is financed from own resources, and $63 \%$ from borrowed resources. Just a little less favourable results are reported for Manufacturing sector (Sector C) where in average 35\% of total asset is financed from own resources, and 65\% from borrowed resources and for Construction sector (sector F), where $34 \%$ of total asset is financed from own resources, and $66 \%$ from borrowed resources. At least favourable sit- 
uation is reported for Accommodation and food services activities (Sector I), where self-financing ratio has the lowest average value, and the highest leverage ratio. In average, within this sector the value of liabilities is higher than total asset. The average value of self-financing indicator is negative also for new entrepreneurs established within the biggest industry sector, i.e. sector of wholesale and retail trade; repair of motor vehicles and motorcycle (Sector G).

\section{Discussion and Conclusion}

The decision to start a new business adventure is not easy and a lot of different factors need to be taken into account. One of the major decision that entrepreneur needs to make is how to finance its new business. There are different possibilities which entrepreneurs can consider when starting a business, such as using their own resources and resources from their friends and family, collecting money using crowdfunding, alliance with business angels, lend money from financial institutions or other creditors, etc. From accounting point of view, different sources of financing can be grouped into two categories: capital and reserves (own resources) and liabilities (borrowed resources). Sources of financing entrepreneurs' asset are presented in balance sheet which entrepreneurs are obligated to prepare on annual basis.

The main aim of this research was to explore how new established entrepreneurs are financed. The research was conducted on a sample of 100 active Croatian entrepreneurs that were established during year 2019. The financing structure was analysed based on data from financial reports (balance sheet) for year 2019. Based on collected data an attempt to provide answer whether Croatian new established entrepreneurs are more using own or borrowed resources to finance their new established business. Majority of new established business start as micro or small enterprise, and grow as their business activities are spread and more developed. Because of that, in focus of this research will be new established sMEs.

New business can be established in different legal form, including limited liability company, simple limited liability company, publicly listed company, etc. Depending on the chosen legal form, different amount of minimal required subscribed capital is required by the law (10 HRK for simple limited liability company, 20,000 H RK for limited liability company and 200,000 HRK for publicly listed company). Based on entire population of new established entrepreneurs in 2019, simple limited liability companies and limited liability companies are mostly used form to 
start a new business. However, when considered only 100 biggest new entrepreneurs (in terms of total revenues), limited liability companies dominate and there are only few entrepreneurs established as simple limited liability enterprise. Research has shown that majority of new entrepreneurs are set up with minimal required amount of subscribed capital what results with low level of creditors protection and increased exposure to larger set of risks.

The research results have also shown that using borrowed resources (liabilities) dominate as a source of financing asset. Moreover, in average majority of new entrepreneurs $(82.3 \%)$ are financed from borrowed resources (liabilities). Considering security of doing business, such indicators point out to potential problems with continuation of business operations in the future. Entrepreneurs will be obligated to pay off barrowed money and it is questionable if they will have enough liquid assets to do so. The optimal solution for this situation is to increase own resources by additional capital payment by the owners (or including additional owner(s)). Additionally, some entrepreneurs have self-financing ratio negative and leverage ratio higher than one, indicating that total liabilities are higher than total asset. These entrepreneurs are in greater risk of bankruptcy, and decisions regarding future operations should be made. If entrepreneur expects that in following years it will generate profit, these future profits can be used to cover the loss generated in first year of doing business. Additionally, entrepreneurs in these situations can also increase the value of subscribed capital.

As it has been shown, in average entrepreneurs' liabilities are higher than capital and reserves. Another potential problem that has been identified is related to the structure of these liabilities. Majority of these liabilities are short-term liabilities which are primary result of acquiring resources for production or providing services, including accounts payables, taxes payables, liabilities toward employees, etc. Such situation indicates that entrepreneurs have problems with financing every day's business operations.

Obtained results are in line with the ones obtained by Robb and Robinson (2014) who found that those companies in their start-up phase rely more on external debt sources and less on friends and family-based sources. However, there are also studies that identified opposed results. For example, Cotei and Farhat (2017) found that entrepreneurs in their start-up phase mostly rely on initial insider capital sources.

A research that involved 8,000 small and medium enterprises in 
United Kingdom, showed that majority of high growth SMEs rely strongly on debt-based finance for their funding (Brown and Lee 2019). In Australia, $46 \%$ of smes are interested in equity funding (Dwyer, Duncan, and Southam 2020). Comparative analyses of two countries United Kingdom and China showed how types of financing change during the company life cycle. Regarding initial funding big percentage of included companies relied exclusively on financial support from their immediate family (Hussain et al. 2006). As the research followed the companies for 5 years, the same one showed that after 2 years in business, they higher rely on own savings and the financial support of bank and other financial institutions than family. At the end of five years of business continuity, most of the companies in the UK sample relied for their borrowing needs primarily on financial institutions and to a lesser extent upon their own savings. On the other hand, China's companies depended mainly upon financial support from their immediate family and to a smaller extent on financial institutions.

From all presented results, it can be seen that new entrepreneurs are facing certain problems related to financing their asset. This situation could be improved by promoting and providing asses to own resources. Firstly, entrepreneurs could join their capital (own resources) and start joint ventures and in such a way own resources would be higher and risks reduced, but also divided. Next opportunity is alliance with business angels. Entrepreneurs could start their new business with the support of business angels, which could contribute with financial equity and be a partner in new business. There is also possibility of using equity based crowdfunding which is a great opportunity for new business. Equity based crowdfunding or crowdinvesting represents 'a financing method for young ventures and other commercial projects that supports the acquisition of equity by coordinating the submission of different forms of shares to an undefined group of possible investors through social virtual communities' (Hagedorn and Pinkwart 2016, 72). However, the use of equity based crowdfunding may be limited with the availability of crowdfunding platforms for some country, but also with regulation of doing business in certain country. Croatia, as a relatively young country, doesn't have such developed scene of alternative, non-traditional sources of financing. On the other hand, this is something that is more connected with high tech companies that grow and develop fast. So, thinking about it should be limited by branch in which a new business in established. But, as the need for more available financial sources emerges, there should be 
initiatives to make a transition to a business ecosystem that is boosting innovation, with a synergy of different actors. The difference could happen introducing to the ecosystem universities as an active part of the puzzle with a high potential of contribution to the creativity and orientation to innovation of the youth. Developing ecosystem could contribute to better results of doing business and lower level of indebtedness. Governments (national, regional and local) as a significant part of business ecosystem could boost the entrepreneurial potential, make the environment more business friendly, especially for new established enterprises.

Availability of entrepreneurial infrastructure, like business or technological incubators, could also facilitate doing business, but also reduce costs and liabilities of new business. In such a way, structure of financing resources could also be improved. With an existing Law on Entrepreneurial Infrastructure Improvement and Register of Croatian entrepreneurial infrastructure, there were made improvements regarding systematization, transparencies and utility of elements of entrepreneurial infrastructure that can facilitate business, not only in their early stages, but also after, when they are in need to transfer to a more wider space and make connections with other entities (example business zones). As a part of entrepreneurial infrastructure activities or different curricular and extracurricular programmes, entrepreneurial and financial education of entrepreneurs could also contribute to the improvement of business activities in some early stages of business.

So, by increasing the proportion of own resources (firstly learning how and why do it), the structure of financing sources would be improved and risks decreased. Additionally, entrepreneurs could also exhibit other financial benefits, like improved liquidity and/or profitability.

There are several contributions of this research. Firstly, the results have reveal that new established enterprises have high levels of leverage, i.e. they mostly rely on borrowed resources to finance their asset what could result with financial problems in the future. Secondly, research has shown that majority of new enterprises are established with minimum required amount of subscribed capital what leads to the problem of low level of creditors protections and raises question about capital adequacy of such companies.

Additionally, research has been conducted on a sample of smes operating in Croatia, a small, transitional country. Croatia is a country with limited experience in capitalism, and just thirty years ago has started the process of transition, what makes it interesting area for this research. On 
the other hand, this is also one of the limitations, the size of the country, which doesn't allow making general conclusions but can be a good starting position for further research, to compare Croatian situations with a similar neighbour country which has also been in transition cycles. Moreover, as during the operating years, some of company needs change, other possible direction for the future research could be to compare the same companies with the leg in time, to see if they are still profitable and liquid and if they have made the switch from initial financing sources to some other and how many of them.

To conclude, results of this research could be of interest for practitioners, but also for policy makers. Practitioners could get information how their competitors are financing their asset and to do benchmarking. Additionally, paper contains suggestions for improvements what could be of interest for practitioners. Policy makers could use results of this study as a base for improvement of current policies in order to make entire society more environmentally friendly, especially for new established business.

\section{Acknowledgments}

This paper is a result of scientific projects 'Organizational and Legal Challenges in the Modern Business Environment' and 'Accounting for the Future, Big Data and Economic Measurement' supported by the Faculty of Economics and Tourism 'Dr. Mijo Mirković, Juraj Dobrila University of Pula. Any opinions, findings, and conclusions or recommendations expressed in this paper are those of the author(s) and do not necessarily reflect the views of the Faculty of Economics and Tourism 'Dr. Mijo Mirković.'

\section{References}

Brown, R., and N. Lee. 2019. 'Strapped for Cash? Funding for U K High Growth smes since the Global Financial Crisis.' Journal of Business Research 99:37-45.

Burżacka, M. 2017. 'Building an Optimal Capital Structure of Start Ups.' Gospodarka w praktyce i teorii 3 (48): 7-17.

Coleman, S., C. Cotei, and J. Farhat. 2016. 'The Debt-Equity Financing Decisions of us Startup Firms.' Journal of Economics and Finance 40 (1): 105-26.

Cook, P., and F. Nixson. 200o. 'Finance and Small and Medium-Sized Enterprise Development.' Finance and Development Research Programme Working Paper Series 14, Institute for Development Policy and Management, University of Manchester, Manchester. 
Cotei, C., and J. Farhat. 2017. 'The Evolution of Financing Structure in U S Startups.' The Journal of Entrepreneurial Finance 19 (1). https:// digitalcommons.pepperdine.edu/jef/volig/iss1/4.

Croatian Banking Association. 2018. 'Financing Micro, Small and Medium Enterprises: Open Questions.' н в A Analyses 64, Croation Banking Association, Zagreb.

Dwyer, B., K. Duncan, and C. Southam. 2020. 'Small-Scale Private Equity: Demand versus Supply.' Accounting Research Journal 33 (2): 363-80.

European Commission. 2019. Annual Report on European SMES 2018/2019. Luxembourg: Publications Office of the European Union.

- 2020a. 'Entrepreneurship and Small and Medium-Sized Enterprises (smEs).' https://ec.europa.eu/growth/smes_en.

- 202ob. 'sme Definition.' https://ec.europa.eu/growth/smes/sme -definition_en.

Feeney, L. S., and A. L. Riding. 1997. 'Business Owners' Fundamental Trade Off: Finance and the Vicious Circle of Growth and Control.' Canadian Business Owner, November.

Gaud, P., M. Hoesli, and A. Bender. 2007. 'Debt-Equity Choice in Europe.' International Review of Financial Analysis 16 (3): 201-22.

Hagedorn, A., and A. Pinkwart. 2016. 'The Financing Process of EquityBased Crowdfunding: An Empirical Analysis.' In Crowdfunding in Europe: State of the Art in Theory and Practice, edited by D. Brüntje and O. Gajda, 71-85. Cham: Springer.

Hebous, S., and M. Ruf 2017. 'Evaluating the Effects of ACE Systems on Multinational Debt Financing and Investment.' Journal of Public Economics 156:131-49.

Hisrich, R. D., M. P. Peters, and D. A. Shepherd 2008. Entrepreneurship. New York: McGraw-Hill.

Hovakimian, A., T. Opler, and S. Titman. 2001. 'The Debt-Equity Choice.' Journal of Financial \& Quantitative Analysis 36 (1): 1-24

Hussain, J., C. Millman, and H. Matlay. 2006. 's ME Financing in the U K and in China: A Comparative Perspective.' Journal of Small Business and Enterprise Development 13 (4): 584-99.

Keskin, H., C. Senturk, O. Sungur, and H. Kiris. 2010. 'Importance of SMEs in Developing Economies.' Paper presented at the 2nd International Symposium on Sustainable Development, Sarajevo, 8-9 June.

Mande, V., Y. K. Park, and M. Son. 2012. 'Equity or Debt Financing: Does Good Corporate Governance Matter?' Corporate Governance: An International Review 20 (2): 195-211.

Ministry of Entrepreneurship and Crafts. 2013. Strategy of Entrepreneurial Development in Croatia 2013-2020. Zagreb: Croatian Government. 
Myers, S. C. 2001. 'Capital Structure.' The Journal of Economic Perspectives 15 (2): 81-102

Raosoft. 2004. 'Sample Size Calculator.' http://www.raosoft.com/samplesize .html.

Robb, A. M., and D. Robinson. 2014. 'The Capital Structure Decisions of New Firms.' The Review of Financial Studies 27 (1): 153-79.

Schwienbacher, A. and B. Larralde. 2010. Crowdfunding of Small Entrepreneurial Ventures: Handbook of Entrepreneurial Finance. Oxford: Oxford University Press.

Singer, S., N. Šarlija, S. Pfeifer and S. Oberman Peterka. 2019. What makes Croatia an (Non)Entrepreneurial Country? GEM Croatia 2018. Zagreb: CEPOR.

'Zakon o poticanju razvoja malog gospodarstva.' 2016. Zakon.hr. https:// www.zakon.hr/z/527.

'Zakon o računovodstvu.' 2020. Zakon.hr. https://www.zakon.hr/z/118.

'Zakon u unapređenju poduzetničke infrastrukutre'. 2018. Zakon.hr. https://www.zakon.hr/z/652. 



\section{Relationship between Municipal Governance and Assurance Quality}

Kgobalale N. Motubatse

Tshwane University of Technology, South Africa

motubatsekn@tut.ac.za

Collins C. Ngwakwe

University of Limpopo, South Africa

collins.ngwakwe@ul.ac.za

This paper examines the relationship between municipal governance quality and assurance quality. The paper's pertinence lies in the deteriorating state of municipal service delivery and the Auditor General South Africa's (2016) recurring reporting of poor financial management in the vast majority South Africa's municipalities. Hence, the objective of the paper is to analyse the relationship between municipal governance quality (with quality of performance reports as the proxy) and the municipal assurance quality (with financial statement quality as a proxy). Data was collected from the archives of the Auditor General's consolidated municipal audit reports for the $2016 / 2017$ and $2017 / 2018$ fiscal years. The data was subjected to quantitative analysis using the fixed and random effects panel data regression methods. Findings from the statistical analysis in both models show that the quality of performance reports is significantly related to the quality of assurance, with a $\mathrm{p}$ value of less than 0.05 . The findings suggest that real improvement in municipalities' public service delivery and financial management depends on the level of improvement in governance quality, and the latter requires that bureaucrats tackle the now perennial issue of poor governance quality. This paper offers practical and researchbased recommendations, most important of which is the need to implement quarterly quality-of-governance and assurance checks in the municipalities, thus avoiding the extended delays associated with the annual audit cycle. The second recommendation is for further research to examine the relationship between governance quality and assurance quality in the national government sphere, to determine the degree to which the challenges experienced are similar to those at the municipal level.

Key Words: financial statement, financial management, municipal governance, assurance report, performance report, service delivery JEL Classification: $\mathrm{H} 79, \mathrm{H} 83$

(c) BY-SA https://doi.org/10.26493/1854-6935.18.285-300 


\section{Introduction}

There is a growing recognition that the heart of good working relationships within and between municipal structures requires (and generates) good governance practices. Such relationships ought to be built on effective communication systems, monitoring systems and interactions within governance structures (Wong 2017). Meanwhile, municipal governance oversight has become an integral part of municipal administrations (Nealer 2009), and trust of governance structures should be built to ensure that accountability becomes a reality (Schmidt and Zakayo 2018). Jackson (2018) states that establishing effective and accountable governance structures and processes are at the core of building good municipal government. Although municipalities are complex institutions with a wide range of powers and duties, this paper addresses the important issue of knowing who the officials and role-players in municipalities are and understanding their duties and responsibilities. According to Ter Bogt (2018) councillors, mayors and other administrative functionaries in municipal structures are key to the successful implementation of controls in municipal governance. Grimmelikhuijsen and Feeney (2017) explain that municipal governance more often than not, is seen as the reviewing of the municipality's compliance with its own policies, rules and regulations, while Matovu (2018) states that the key role of municipal governance structures is to be conscious of and proactive about the state and implementation of municipal laws and regulations. Van der Jagt et al. (2017) state that these role players should have an understanding and appreciation of both budgets and financial information in order to provide insightful support. Guragain et al. (2017) further observe that effective working relationships within municipal authorities are a key aspect of effective municipal governance. However, it is unfortunate, but true that some key governance structures within municipalities conduct their oversight work without an appreciation or understanding of budgets and financial information, and with no formal interaction with each other. Hence, this paper investigates the role-players associated with municipal governance in South African municipalities. Davies (2009) states that good working relationships are the cornerstones of effective municipal governance. According to Nurudin et al. (2017) the strength of the state rests largely on its ability to implement good governance principles and this then helps in the building of good relationships (Davies 2009). According to Goddard (2005) establishing such professional relationships contributes to the achievement of good governance and accountability. 
Whiteoak (1996) observes that the responsibility to report on financial management and to audit management rests with internal and external assurance providers, and Motubatse (2016) observes that the strength of assurance and the quality of formal communications within an entity are mutually supportive. Despite the fact that assurance providers have a good level of understanding of the business environments in which they operate, poor coordination of work assignments and a lack of accountability among various assurance providers are still widespread.

Poor governance impacts negatively on both accountability and transparency (Chowdhury 2017). Porumbescu (2015) observes that local government structures should view transparency and accountability as means of connecting with their public/customers. According to Leck and Roberts (2015) those entrusted with municipal governance are the enablers of municipal administration. Natal'ya et al. (2016) state that the condition of municipal administration is reflected in the quality of the governance structures: if these are performing their roles effectively in supporting the administration, the administration will be similarly effective and efficient. For example, if governance structures such as audit committees and public accounts committees are able to achieve an improved and improving level accountability in key assurance providers (Degeling, Anderson, and Guthrie 1996), this is usually because they understand how assurance providers perform their work in local municipalities (Davies 2009).

Therefore, the objective of this paper is to examine the relationship between municipal governance and the quality of assurance the municipality is provided. Hence, the research question is whether a significant relationship exists between the quality of municipal governance and the quality of assurance the municipality receives.

The rest of the paper is organized as follows: the next section presents a literature review covering the diverse concepts addressed in this paper. Thereafter, the research method and the results are presented. The final section of the paper presents the conclusion and identifies some issues requiring further research.

\section{Literature Review}

\section{GOOD GOVERNANCE}

In many respects, good governance will eventually improve relationships between governance structures and municipal service delivery structures, and create a workable environment thus enabling municipalities to achieve their service delivery targets. However, good governance is 
not only important for the smooth-functioning of municipalities, it is also important for the public as well. To begin with, good municipal governance improves the public's confidence in the municipality. According to Rotberg (2014), good governance means efficient performance and delivery of positive results, and good governance codes usually end with a list of agreed public values (De Graaf and Paanakker 2015). Of particular interest in this respect is the role of local councillors. As elected representatives, councillors embody the commitment of authorities towards the public (Aars and Fimreite 2005). Cash (2016) explains that good governance is essentially the equitable, sustainable and efficient use of resource. According to Leitão, Alves, and Pereira (2016) good governance includes the right to participate in the process of agenda-setting and in decisionmaking. De Roo (2017) also contends that participatory decision-making and shared governance processes should be the cornerstone of good governance. This need (and often leads to) open, innovative governance structures, and transparency in municipalities' affairs (Leitão, Alves, and Pereira 2016).

\section{MUNICIPAL PUBLIC ACCOUNTS COMMITTEE}

Prior research has generally examined the roles fulfilled by public accounts committees in public and government sector entities. Degeling, Anderson, and Guthrie (1996) record that research into public accounts committees in Australia, as elsewhere, usually discuss and assess their contributions in terms of effectiveness in holding ministers and their departments accountable to Parliament, whereas Gilchrist and Coulson (2015) find that public accounts committees' work compliments the work of the Auditor-General by following up on issues reported with respect to performance information and financial management. Pelizzo and Kinyondo 2014) investigated the statutory roles of public accounts committees in Eastern and Southern African states, and found that the committees all have the power or authority to examine accounts and financial affairs.

Chohan and Jocobs (2016) examine how an institution's public accounts committee fulfils two important roles: first, it assists in the oversight of the budget preparation process; and second, it supports coordination efforts among key accountability institutions, such as the public accounts committee and the Auditor-General, in their fiscal oversight roles. Chohan and Jocobs (2016) also found that the budget preparation and monitoring process fits very well into the committee's commit- 
ment to enhancing accountability of constitutionally established entities by strengthening these institutions. Thus, the public accounts committee is usually recognised to be at the centre of financial accountability (Degeling, Anderson, and Guthrie 1996). In a study of public accounts committees in Eastern Africa, Pelizzo and Kinyondo (2014) also validate the ideal that the committee has the potential to promote good governance, curb corruption and to increase the trust of citizens, by exercising their unrestricted rights (and obligations) to examine the economy, and the efficiency and effectiveness of policy implementation.

Moreover, the public accounts committee plays a key role in public sector accountability, and by its very nature its role is as a public spending watchdog. Within the South African municipal context, the public accounts committee is established in terms of section 79 of the Municipal Structure Act (Republic of South Africa 1998), and its key activities include oversight and interrogation of any unauthorized, irregular or fruitless and wasteful expenditure by the council, the executive mayor, executive committee or any politically appointed office bearer of the municipality (National Treasury 2006). Just as Khalo (2013, 593) affirms, the committee's function is also to restores public trust. National Treasury (2006) records that public accounts committees have a role to play in improving governance through holding local governments accountable. This can be achieved through performance monitoring, and determining the effectiveness and efficiency of service delivery efforts. As Gilchrist and Coulson (2015) conclude, the relationship between the Auditor-General and the public accounts committees should be strengthened so that when the Auditor-General provides them with reports the committees in fact do follow up, assessing the extent to which the Auditor-General's recommendations have been carried through into the day-to-day work of the executive.

\section{AUDIT COMMITTEE}

According to Beasley et al. (2009) audit committees play a key role in assisting the board to fulfil its corporate governance and oversight responsibilities with respect to a company's financial reporting, internal control systems, risk management systems and the internal and external audit functions. Gendron (2009) states that audit committees should be strong advocates of good governance, and should actively support the work of the entity's auditors (DeZoort, Hermanson, and Houston 2003). He et al. (2017), for example, examine whether social ties between en- 
gagement auditors and audit committee members shape audit outcomes in a predictable manner. They found that social ties between engagement auditors and audit committee members do impair audit quality. Their results show that where social ties are more prominent, governance is relatively poor and agency conflicts are more severe. Fiolleau et al. (2019) and Hoang and Pomeroy (2019) also investigate the influence of the audit committee's oversight approach on the auditors' communications to the audit committee, and their study reveals that the auditor's communication with the audit committee has the ability to build the committee's willingness to rely on the auditor's report. On the other hand, Kamarudin et al. (2018) also examine the relationships between corporate governance (focusing on chairman duality, audit committee size, independence, and frequency of meetings, and on-time financial reporting. Their study found that firms whose financial statements are released on time are more likely to have larger audit committees which have a lower proportion of independent non-executive directors; in addition, these audit committees meet less frequently, and the entities are audited by industry specialist auditors. Kamarudin et al. (2018) also found that audit committees in municipalities are being used by councils as sounding boards with respect to understanding financial information.

\section{MUNICIPAL MANAGER}

In a recent study, Connolly (2016) assesses the impact of local politics on the principal-agent relationship between the council and its manager in the municipal government arena. In terms of South African legislation such assessment serves as an important role in the initial creation of an agency relationship within the municipalities' hierarchies (National Treasury 2006). Nelson and Svara (2015) remind us that the municipal managers form part of the (sometimes fraught) political/administrative relationship. Mahdavian, Mirabi, and Haghshenas (2014) examined the impact municipal managers' strategic thinking has on the functioning of a municipality, and found that they are fundamentally important to the achievement of improvements in the performance of the municipality. However, Siegel (2015) expresses his concern that the work of municipal managers is almost always overlooked, not well understood and mostly over-shadowed by the activities of the councillors. Thus, the things that work well from the perspective of the municipal manager's office are invisible from the public's perspective (Siegel 2015).

Hirsch, Nitzl, and Schauß (2015) studied the influence of management 
accounting departments within German municipal administrations over 743 municipalities in total. The study revealed that an effective management accounting department can only exert a positive effect when the municipal administration employs an accrual accounting regime. Examining another metric, George, Desmidt, and De Moyer (2016) surveyed 89 municipalities in Flemish speaking Belgium, and found that strategic planning improves decision quality if both top policy-makers and municipal managers are involved. Thus, the earlier the municipal manager is involved (as the person/office who is responsible for implementation of council policies) the better the outcomes.

In South Africa, the municipal manager is accountable to the council for implementing specific agreed outputs, and for the overall administration of the municipality. The municipal manager reports directly to the executive mayor and indirectly, through the mayor, to council (National Treasury 2006, 9-10). According to Dweba (2017), the municipal manager is part of the leadership team tasked with implementing municipal strategies. Liao (2018) recognises that the municipal manager is responsible for that public body's responsiveness to citizens' demands, and for the effective administration of the municipality. Thus, the municipal manager is accountable for the municipality's income and expenditure, and the management of its assets; in addition, the manager must also fulfil other obligations such as ensuring compliance with all legislation applicable to municipalities. On top of this list of duties, this position is viewed as a valuable source of support and assistance to councillors in their efforts to make informed decisions.

\section{MAYOR}

Egner et al. (2018) state that the mayor has substantial influence over the governance parameters adopted by the municipality. According to Bobonis, Cámara Fuertes, and Schwabe (2016), a mayor governs the municipality from political point of view. The mayor enjoys significant discretionary power over the budget allocations of this local government sphere (Bobonis, Cámara Fuertes, and Schwabe 2016). The mayor is also expected to oversee the municipal manager's office, ensuring that he is indeed delivering on the mandate of council, and that the agreed outputs are being achieved with the appropriate use of allocated resources (National Treasury 2006, 20). Steyvers et al. (2006) observe that the mayor functions as a pivotal player in the governance efforts of municipalities. Thus, the mayor requires great leadership and negotiating skills and expertise 
to encourage all municipal councillors to work together in the interests of the municipality; additionally the mayor must also be able to provide guidance and support to efforts to resolve disputes.

\section{MUNICIPAL COUNCIL}

Maserumule (2008) recognises that municipal councillors, as members of council committees, contribute to the effective operation of this the local government sphere, and to municipal administration. As recognised by Meloche and Kilfoil (2017), municipal councillors are elected officials serving in the local government structures. Thus, the council holds the mayor responsible for achieving promised outcomes and the municipal manager for specific outputs. The Municipal Finance Management Act (MFMA) and other legislation require municipal councils to be open and transparent in the performance of their duties and deliberations, and to encourage the involvement of the local community in municipal affairs (National Treasury 2006, 13). The municipal council is the highest governing body of a municipality. The members of the council make all the major decisions affecting the municipality. This includes decisions on education, the bylaws regarding construction of new buildings, or local tax levels. Within their responsibility for the municipality's financial affairs, they have powers to pass by-laws, approve budgets and to increase municipal service fees (National Treasury 2006). According to Maserumule (2008) these councillors are expected to have the requisite knowledge to perform the specific functions associated with their office.

\section{Research Method}

Data for the research and subsequent analysis described in this article was collected from the 2016/2017 and 2017/2018 consolidated general reports on the local government audit outcomes of the Auditor General South Africa, and is required in terms of the Municipal Finance Management Act (MFMA). The data covered audit outcomes for the municipalities in all nine provinces of South Africa for the two most recently concluded financial years. The volume of data suggested it was pertinent to apply a cross sectional panel data approach, comparing outcomes from two methods of panel data regression, namely the fixed effect and random effect methods (table 1 and table 2). The motivation for using these specific data sets (the two financial years 2016/2017 and 2017/2018) arises from the AGSA's 2015 mandate to strengthen the level of governance. In his 2014/2015 municipal audit report, the AGS A lamented that governance 
quality had declined and that this had contributed to the low level of service delivery in many provinces of the country. He implored municipal leaders to ensure the restoration of good governance practices in subsequent fiscal years (Auditor-General South Africa 2016).

In the following analysis, governance quality is represented by the quality of municipal performance reports; and since, according to PricewaterhouseCoopers (2014), assurance resonates with the quality of financial statement, the paper uses financial statements as a proxy for assurance quality. Thus, these two variables - quality of performance reports and quality of financial statements - were measured and reported in the audited general reports of 2016/2017 and 2017/2018. Since these variables have been certified and reported by the Auditor General, these variables are thus deemed to be valid.

\section{Results and Discussion}

The main objective of this research is to examine the relationship between municipal governance quality and assurance quality in South African municipalities. Data reported in the consolidated municipal reports by the AGSA were collected from the AG's report archives. Table 1, table 2 and table 3 present the results of panel data regression analysis. Table 1 presents the result using the fixed-effect panel data regression; table 2 present the result for random-effect panel data regression. The purpose of using the two methods is to select the method that gives the best result, using the indicators generated by the Hannan-Quinn ratio, Akaike criterion ratio and the Schwarz criterion ratio (also presented in tables 1 and 2). Expert recommendation is that the alternative with lower ratios of Hannan-Quinn and Akaike criterion and the Schwarz criterion is a better model (Anderson, Burnham, and White 1998). Accordingly, a comparison of the indicators generated by these three model show the following: Schwarz criterion is 124.76 in the fixed effect model and 115.07 in the random effect model; Akaike criterion is 115.85 in the fixed effect model and 113.29 in the random effect model; Hannan-Quinn is 117.08 in the fixed effect model and 113.53 in the random effect model. Based on these comparisons, it is clear that the random effect model (table 2) presents the best regression model to analyse the link between governance quality and assurance quality. Therefore, although the two models show a significant relationship between governance quality and assurance quality, the conclusions drawn in this paper are based on the random effect model (table 2). 
TABLE 1 Result of the Relationship between Quality of Performance Report (QPerfRep) and Financial Statement Quality (FSQ): Model 1

\begin{tabular}{lcccc}
\hline Item & Coefficient & Std. Error & $t$-ratio & $p$-value \\
\hline Const. & 4.34745 & 2.12739 & 2.0436 & $0.07526^{*}$ \\
QPerfRep & 1.14471 & 0.182984 & 6.2558 & $0.00024^{* * *}$ \\
\hline Mean dependent var. & 15.22222 & SD dependent var & 11.02167 \\
Sum squared resid. & 216.5686 & SE of regression & 5.202988 \\
$R^{2}$ & 0.895130 & Adjusted $R^{2}$ & 0.777151 \\
$F(9,8)$ & 7.587196 & $P$-value $(F)$ & 0.004482 \\
Log-likelihood & -47.92872 & Akaike criterion & 115.8574 \\
Schwarz criterion & 124.7611 & Hannan-Quinn & 117.0851 \\
\hline
\end{tabular}

Notes Model 1: Fixed-effects, using 18 observations. Included 9 cross-sectional units. Dependent variable: FSQ.

At an alpha level of 0.05 , table 2 shows that quality of the performance report (a proxy for governance quality in this paper) is significantly related to financial statement quality (a proxy for assurance quality) at a $p$-value of 0.00001 , which lower than 0.05 . This indicates the relationship enjoys a high level of significance, and shows that municipal governance quality does have a high influence on the quality of assurance provided, which in turn resonates with the quality of audited and published financial statements (holding other factors constant). This finding concurs with research based on private sector entities' reports, in which it was found that corporate governance quality affects the quality of audited financial statement (Cohen, Krishnamoorthy, and Wright 2002). Table 3 presents the model's validity tests, namely the Breusch-Pagan test for heteroskedasticity, the Hausman test for endogeneity, and the normality test. The results from table 3 show the following $p$-values: $0.87,0.92$ and 0.91 for Breusch-Pagan, Hausman and normality tests respectively. Since these $p$-values are all above the alpha level of 0.05 , this indicates that there is no heteroskedasticity, no endogeneity and that variables are normally distributed. Therefore, table 3 adds validity to the research results.

\section{Conclusion}

This paper has evaluated the relationship between municipal governance quality (with performance quality as its proxy) and the municipal assurance quality (using financial statement quality as its proxy). According the AGSA, South Africa's municipalities' levels of performance regarding 
TABLE 2 Result of the Relationship between Quality of Performance Report (QPerfRep) and Financial Statement Quality (F SQ): Model 2

\begin{tabular}{lcccc}
\hline Item & Coefficient & Std. Error & $t$-ratio & $p$-value \\
\hline Const. & 4.42643 & 1.94159 & 2.2798 & $0.03667^{* *}$ \\
QPerfRep & 1.1364 & 0.148217 & 7.6671 & $<0.00001^{* * *}$ \\
\hline Mean dependent var. & 15.22222 & SD dependent var & 11.02167 \\
Sum squared resid. & 456.8726 & SE of regression & 5.184097 \\
Log-likelihood & -54.64719 & Akaike criterion & 113.2944 \\
Schwarz criterion & 115.0751 & Hannan-Quinn & 113.5399 \\
\hline
\end{tabular}

NOtes Model 2: Random-effects (GLS), using 18 observations. Included 9 crosssectional units. Dependent variable: FSQ.

TABLE 3 Validity Tests

\begin{tabular}{ll}
\hline Breusch-Pagan test & Null hypothesis: Variance of the unit-specific error $=0$ \\
& Asymptotic test statistic: $\chi^{2}(1)=0.0239722$ \\
& with $p$-value $=0.876956$ \\
\hline Hausman test & Null hypothesis: GLs estimates are consistent \\
& Asymptotic test statistic: $\chi^{2}(1)=0.00824316$ \\
& with $p$-value $=0.927658$ \\
\hline Test for norm. of residual & Null hypothesis: error is normally distributed \\
& Test statistic: $\chi^{2}(2)=0.172386$ \\
& with $p$-value $=0.917417$ \\
\hline
\end{tabular}

service delivery, compliance with regulations and financial management has deteriorated over the years. Hence, in 2015, the A G S A highlighted the urgent need to improve the quality of municipal governance as this was recognised as a catalyst for improving municipal performance (service delivery). This AGSA report prompted this paper, the purpose of which was to determine whether the level of governance quality in 2016/2017 and 2017/2018 had contributed to an improvement in the assurance quality. Two models of panel data regression analysis were presented and both models show $p$-values of less than the alpha level of 0.05. This then shows that the quality of governance has a significant effect on the assurance level as reflected on the quality of the financial statements for the years $2016 / 2017$ and $2017 / 2018$. This finding compares favourably with research findings from the private sector. Thus this indicates that municipalities will be able to improve their service delivery levels and the quality of their 
financial management if there are improvements in their governance. The implication for municipal governance is that in order to improve governance quality, service delivery and the management of public funds, those in charge of appointing municipal leadership should consider appointing only personnel with relevant knowledge and experience. Doing so will increase the social and economic welfare of citizens and general economic growth.

A practical recommendation in support of this desire for improved governance is the recommendation that municipalities be required to undergo quarterly quality-of-governance and assurance checks, without waiting for outcomes of the AGSA's annual audits. Such a quarterly governance and assurance quality audit will identify quality weaknesses in key positions of leadership and allow for immediate corrective plans and actions to be undertaken, while the problems are still current, and before such weaknesses accumulate into enormous service delivery problems, and financial costs that are ultimately to the detriment of the citizens. In addition to this practical recommendation, the authors of this paper recommend that further research is undertaken to examine the relationship between governance quality and assurance quality at the national government level, to see if the same results apply. If the problems are similar to those identified at the municipal level this might then prompt the search for solutions that are more generally applicable.

\section{References}

Aars, J., and A. L. Fimreite. 2005. 'Local Government and Governance in Norway.' Scandinavian Political Studies 28 (3): 239-56.

Anderson, D. R., K. P. Burnham, and G. C. White. 1998. 'Comparison of Akaike Information Criterion and Consistent Akaike Information Criterion for Model Selection and Statistical Inference from CaptureRecapture Studies'. Journal of Applied Statistics 25 (2): 263-82.

Auditor-General South Africa. 2016. Consolidated General Report on the Local Government Audit Outcomes - MFMA 2015-2016. Pretoria: AuditorGeneral South Africa.

Beasley, M. S., J. V. Carcello, D. R. Hermanson, and T. L. Neal. 2009. 'The Audit Committee Oversight Process.' Contemporary Accounting Research 26 (1): 65-122.

Bobonis, G. J., L. R. Cámara Fuertes, and R. Schwabe. 2016. 'Monitoring Corruptible Politicians.' American Economic Review 106 (8): 2371-405.

Cash, C. 2016. 'Good Governance and Strong Political Will: Are They Enough for Transformation?' Land Use Policy 58:545-56. 
Chohan, U., and K. Jacobs. 2016. 'A Parliamentary Budget Office in Fiji: Scope and Possibility.' Australasian Parliamentary Review 31 (2): 11729.

Chowdhury, M. S. 2017. 'Public Forums for Social Accountability: A Study of Ward Shava and Open Budget System of o6 (Six) Union Parishads of Bangladesh.' Asian Journal of Governance and Development 2 (1): 2146.

Cohen, J., G. Krishnamoorthy, and A. M. Wright. 2002. 'Corporate Governance and the Audit Process.' Contemporary Accounting Research 19 (4): 573-94.

Connolly, J. M. 2016. 'The Impact of Local Politics on the Principal-Agent Relationship between Council and mManager in Municipal Government.' Journal of Public Administration Research and Theory 27 (2): 25368.

Davies, M. 2009. 'Effective Working Relationships between Audit Committees and Internal Audit - The Cornerstone of Corporate Governance in Local Authorities, a Welsh Oerspective.' Journal of Management \& Governance 13 (1-2): 41-73.

Degeling, P., J. Anderson, and J. Guthrie. 1996. 'Accounting for public Accounts Committees.' Accounting, Auditing \& Accountability Journal 9 (2): 30-49.

De Graaf, G., and H. Paanakker. 2015. 'Good Governance: Performance Values and Procedural Values in Conflict.' The American Review of Public Administration 45 (6): 635-52.

De Roo, G. 2017. Environmental Planning in the Netherlands: Too Good to Be True; From Command-and-Control Planning to Shared Governance. London: Routledge.

DeZoort, F. T., D. R. Hermanson, and R. W. Houston. 2003. 'Audit Committee Support for Auditors: The Effects of Materiality Justification and Accounting Precision. Journal of Accounting and Public Policy 22 (2): 175-99.

Dweba, Z. M. 2017. 'Assessment of the Role of Leadership in the Successful Implementation of Performance Management: The Case of Municipalities in the Eastern Cape.' Journal of Public Administration 52 (2): 408-37.

Egner, B., A. Gendźwiłł, P. Swianiewicz, and W. Pleschberger. 2018. 'Mayors and Political Parties.' In Political Leaders and Changing Local Democracy: The European Mayor, edited by H. Heinelt, A. Magnier, M. Cabria, and H. Reynaert, 327-58. Cham: Palgrave Macmillan.

Fiolleau, K., K. Hoang, and B. Pomeroy. 2019. 'Auditors' Communications with Audit Committees: The Influence of the Audit Committee's Oversight Approach.' Auditing: A Journal of Practice \& Theory 38 (2): 125-50. 
Gendron, Y. 2009. 'Discussion of the Audit Committee Oversight Process: Advocating Openness in Accounting Research.' Contemporary Accounting Research 26 (1): 123-34.

George, B., S. Desmidt, and J. De Moyer. 2016. 'Strategic Decision Quality in Flemish Municipalities.' Public Money \& Management 36 (5): 317-24.

Gilchrist, D., and K. Coulson. 2015. 'Pragmatism, Black Letter Law and Australian Public Accounts Committees.' In Making Governments Accountable: The Role of Public Accounts Committees and National Audit Offices, edited by Z. Hoque, 141-47. Abingdon: Routledge.

Goddard, A. 2005. 'Accounting and NPM in UK Local Government Contributions towards Governance and Accountability'. Financial Accountability \& Management 21 (2): 191-218.

Grimmelikhuijsen, S. G., and M. K. Feeney. 2017. 'Developing and Testing an Integrative Framework for Open Government Adoption in Local Governments.' Public Administration Review 77 (4): 579-90.

Guragain, R., S. Pradhan, D. K. Maharjan, and S. N. Shrestha. 2017. 'Building Code Implementation in Nepal: An Experience on Institutionalizing Disaster Risk Reduction in Local Governance System.' In Science and Technology in Disaster Risk Reduction in Asia, edited by R. Shaw, K. Shiwaku, and T. Izumi, 207-20. Cambridge, m A: Academic Press.

He, X., J. A. Pittman, O. M. Rui, and D. Wu. 2017. 'Do Social Ties between External Auditors and Audit Committee Members Affect Audit Quality?' The Accounting Review 92 (5): 61-87.

Hirsch, B., C. Nitzl, and J. Schauß. 2015. 'The Influence of management Accounting Departments within German Municipal Administrations.' Financial Accountability \& Management 31 (2): 192-218.

Jackson, D. 2018. 'Explaining Municipal Governance in Kosovo: Local Agency, Credibility and Party Patronage.' Southeast European and Black Sea Studies 18 (2): 1-20.

Kamarudin, K. A., W. A. W. Ismail, Z. Yaacob, and S. S. A. Bakar. 2018. 'Auditor Specialization and Its Influence on the Association Between Governance and the Timeliness of Financial Reporting.' In State-of-the-Art Theories and Empirical Evidence: Selected Papers from the 6th International Conference on Governance, Fraud, Ethics, and Social Responsibility, edited by R. Said, N. Zahirah, M. Sidek, and Z. Azhar, 93-106. Singapore: Springer.

Khalo, T. 2013. 'Accountability and Oversight in Municipal Financial Management: The Role of Municipal Public Accounts Committees.' Journal of Public Administration 48 (4): 579-93.

Leck, H., and D. Roberts. 2015. 'What Lies Beneath: Understanding the Invisible Aspects of Municipal Climate Change Governance.' Current Opinion in Environmental Sustainability 13:61-67. 
Leitão, J., H. Alves, and D. Pereira. 2016. 'Open Innovative Governance, Municipalities Transparency and Citizens Quality of Life: Are They a Perfectly Matched Trilogy?' In Entrepreneurial and Innovative Practices in Public Institutions, edited by J. Leitão and H. M. Alves, 169-88. Cham: Springer.

Liao, Y. 2018. 'Toward a Pragmatic Model of Public Responsiveness: Implications for Enhancing Public Administrators Responsiveness to Citizen Demands.' International Journal of Public Administration 41 (2): 159-69.

Mahdavian, M., V. Mirabi, and F. Haghshenas. 2014. 'A Study of the Impact of Strategic Thinking on the Performance of Mashhad Municipal Managers.' Management Science Letters 4 (4): 679-90.

Maserumule, M. H. 2008. 'Framework for Strengthening the Capacity of Municipalities in South Africa: A Developmental Local Government Perspective.' Journal of Public Administration 43 (2): 436-51.

Matovu, G. 2018. 'Policy Options for Good Governance and Local Economic Development in Eastern and Southern Africa.' In Local Economic Development in the Changing World, edited by E. Nel and C. M. Rogerson, 341-53. London: Routledge.

Meloche, J. P., and P. Kilfoil. 2017. 'A Sizeable Effect? Municipal Council Size and the Cost of Local Government in Canada.' Canadian Public Administration 6o (2): 241-67.

Motubatse, K. N. 2016. 'The Impact of Audit Committees on Local Government Governance.' Paper presented at the 5th Annual Conference on ' 20 years of South Africa's Post-Apartheid Local Government Administration.' Mokopane, 26-8 October.

Natal'ya, V. B., V. V. Bondaletov, S. A. Makushkin, N. F. Bondaletova, and M. S. Kozyrev. 2016. 'Public Administration and Municipal Governance and Its Significance for a Modern Democratic Society.' International Journal of Economics and Financial Issues 6 (8): 220-24.

National Treasury. 2006. A Guide to Municipal Finance Management for Councillors. Pretoria: National Treasury.

Nealer, E. J. 2009. 'Municipal Governance and Environmental Crises: Threats and Thoughts.' TD: The Journal for Transdisciplinary Research in Southern Africa 5 (1): 73-85.

Nelson, K. L., and J. H. Svara. 2015. 'The Roles of Local Government Managers in Theory and Practice: A Centennial Perspective.' Public Administration Review 75 (1): 49-61.

Nurudin, S. M., R. Hashim, N. Zulkifli, S. Rahman, S. A. Hamik, and A. S. P. Mohamed. 2017. 'Good Governance Practices at Local Government: Experience from the Seremban Municipal Council.' Advanced Science Letters 23 (1): 457-61. 
Pelizzo, R., and A. Kinyondo. 2014. 'Public Accounts Committees in Eastern and Southern Africa: A comparative Analysis.' Politics \& Policy 42 (1): 77-102.

Porumbescu, G. A. 2015. 'Using Transparency to Enhance Responsiveness and Trust in Local Government: Can It Work?' State and Local Government Review 47 (3): 205-13.

PricewaterhouseCoopers. 2014. 'Combined Assurance and Corporate Governance.' PricewaterhouseCoopers. https://www.pwc.co.za/en/assets/ $\mathrm{pdf} /$ combined-assurance-brochure-jan-2015.pdf

Republic of South Africa. 1998. 'Municipal Structures Act 1998: Act No. 117 of 1998 as Amended.' Pretoria: Republic of South Africa.

Rotberg, R. I. 2014. 'Good Governance Means Performance and Results.' Governance 27 (3): 511-18.

Schmidt, S., and E. Zakayo. 2018. 'Land Formalization and Local Leadership in Moshi, Tanzania.' Habitat International 74:18-26.

Siegel, D. 2015. Leaders in the Shadows: The Leadership Qualities of municipal Chief Administrative Officers. Toronto: University of Toronto Press.

Steyvers, K., H. Reynaert, K. De Ceuninck, and T. Valcke. 2006. 'Mayors in Governance: Heading for Efficiency and Democracy? The Belgian Case.' Local Government Studies 32 (4): 429-45.

Ter Bogt, H. 2018. 'NP M's Ideals About the Accountability and Control of Outsourced Activities: Tough, But Realizable, or a Utopian Dream?' European Policy Analysis 4 (1): 118-45.

Van der Jagt, A. P., L. R. Szaraz, T. Delshammar, R. Cvejić, A. Santos, J. Goodness, and A. Buijs. 2017. 'Cultivating Nature-Based Solutions: The Governance of Communal Urban Gardens in the European Union.' Environmental Research 159:264-275.

Whiteoak, J. 1996. 'Corporate Governance - Why Local Government Should Manage Its Own Agenda.' Public Money \& Management 16 (2): 23-29.

Wong, K. 2017. Implementing Community Climate Change Action Plans in Canada: The Relationship between Implementation Structure and Outcomes. Master's thesis, University of Waterloo. 


\title{
Omnipresent Social Media: Is Travelling Imaginable without Smart Devices?
}

\author{
Zsuzsanna Marton \\ University of Pannonia, Hungary \\ marton.zsuzsanna@uni-pen.hu \\ Ildikó Ernszt \\ University of Pannonia, Hungary \\ ernszt.ildiko@uni-pen.hu
}

As earlier people went on holidays for the relaxation and the feeling of escape from the ordinary weekdays, nowadays most of them cannot imagine to spend a few days without internet connection or their smartphones during travels. The benefits of using smart phones and social media cannot be questioned, however, the drawbacks have to be also considered. To reveal the cons and pros of the phenomenon, first a brief theoretical overview of the topic is introduced, and then the analysis of the results of the empirical research involving 386 people in Hungary are put into the focus of this paper. The online survey conducted in Autumn 2019 gave the opportunity to study the mobile phone and social media usage habits of the Hungarians during their holidays. Simple descriptive statistics and the method of multidimensional scaling (MDS) with ALSCAL procedure were applied to illustrate the perceptions and attitudes of the respondents, and to interpret the hidden relationships among the variables. The results show that the smart tools and social media are organic parts of the holidays: $90 \%$ of the respondents use social media platform like Facebook daily, and $48 \%$ said that they use their mobile phones less during holidays compared to the everyday. However, only $13.5 \%$ of them would be willing to mitigate the usage of smart devices totally, while in case of social media usage this proportion is higher, $37.9 \%$.

Key Words: tourism, smart tools, social media, consumer behaviour, digital detox

JEL Classification: z33

(c))BY-SA https://doi.org/10.26493/1854-6935.18.301-321

\section{Introduction}

Digital transformation is not optional anymore; all sectors are highly exposed to it, which brought considerable changes in consumer behaviour and in the whole environment of the insdustries (Tomičić Fur- 
jan, Tomičić-Pupek, and Pihir 2020; Marušić et al. 2019; Bach et al. 2019; Gössling 2021). The importance of using modern technology, social media in tourism sector is recognised by most service providers (Paliokas et al. 2020). However, there are still some cultural institutions in the world, which are reluctant to use digital solutions which could make them to be more visible (Akca 2020).

In the digital era, the info-communication and technological (hereinafter ICT) innovations have also significantly changed the consumer behaviour of tourists. The opportunities provided by the smart tools, the applications and the different online platforms make the travel decisionmaking process easier, faster and more transparent. The tools are colorful: travel recommender systems, even data mining applications were developed (Renjit, Sreekumar, and Jathavedan 2020; Bach et al. 2019). People often choose their next destinations based on others' reviews, photos or suggestions, book their flights and the accommodations on their mobiles, and share their real-life holiday experiences via smart tools. A research made in Malaysia revealed, that the social media is the strongest influencing factor for millennials when making domestic travel decisions (Moorthy et al. 2020).

Social media had an important role even in case of group travels, since in certain situations it is vital in replanning the on-site activities, getting information about local news and connecting to travel mates and family at home (Fardous, Du, and Hansen 2020). Furthermore, social media can also contribute to getting knowledge about the destination, and to sociological adaptation ( $\mathrm{Li}$ et al. 2020).

Thanks to the Internet and social media, more and more destinations can open their gates for potential travellers. Travellers may reach destinations, they have never heard about before, and make them known for others by sharing their experiences immediately on site, which facilitates the phenomenon of overtourism. Therefore, it is important to make decisions consciously and think over their long-term effects in the sake for sustainable development and responsible behaviour (Moric 2013).

The tourists' behaviour and their needs have gone through a considerable change that also have made a shift in the supply side of the destinations. In the mid of the 2oth century, when mass tourism started to flourish, people wished to travel to destinations providing the combination of 'sun, sea and sand' (Aguiló, Alegre, and Sard 2005). The destinations and service providers struggled to build their activities on this combination that strongly depended on seasonality and the tourism infrastruc- 
ture. Therefore, many destinations left out of tourism due to the lack of 'basic' elements of the touristic operations. More and more destinations recognized the potential in tourism and started to consciously build out the basic and touristic infrastructure. Not only the 'sun and sand' destinations benefited from tourism, but also the destinations with natural or cultural attractions can enter the tourism market. Destination marketing organizations, national tourism organizations also use social media as a marketing tool, meanwhile it could also be utilized as a customer service tool (Usakli 2017; Curlin, Pejić Bach, and Miloloža 2019; Molina et al. 2020).

Social networks can also help in the branding of different destinations or service providers (Blace, Coric, and Juric 2015; Huerta-Alvarez, Cambra-Fierro, and Fuentes-Blasco 2020; Peco-Torres, Polo-Pena, and Frias-Jamilena 2020; Barreda et al. 2020; Moro and Rita 2018; Yu, Xie, and Wen 2020). Seo, Park, and Choi (2020) conducted a research among airline social media users about 'the effect of social media usage characteristics on electronic word-of-mouth (e-woM), trust, and brand equity'. It turned out, that the e-wом had determining impact on trust, brand awareness and brand image (Seo, Park, and Choi 2020).

However, the attractions themselves are not satisfying for the tourists anymore. They want experiences that they can share offline (with their travel companions) and online (with their fellows on social media (Falk and Hagstein 2020). Behind the travel motivation, there is often a push from friends on social media, who post their travel experiences on photos or videos (Aggarval and Gour 2020; Latif et al. 2020). Mainly the younger generations do not want to lag, and target the next tourist destinations under this pressure. Being continuously online and using our smart tools without stop pervade our holidays, as well. Using the navigation, searching for good-rated restaurants, reading QR codes for getting information on site are all the parts of holidays for better tourist experiences and satisfactions. Moreover, these experiences have to be or must be shared on social media that also needs the inevitable use of smart tools. Social media has become a fundamental attribute of holidays, which creates an interactive platform for communication being beneficial to all parties ( $\mathrm{Ai}, \mathrm{Lv}$, and Gursoy 2020). Reviews, feedback written by the users are not only useful for other tourists, but also the service providers can benefit from them (Leung et al. 2013). Social media can support the increase in effectiveness of knowledge management and business operations of the companies, services providers (Kašćelan et al. 2020). To be able to maintain 
the competitiveness and increase the market share on the market, service providers have to keep up with the latest social media trends and to identify the opportunities and react in time (Mabić, Gašpar, and Lucović 2017).

The advantages of the Internet and social media are undoubted, however, the focus has started to divert from the original purpose of holidays just, for example, stepping out from the weekdays, relaxing or discovering. This paper aims to study the role of social media and mobile use in tourism based on a literature overview, and to reveal the tourists' habits of use of smart tools, as well as social media on holidays. 386 Hungarian people were involved in the empirical research.

\section{Literature Review}

THE IMPACT OF MOBILE USAGE ON TOURISTS'BEHAVIOUR

By the spread of smart phones and tools, calling and texting have become secondary functions, and the opportunities provided by these smart tools (e.g. social networking, information search, weather forecast) got into focus (Yang 2013; Tan et al. 2017). By using mobile devices during travel gives the opportunity the tourists to be more connected, confident, informed and safe (Wang, Xiang, and Fesenmaier 2016). However, there are several benefits of mobile usage, that can make our lives and holidays more convenient, the number of disadvantages is not negligible. According to Travelers Today (2019), people use mobile devices for navigation, translation, information search, booking, as well as to keep in touch with friends, to share on social media, either to download travel applications or use travel guides. Nevertheless, the (excessive) use of these tools can cause distraction, poor concentration on attractions, the lack of experience, and less mindfulness.

Travel experts, portals predict that the importance of modern technology will even increase in the post-covid world. It will be essential for travellers to get the latest travel information (Tourwriter 2020). A survey carried out by Censuswide revealed, that the trust of more than $80 \%$ of travellers would be heightened because of modern technology in the next year. Regarding this trust, most of them $(42 \%)$ have referred to a special mobile application giving them alerts, notifications during their trip about possible safety and security threats. Contactless payments and mobile boarding would also be suitable to increase their confidence to travel' Amadeus 2020). The role and the significance of mobile use are de- 
cisive only during travel, but it has an impact on the whole travel decisionmaking process, too.

Making travel decision can be regarded as a quite complicated process that requires various information sources in different phases. The information search process is very crucial from the destination choice's point of view (Bieger and Laesser 2004; Jacobsen and Munar 2012). The Internet and IC T tools have brought a fundamental shift in consumer behaviour of tourists already from the first step of the decision-making process. The smartphones in people's pockets have become a perfect travel companion throughout the whole journey (Thinkwithgoogle 2016).

Mobile devices are important tools of getting tourism information (Lin, Juan, and Lin 2020). According to the findings of 'think with Google' research among us people, the $60 \%$ of destination information searches were carried out by mobile devices, while the $31 \%$ of the leisure travellers and more than half of the business travellers booked on smartphones. Regarding the top travel activities, $44 \%$ of the respondents searched for discounted offers, 35 and $32 \%$ looked for destination-related information before visiting the destination and during their staying. The key findings of this research show that people desire simplicity and convenience while they use their smartphones in connection to travel.

While Thinkwithgoogle (2016) analysed usage habits from a practical perspective, Pavelka (2016) studied smartphone use during travel from the psychological side, as well. The feeling by using smartphones during travel was in the focus of the research. Based on the results of the survey conducted in the UK, $98 \%$ of the UK respondents, the travel is more comfortable by using smartphones; $78 \%$ of them feel safer with using a smartphone.

Other research in the UK (Dickinson et al. 2014) analysed the importance of mobile applications during travel that has to be more personalized, and have to keep up with the latest consumer trends and needs. Mobile apps with numerous functions drive tourists to download them since with their usage the trip can be easier. Even though these applications are getting more popular, $82 \%$ of us people have never paid for downloading apps, rather use free options (Thinkwithgoogle 2016). According to this $\mathrm{UK}$ research, the top motivating factor for downloading travel apps is to make a specific activity or task easier (36\%). $32 \%$ of the respondents was motivated to download by other recommendations and to access discount and offers during travel. Using mobile applications undoubtedly make the trip easier, and might make it more meaningful and 
informative, however, the questions arise, how tourists can live the experiences while they are stuck to the screen.

SOCIAL MEDIA AND TRAVEL DECISION-MAKING

Millions of people use social media sites daily, which became the primary communication platforms among the most of age groups (Balan and Rege 2017). Social media has affected consumers' lives in many ways: how they perceive the world and their surrounding environments, how they see others, how they manage the daily tasks, just as purchase processes (Månsson 2011). The research of Yang and Wong (2020) revealed a special aspect of social media during the covid pandemic: the social media presence and activity functions as a means of distraction the negative stress regarding COVID-19 quarantine.

The role and the impact of social media in tourism is unquestionable. On the one hand, it influences tourists' behaviour and business performance, on the other hand, it has an effect on the way how the tourists perceive the experiences, what posts they do, what content they share (Law, Buhalis, and Cobanoglu 2014). Businesses, service providers already recognized that how they can influence their customers and how they engage them to choose their services (Nayak, Nayak, and Jena 2020).

Deciding on the potential target destination is never easy since it is based on a multistep model influenced by many factors (Woodside and Lysonski 1989). Technological innovations (e.g. the evolution of Web 1.0 to two-way communication sites (Web 2.0 and 3.0) brought new concepts on the tourism market as well. Under the concept of Travel 2.0 consumers are empowered by information, they can easily have access to everything (e.g. experiences, services, and everybody (other travellers and non-travellers) (Miguéns, Baggio, and Costa 2008; Roblek et al. 2013). Creating, consuming and diffusing travel information through the Internet in the frame of consumer generated content (CGM) all contribute to a new approach to the travel decision-making (Al-Tit, Omri, and Hadj 2020). The feedback given by the tourists on social media can boost the service quality in the future, which increases revisit intension, as well (Markus et al. 2019).

More researches were conducted about the topic, in which travel phases tourists use social media most (Balouchi and Khanmohammadi 2015; Hussain, Li, and Wang 2018). The decision-making process can be divided into three main phases (before, during and after) in which social media has certain roles according to Dwityas and Briandana (2017). 
In the pre-trip phase, collaboration and interaction are mostly determining. The first trait of social media in this process can be traced back to the birth of motivation. In many cases, people are motivated by a photo uploaded on Facebook or Instagram, and then start to gather specific information about the destination itself, and make the final choice. Travel communities, blogs, booking or comparative websites all can help the decision-making. In this phase, the trust is social media is very important, because the reliability and the relevancy of information are questionable (Tang and Liu 2015). Consumers interact with each other, share their past experiences, make ratings.

In the 'during trip' phase, content sharing gets more importance. Li's academic studies have focused on the analysis of the motivations lagging photo-taking and sharing behaviours during travel (Munar and Jacobsen 2014; Li 2020; Sotiriadis 2017; Pan, Lee, and Tsai 2014). Based on their findings, the recognition and status, the enjoyment, the disclosure and the information-giving, external expectations drive people to post and share photos and videos about their trips.

Furthermore, another study pointed out the significance of sharing and posting in the post-trip evaluation. According to Kim and Fesenmaier (2017), those travellers who share their experiences on social media give more positive post-trip evaluations than who do not share. Taylor investigated the effects of certain psychological features of travellers regarding sharing photographs in social media. The research strengthened, that narcissism, envy contribute to the sharing travel photos in social media as a tool for self-promotion (Taylor 2020).

Tourism experience, which is regarded as a multi-phased, activitybased process and phenomenon (Wang, Park, and Fesenmaier 2012; Gretzel, Fesenmaiers, and O'Leary 2016), does exist in all stages of trip (pre, during and post). It is highly affected by social media through the stages that evokes emotions and physiological processes (Holbrook and Hirschman 1981; Kim and Fesenmaier 2017).

\section{DIGITAL DETOX IS THE NEW TREND}

As it was mentioned, digital tools are organic parts of our lives that eventually force us to be continuously online and available for everyone in every minute. The use of modern tools is both a blessing and a curse in our lives, because on the one hand, they help to make our daily lives easier, on the other hand, they have taken control of us, they demand participation in almost every moment of our lives. 
Involving in the digital world starts at a younger age: research conducted by Huawei Technologies Hungary among Generation Y parents shows that about $90 \%$ of preschoolers between the ages of 4-6 use smart devices. In spite of this fact, the parents themselves believe that these kinds of smart tools should be put in the hands of children much later (Világgazdaság 2020).

Continuous digital existence, digital 'readiness' is also typical during travel. In addition, many find it difficult to bear the 'continuous' presence of modern technology, the never-ending 'online' state, which is quite exhausting, as in many cases it is already at the expense of rest and complete relaxation.

However, the continuous 'readiness' has been a trend, there was an urgent need to compensate its adverse effects, so a new trend against it appeared, which is called as digital detox (Pawlowska-Legwand and Matoga 2020; Egger, Lei, and Wassler 2020; Fan, Buhalis, and Lin 2019).

More and more people have recognized the need for giving up to be online and to escape from the digital world for a while. Even if we do not eliminate the usage of smart tools and social media platforms from our weekdays, the holiday is an excellent time to start excluding. Wilcockson, Osborne, and Ellis (2019) studied the so-called heavy mobile-users in laboratory after 24 hours from the smart tool withdrawal. After the withdrawal, the feelings and the general mood of the participants immediately decreased, however, by the end of the day, they started to be more relaxed and less stressful. Another research (Cai, McKenna, and Waizenegger 2019) examined the emotional states of the survey participants in three phases during their travel after the withdrawal of digital tools and social media platforms. The research brought similar results, the participants became more relaxed as the time went by, they enjoyed the holidays, and spent more meaningful time with their travel companions.

\section{Methodology}

In this chapter, the focus is on the introduction to the research instruments, the data and the sample characteristics, the applied statistical methods, as well as the validity of the research.

\section{RESEARCH INSTRUMENTS}

Our research aimed to reveal and analyse the smart device usage habits of people during their travel. A quantitate research was conducted in 2019 
TABLE 1 Structure of the Online Questionnaire

\begin{tabular}{ll}
\hline Question block & Description \\
\hline 1 General travel habits & $\begin{array}{l}\text { Frequency of travel } \\
\text { Motivation }\end{array}$ \\
\hline 2 Mobile phone usage habits during travel & Used smart devices \\
& Used smart phone functions \\
& Willingness to mitigation of smart phone \\
\hline 3 Social media usage habits during travel & Used social media platforms \\
& Frequency of posts \\
& Willingness to mitigation of smart phone \\
\hline 4 Socio-demographic data collections & Age, gender, education, occupation \\
\hline
\end{tabular}

Autumn in the frame of an online survey involving 386 respondents in Hungary. Based on the theoretical overview, question blocks with specific items were defined for compiling the questionnaire (table 1). The following research questions were drafted:

RQ1 How much does smartphone pervade the holidays of the respondents and which functions are determining concerning the usage?

RQ2 How much do social media and mobile usage affect the holidays? In what degree are the tourist able to mitigate their usage? How does age affect it?

\section{DATA}

Regarding the demographics (table 2) of the survey sample as shown in table $1,71.2 \%$ of the respondents were female, $28.8 \%$ was male. Most of them (69.9\%) belong to the youngest age group (18-25), 8.3\% represents the age group between $26-35$ years. The respondents aged between $36-$ 45 years are up to $8.3 \%$ in the sample, people above 45 represent ca. $10 \%$. Based on the highest education level of the respondents, those who have secondary school education showed the highest proportion, which is resulted in the large proportion of the youngest in the sample. Concerning the travel habits, the $61.7 \%$ of the respondents travel once or two times a year, $22.5 \%$ travel three or four times.

\section{STATISTICAL METHODS}

To get a reply to the research questions above and to reveal the attitudes and perceptions of the respondents, descriptive statistical analyses (e.g. frequencies, crosstabs - Chi-square test) and the method of multidimensional scaling (MDS) with ALSCAL procedure were applied. The MDS 
TABLE 2 Sample Profile

\begin{tabular}{|c|c|c|c|}
\hline Category & Item & $n$ & $\%$ \\
\hline \multirow[t]{6}{*}{ Age group } & $18-25$ years & 270 & 69.9 \\
\hline & $26-35$ years & 32 & 8.3 \\
\hline & $36-45$ years & 45 & 11.7 \\
\hline & $46-55$ years & 21 & 5.4 \\
\hline & $55-65$ years & 13 & $3 \cdot 4$ \\
\hline & $>65$ years & 5 & 1.3 \\
\hline \multirow[t]{2}{*}{ Gender } & Female & 275 & 71.2 \\
\hline & Male & 111 & 28.8 \\
\hline \multirow[t]{4}{*}{ Education } & Primary school & 11 & 2.8 \\
\hline & Secondary school & 302 & 78.2 \\
\hline & College/university & 70 & 18.1 \\
\hline & Postgraduate/PhD & 3 & 0.8 \\
\hline \multirow[t]{6}{*}{ Occupation } & Student & 240 & 62.2 \\
\hline & Entrepreneur & 9 & 2.3 \\
\hline & Public sector employee & 42 & 10.9 \\
\hline & Private sector employee & 88 & 22.8 \\
\hline & Retired & 1 & 0.3 \\
\hline & Other & 5 & 1.3 \\
\hline \multirow[t]{4}{*}{ Frequency of travel } & Not every year & 8 & 2.1 \\
\hline & 1-2 times a year & 238 & 61.7 \\
\hline & $3-4$ times a year & 87 & 22.5 \\
\hline & $>4$ times a year & 53 & 13.7 \\
\hline
\end{tabular}

model by creating a perception map illustrates the perceptions and preferences of the respondents in two-dimensional space (Malhotra 2002). Stress-value is the goodness-of-fit statistic that MDs tries to minimize; its value varies between 0 and 0.2 . The less the value of stress is, the better the fit is (Wilkinson 2013, 188). The statements in the questionnaire had to be evaluated by the respondents on 5-point Likert scales. For the analysis of relationships one-way ANOvA is used on 5\% significant level.

\section{VALIDIT Y}

The research questionnaire was compiled based on the relevant literature and earlier market researches introduced in the previous chapters, fur- 
TA B LE 3 The Popularity of Daily Usage of Different Smart Tools among the Respondents

\begin{tabular}{lrr}
\hline Item & No & Yes \\
\hline Smart phone & 2.1 & 97.9 \\
Tablet & 84.2 & 15.8 \\
Smart watch & 92.0 & 8.0 \\
Activity tracker & 94.3 & 5.7 \\
Other & 97.9 & 2.1 \\
None & 98.7 & 1.3 \\
\hline
\end{tabular}

NOTES In percent.

thermore, the applied methods followed them by using 5-point Likertscale, which is generally accepted and validated measurement scale.

\section{Results}

ANALYSIS OF TOURISTS' HABITS BASED ON SMART DEVICES'

USAGE: THE ROLE OF SMART FUNCTIONS

Regarding the usage of smart devices, smartphone usage is the most determining, $98 \%$ of the respondents use it daily. Using other smart tools like tablet or activity tracker is not so popular, only $5-15 \%$ of them use these tools daily (table 3).

Smart devices provide several opportunities that make holidays more comfortable and easier for tourists (table 4). $82.64 \%$ of the Hungarian respondents uses smart devices for contacting others. Navigation function can be regarded as important as chatting, since approximately $79 \%$ takes advantage of it. The results show that having smartphones or other smart tools makes people more confident, even though they do not bring it in parallel to the sense of safety and security. Surprisingly, the majority of the respondents $(75 \%)$ do not use smart devices for gathering information during travel.

As the result of the MDS configuration (figure 1), we can see that the respondents link certain items together in their perception. The stressvalue is 0.01220 meaning that the map is more than suitable for reliable interpretation, the results are significant.

According to the perceptions (distances between the points along the coordinate axis) survey participants differentiate four areas regarding the smart phone functions in two dimensions. Dimension 1 can be interpreted as the degree of importance of the smart phone functions. To 
TABLE 4 Smart Device Functions Used during Travel

\begin{tabular}{lrrrrrr}
\hline Function & 1 & 2 & 3 & 4 & 5 & Mean \\
\hline Information & 3.9 & 0.5 & 13.0 & 35.8 & 46.9 & 4.2 \\
Photos. videos & 3.1 & 4.1 & 13.5 & 26.9 & 52.3 & 4.2 \\
Navigation & 3.9 & 3.9 & 14.2 & 30.1 & 47.9 & 4.1 \\
Sense of security & 6.0 & 5.7 & 5.7 & 5.7 & 5.7 & 3.9 \\
Chat & 10.1 & 15.5 & 23.6 & 24.6 & 26.2 & 3.4 \\
Confidence & 15.8 & 18.4 & 27.5 & 23.1 & 15.3 & 3.0 \\
Post & 35.0 & 28.8 & 21.5 & 9.6 & 5.2 & 2.2 \\
Play & 55.4 & 20.2 & 13.5 & 5.7 & 5.2 & 1.9 \\
Payment & 57.8 & 17.6 & 11.1 & 9.1 & 4.4 & 1.8 \\
\hline
\end{tabular}

NOTES 1 - not at all agree, 5 - totally agree.

FIGURE 1

Perceptual Map of Smart Device Functions

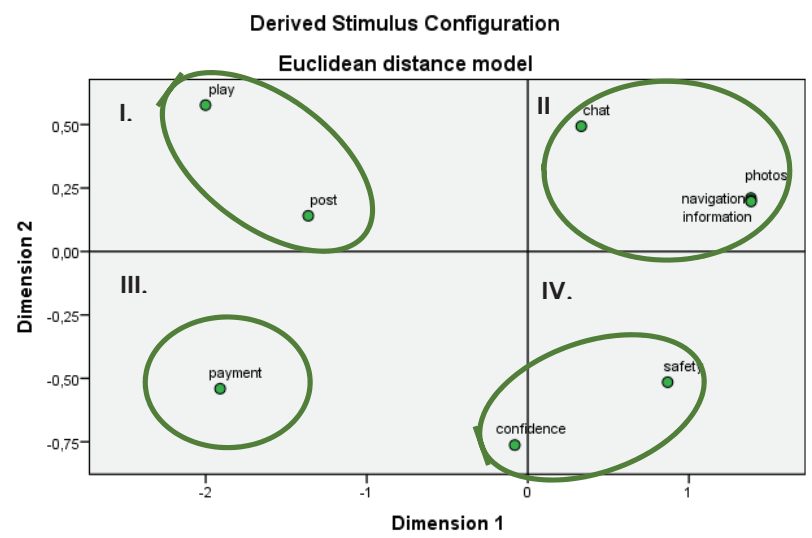

the right of the origo, those functions are located which are more important for the participant, at the opposite side of the dimension, the less preferred items can be found. The interpretation of Dimension 2 is more theoretical. The two opposite end-points of the axis can regarded as 'safety' (below) and 'pastime or entertainment' (above). We can see that the Hungarians perceive photo-taking, information-getting and navigation exactly in the same way. Not only they are just as important for the tourists, but also the respondents associate them with very similar content and needs. Eventually, these three functions (information, navigation and photo/video-taking) are the core and essential activities during travel. However, the chat function is located in this quarter of the coordinate system (perceptual map), it is further from the previous three functions. 
TABLE 5 Cluster-Based Approach of Functions Based on MSD Results

\begin{tabular}{lll}
\hline Main cluster & Sub-cluster & Items \\
\hline 1 Fully emotional & Entertainment & $\begin{array}{l}\text { Playing } \\
\text { Posting }\end{array}$ \\
\hline 2 Emotional \& functional & Communication & Chat \\
& \& information & $\begin{array}{l}\text { Photo-taking } \\
\text { Navigation }\end{array}$ \\
& & Information-search \\
\hline 3 Fully functional & Payment & Payment \\
\hline 4 Emotional \& functional & Safety & Feel of safety \\
& & Feel of confidence \\
\hline
\end{tabular}

According to the interpretation of the dimensions, chat has more entertainment function. Playing on smartphones and posting on social media are perceived not only less important, but also playing is particularly for entertainment. In the below quarters, the safety element of the functions is dominant. Using smart phones provides safety and makes people more confident, just as the payment function of them does. Nevertheless, the last one is less important for the survey participants. According to the results of the perceptual map, functions can be categorized based on the degree of emotional benefit (table 5).

\section{SOCIAL MEDIA AND SMART PHONE USAGE HABITS DURING HOLIDAY - THE DEGREE OF WILLINGNESS OF USAGE MITIGATION}

As it was described in the literature overview, social media is the organic part of our lives. The survey results also underpin this statement, hence almost $90 \%$ of the respondents use Facebook daily, $64 \%$ of them use Instagram. Concerning the social media presence during the holiday, $48 \%$ of the Hungarians never post from holidays, $19 \%$ does every day. The perceptual map also illustrated, that posting on social media is not really important $(m=2.2)$.

According to the replies, the Hungarians try to mitigate the usage of smart tools during the holiday, since $78 \%$ said that they used less them compared to everyday habits. The analysed age groups did not show any significant differences based on one-way ANOVA analysis $(p=0.054)$ on 5 percent significance level, each group struggles to use less. Even the elders (aged above 65) represent the highest mean value $(m=2.50)$ (table 6).

However, only half of the respondents $(50.8 \%)$ would be willing to 
table 6 anova Table for the Mitigation of Social Media and Mobile Usage by Age Groups

\begin{tabular}{llrrrrr}
\hline Category & & $(1)$ & $(2)$ & $(3)$ & $(4)$ & $(5)$ \\
\hline Mitigation of smart devices & Between Groups & 14.805 & 5 & 2.961 & 2.195 & 0.054 \\
& Within Groups & 512.534 & 380 & 1.349 & & \\
& Total & 527.339 & 385 & & & \\
\hline Mitigation of social media & Between Groups & 26.959 & 5 & 5.392 & 4.090 & 0.001 \\
& Within Groups & 499.602 & 379 & 1.318 & & \\
& Total & 526.561 & 384 & & & \\
\hline
\end{tabular}

Notes Column headings are as follows: (1) sum of squares, (2) degrees of freedom, (3) mean square, (4) $F$, (5) significance.

TABLE 7 The Willingness to Mitigate Smart Devices and Social Media Use During Travel

\begin{tabular}{lrrrrrr}
\hline Item & 1 & 2 & 3 & 4 & 5 \\
\hline Smart Devices & 8.3 & 19.9 & 21.0 & 37.3 & 13.5 \\
Social Media & 3.9 & 12.5 & 16.1 & 29.6 & 37.9 \\
\hline
\end{tabular}

NOTES 1 - not at all, 5 - totally. In percent.

eliminate its mobile usage during holidays. This proportion is higher $(67.5 \%)$ in case of the mitigation of usage of social media platforms (table 7).

The younger people testify more active social media presence than the older respondents. The respondents aged 18-25 post more frequently, hence sharing experiences more times a day characterizes them mostly. Respondents above 55 years do not post at all during their holiday.

In case of social media mitigation, the ANOva analysis showed significance difference between age groups $(p=0.001<0.05)$ (table 6). The biggest gap based on the means plot analysis, there is between the respondents aged $18-15$ and people above 65 years. Besides, the age group between 46-55 also stands out in the sample, after the youngest people, they are those who are willing to mitigate the least the social media usage during their trip.

\section{Discussion, Implication and Conclusion}

Technological innovations, the appearance of smart devices fundamentally changed the tourism industry, including the consumer behaviour of tourists. In our accelerated world, potential tourists are empowered 
by more information than ever, they can reach any destinations they want, and they can do all this via a smartphone or a smartwatch. They go nowhere without their smart 'buddies,' not even on holiday. Unfortunately, the holiday seems to lose its traditional value meaning relaxing or discovering with friends or families, instead, people travel to a destination just to show an image on social media, and keep up with others.

The present study confirms the current trend and the literature review, earlier market researches that smart devices undoubtedly became the organic parts of our lives. The survey results also justify the fact that people's holiday and related habits have considerably changed due to technological innovations and devices. During the holiday, smart devices can provide many advantages that make the holiday more comfortable. Navigation and chat functions are the most popular among the respondents, but they also prefer to take photos or play with smart devices.

Some forms of social media platforms are known by all respondents, but Facebook is the most beloved among them. Posting and sharing experiences on social media are rather preferred by the youngest tourists (18-25 years), the quarter of them post from holiday daily.

The results suggest that people want to get rid of using smartphones/ devices so much during holiday, however, only a minority of them would be willing to eliminate its usage during travel.

Not only researches confirmed that the consumer behaviour of the people changed due to the digitalization, but also consumers often admit that the disadvantaged and the excessive use of smart devices, especially during the holiday. The constant online mode can alter the quality of life and human relationships, too. In 2021 'working from anywhere in the world' has created the special notion of 'digital nomad visa, which creates the possibility of working from abroad for a longer period of time for remote workers' (Etias News n.d.).

In the tourism industry, the answer given to the above-mentioned trend is a new trend in the form of 'digital detox.' The service providers recognized that organizing a camp or tour focusing on digital detox could be a new market niche that should be more utilized in the future. As the survey results showed people involved in the survey also drew up the hidden need by saying that they try to mitigate the usage of smart devices and social media platforms.

However, the results gave a general overview of the current situation of the consumer behaviour related to smart tool and social media usage, and they are consistent with earlier study result, we have to mention the 
limitation of the research. The sample including 386 participants, but not representative for the Hungarian population (tourists). Furthermore, the survey questions focused only the 'during-trip' phase, while the before and after phases would be interesting from the perspective of social media usage.

Since the research was conducted in 2019 before the outbreak of CoviD-19, many changes might have occurred in tourists' behaviour. According to travel experts, portals, the importance of modern technology will even increase in the post-covid world further. The phased of decision-making process and the travels themselves have already been considerably affected by smart tools, however, its significance will be more dominant, and will become more inseparable part of our travels. Therefore, regarding future researches, there would be worth to analyse the impacts of COVID-19 on technological developments related to tourism industry and the attitude of the tourists towards them.

\section{Acknowledgments}

The preliminary version of the paper was presented at Entrenova 2020 Conference, Split, 10-12 September.

\section{References}

Aggarval, S., and A. Gour. 2020. 'Peeking Inside the Minds of Tourists Using a Novel Web Analytics Approach.' Journal of Hospitality and Tourism Management 45:580-91.

Ai, J., X. Lv, and D. Gursoy. 2020.'Impact of Social Media Posts on Travelers' Attitudes and Behaviors towards a Destination After a Natural Disaster: Moderating Role of the Source of the Post.' Journal of Sustainable Tourism. https://doi.org/10.1080/09669582.2020.1831002.

Akca, S. 2020. 'Museums in the Age of Technology and Information: Overview.' Turkish Librarianship 34 (2): 263-74.

Aguiló, E., J. Alegre, and M. Sard. 2005. 'The Persistence of the Sun and Sea Tourism Model.' Tourism Management 26 (2): 219-31.

Al-Tit, A. A., A. Omri, and T. B. Hadj. 2020. 'The Driving Factors of the Social Commerce Intention of Saudi Arabia’s Online Communities.' International Journal of Engineering Business Management 12:1-8.

Amadeus. 2020. 'Travel Trends in 2021 - Prepare for a Year of New Opportunities.' PhocusWire, 22 December. https://www.phocuswire.com/ Travel-trends-2021-year-of-changes.

Barreda, A. A., K. Nusair, Y. C. Wang, F. Okumus, and A. Bilgihan, A. 2020. 'The Impact of Social Media Activities on Brand Image and Emotional 
Attachment: A Case in the Travel Context.' Journal of Hospitality and Tourism Technology 11 (1): 109-35.

Bach, M. P., S. Seljan, B. Jaković, A. Buljan, and J. Zoroja. 2019. 'Hospital Websites: From the Information Repository to Interactive Channel.' Procedia Computer Science 164:64-71.

Balan, S., and J. Rege. 2017. 'Mining for Social Media: Usage Patterns of Small Businesses.' Business Systems Research: International Journal of the Society for Advancing Innovation and Research in Economy 8 (1): 43-50.

Balouchi, M., and E. Khanmohammadi. 2015. 'Using Logarithmic Fuzzy Preference Programming To Prioritization Social Media Utilization Based On Tourists' Perspective.' Foundations of Management 7 (1): 718.

Bieger, T., and C. Laesser. 2004. 'Information Sources for Travel Decisions.' Journal of Travel Research 42 (4): 357-71.

Blace, D., G. Coric, and B. Juric. 2015. 'Branding the City of Sibenik as a Sustainable Tourist Destination Using Social Networks.' Ekonomski vjesnik 28:9-124.

Cai, W., B. McKenna, and L. Waizenegger. 2019. 'Turning It Off: Emotions in Digital-Free Travel.' Journal of Travel Research 59 (5): 909-927.

Ćurlin, T., M. Pejić Bach, and I. Miloloža. 2019. 'Use of Twitter by National Tourism Organizations of European Countries.' Interdisciplinary Description of Complex Systems 17 (1B): 226-41.

Dickinson, J. E., K. Ghali, T. Cherrett, C. Speed, N. Davies, and S. Norgate. 2014. 'Tourism and the Smartphone App: Capabilities, Emerging Practice and Scope in the Travel Domain.' Current Issues in Tourism 17 (1): 84-101.

Dwityas, N. A., and R. Briandana. 2017. 'Social Media in Travel Decision Making Process.' International Journal of Humanities and Social Science 7 (7): 193-201.

Egger, I., S. I. Lei, and P. Wassler. 2020. 'Digital Free Tourism - An Exploratory Study of Tourist Motivations.' Tourism Management 79: 104098. https://doi.org/10.1016/j.tourman.2020.104098.

Etias News. N.d. 'Digital Nomad Visas in E U Countries' https://www .etiasvisa.com/etias-news/digital-nomad-visas-eu-countries.

Falk, M. T., and E. Hagstein. 2020. 'Visitor Flows to World Heritage Sites in the Era of Instagram.' Journal of Sustainable Tourism. https://doi.org/10 $.1080 / 09669582.2020 .1858305$.

Fan, D. X. F., Buhalis, D. and Lin, B. N. (2019). 'A Tourist Typology of Online and Face-to-Face Social Contact: Destination Immersion and Tourism Encapsulation/Decapsulation.' Annals of Tourism Research 78:102757. https://doi.org/10.1016/j.annals.2019.102757. 
Fardous, J., J. T. Du, and P. Hansen. 2020. 'Collaborative Information Seeking during Leisure Travelling: Triggers and Social Media Usage.' Information Research 24 (3): 830.

Gössling, S. 2021. 'Technology, IC T and Tourism: From Big Data to the big Picture.' Journal of Sustainable Tourism 29 (5): 733-50.

Gretzel, U., D. R. Fesenmaiers, and J. T. O'Leary. 2006. 'The Transformation of Consumer Behaviour.' In Tourism Business Frontiers, edited by D. Buhalis and C. Costa, 9-18. Oxford: Elsevier.

Holbrook, M. B., and E. C. Hirschman. 1981. 'The Experiential Aspects of Consumption: Consumer Fantasies, Feelings, and Fun.' Journal of Consumer Research 9 (September): 132-40.

Huerta-Alvarez, R., J. L. Cambra-Fierro, and M. Fuentes-Blasco. 2020. 'The Interplay between Social Media Communication, Brand Equity and Brand Engagement in Tourist Destinations: An Analysis in an Emerging Economy' Journal of Destination Marketing \& Management 16:100413. https://doi.org/10.1016/j.jdmm.2020.100413.

Hussain, T., B. Li, D. Wang. 2018. 'What Factors Influence the Sustainable Tour Process in Social Media Usage? Examining a Rural Mountain Region in Pakistan.' Sustainability 10 (7): 2220. https://doi.org/10.339o/ su10072220.

Jacobsen, J. K. S., and A. M. Munar. 2012. 'Tourist Information Search and Destination Choice in a Digital Age.' Tourism Management Perspectives 1:39-47.

Kašćelan, L., M. Pejić Bach, B. Rondović, and T. Đuričković. 2020. 'The Interaction between Social Media, Knowledge Management and Service Quality: A Decision Tree Analysis.' PLOS ONE 15 (8): e0236735.

Kim, J., and D. R. Fesenmaier. 2017. 'Sharing Tourism Experiences: The Posttrip Experience.' Journal of Travel Research 56 (1): 28-40.

Latif, K., M. Y. Malik, A. H. Pitafi, S. Kanwal, and Z. Latif. 2020. 'If You Travel, I Travel: Testing a Model of When and How Travel-Related Content Exposure on Facebook Triggers the Intention to Visit a Tourist Destination.' Sage Open 10 (2). https://doi.org/10.1177/ 2158244020925511.

Law, R., D. Buhalis, and C. Cobanoglu. 2014. 'Progress on Information and Communication Technologies in Hospitality and Tourism.' International Journal of Contemporary Hospitality Management 26 (5): 72550.

Leung, D., R. Law, H. van Hoof, and D. Buhalis. 2013. 'Social Media in Tourism and Hospitality.' Journal of Travel \& Tourism Marketing 30 (12): 3-22.

Li, F. 2020. 'Understanding Chinese Tourists' Motivations of Sharing Travel Photos in WeChat.' Tourism Management Perspectives 33:1-13. 
Li, C., S. Guo, C. L. Wang, and J. Zhang. 2020. 'Veni, Vidi, Vici: The Impact of Social Media on Virtual Acculturation in Tourism Context.' Technological Forecasting and Social Change 145:513-22.

Lin, S. Y., P. J. Juan, and S. W. Lin. 2020. 'A тА M Framework to Evaluate the Effect of Smartphone Application on Tourism Information Search Behavior of Foreign Independent Travelers.' Sustainability 12 (22): 9366. https://doi.org/10.339o/su12229366.

Mabić, M., D. Gašpar, and D. Lucović. 2017. 'Presence of Banks on Social Networks in Bosnia and Herzegovina.' Business Systems Research: International journal of the Society for Advancing Innovation and Research in Economy 8 (2): 59-70.

Malhotra, N. K. 2002. Marketingkutatás. Budapest: Közgazdasági és Jogi Kiadványok.

Månsson, M. 2011. 'Mediatized Tourism.' Annals of Tourism Research 38 (4): 1634-52.

Markus, Z., D. Perovic, S. Pekovic, and S. Popovic. 2019. 'Assessing Tourist Revisit Intention through the Sports and Recreational Services Offered.' Business Systems Research: International journal of the Society for Advancing Innovation and Research in Economy 10 (2): 141-50.

Marušić, Z., A. Aleksić, M. Pejić Bach, M. A. Omazić, and J. Zoroja. 2019. 'Determinants of Innovation in Hotel and Travel Agency Service Industry: Impact of Information and Communication Technologies and Enterprise Readiness.' Interdisciplinary Description of Complex Systems 17 (1B): 209-25.

Miguéns, J., R. Baggio, and C. Costa. 2008. 'Social Media and Tourism Destinations: Tripadvisor Case Study'. Advances in Tourism Research 26 (28): 1-6.

Molina, A., M. Gomez, A. Lyon, E. Aranda, and W. Loibl. 2020. 'What Content to Post? Evaluating the Effectiveness of Facebook Communications in Destinations.' Journal of Destination Marketing \& Management 18:100498. https://doi.org/10.1016/j.jdmm.2020.100498.

Moorthy, K., N. M. Z. N. Salleh, A. X. Jie, C. S. Yi, L. S. Wei, L. Y. Bing, and Y. Z. Ying. 2020. 'Use of Social Media in Planning Domestic Holidays: A Study on Malaysian Millennials.' Millennial Asia. https://doi.org/10.1177 /0976399620938503.

Moric, I. 2013. 'Clusters As a Factor of Rural Tourism Competitiveness: Montenegro Experiences.' Business Systems Research 4(2): 94-107.

Moro, S., and P. Rita. 2018. 'Brand Strategies in Social Media in Hospitality and Tourism.' International Journal of Contemporary Hospitality Management 30:343-64.

Munar, A. M., and J. K. S. Jacobsen. 2014. 'Motivations for Sharing Tourism Experiences through Social Media.' Tourism Management 43:46-54. 
Nayak, B. C., G. K. Nayak, and D. Jena. 2020. 'Social Recognition and Employee Engagement: The Effect of Social Media in Organizations.' International Journal of Engineering Business Management 12:1-12.

Paliokas, I., A. Patenidis, E. Mitsopoulou, C. Tsita, G. Pehlivanides, E. Karyati, S. Tsafaras, E. Stathopoulos, A. Kokkalas, and S. Diplaris. 2020. 'A Gamified Augmented Reality Application for Digital Heritage and Tourism.' Applied Sciences 10 (21): 7868. https://doi.org/10.339o/ app10217868.

Pan, S., J. Lee, and H. Tsai. 2014. 'Travel Photos: Motivations, Image Dimensions, and Affective Qualities of Places.' Tourism Management 40:59-69.

Pavelka, J. P. 2016. 'Smartphone Use During Travel.' Paper presented at the T T R A Canada 2016 Conference, Vail, CO, 14-16 June.

Pawlowska-Legwand, A, and L. Matoga. 2020. 'Disconnect from the Digital World to Reconnect with the Real Life: An Analysis of the Potential for Development of Unplugged Tourism on the Example of Poland.' Tourism Planning \& Development. https://doi.org/10.1080/21568316 .2020 .1842487 .

Peco-Torres, F., A. I. Polo-Pena, and D. M. Frias-Jamilena. 2020. 'Brand Personality in Cultural Tourism through Social Media.' Tourism Review. https://doi.org/10.1108/TR-02-2019-0050.

Renjith, S., A. Sreekumar, and M. Jathavedan. 2020. 'An Extensive Study on the Evolution of Context-Aware Personalized Travel Recommender Systems.' Information Processing \& Management 57 (1). https://doi.org/ 10.1016/j.ipm.2019.102078.

Roblek, V., M. Pejić Bach, M. Meško, and A. Bertoncelj. 2013. 'The Impact of Social Media to Value Added in Knowledge-Based Industries.' Kybernetes 42 (4): 554-68.

Seo, E. J., J. W. Park, and Y. J. Choi. 2020. 'The Effect of Social Media Usage Characteristics on e-wo M, Trust, and Brand Equity: Focusing on Users of Airline Social Media.' Sustainability 12 (4). https://doi.org/10.339o/ su12041691.

Sotiriadis, M. D. 2017. 'Sharing Tourism Experiences in Social Media: A Literature Review and a Set of Suggested Business Strategies.' International Journal of Contemporary Hospitality Management 29 (1): 179-225.

Tan, G. W. H., V. H. Lee, B. Lin, and K. B. Ooi. 2017. 'Mobile Applications in Tourism: The Future of the Tourism Industry?' Industrial Management \& Data Systems 117 (3): 560-81.

Tang, J., and H. Liu. 2015. 'Trust in Social Media.' In Synthesis Lectures on Information Security, Privacy, and Trust, edited by E. Bertino and R. Sandhu, 1-10. San Rafael, cA: Morgan \& Claypool.

Taylor, D. G. 2020. 'Putting the "Self" in Selfies: How Narcissism, Envy 
and Self-Promotion Motivate Sharing of Travel Photos through Social Media.' Journal of Travel \& Tourism Marketing 37 (1): 64-77.

Thinkwithgoogle. 2016. 'Travel Infographic: How Mobile Shapes the Customer Journey.' https://www.thinkwithgoogle.com/consumer-insights/ travel-infographic-mobile-shapes-customer-journey/.

Tomičić Furjan, M., K. Tomičić-Pupek, and I. Pihir. 2020. 'Understanding Digital Transformation Initiatives: Case Studies Analysis.' Business Systems Research: International Journal of the Society for Advancing Innovation and Research in Economy 11 (1): 125-41.

Tourwriter. 2020. 'The Future of Tourism: Travel Trends for 2021 and Beyond' https://www.tourwriter.com/travel-software-blog/future -tourism-2021/.

Travelers Today. 2019. 'Pros and Cons of Smartphones During Travel.' https://www.travelerstoday.com/articles/48598/20191014/pros-and -cons-of-smartphones-during-travel.html.

Usakli, A., B. Koc, and S. Sonmez. 2017. 'How "Social” Are Destinations? Examining European D мо Social Media Usage.' Journal of Destination Marketing \& Management 6 (2): 36-149.

Világgazdaság. (2020). 'A hároméves gyerekek fele már okoseszközöket használ.' https://www.vg.hu/kozelet/kozeleti-hirek/a-haromeves -gyerekek-fele-mar-okoseszkozoket-hasznal-2041725/.

Wang, D., S. Park, and D. R. Fesenmaier. 2012. 'The Role of Smartphones in Mediating the Touristic Experience.' Journal of Travel Research 51 (4): 371-87.

Wang, D., Z. Xiang, and D. R. Fesenmaier. 2016. 'Smartphone Use in Everyday Life and Travel.' Journal of Travel Research 55 (1): 52-63.

Wilcockson, T. D. W., A. M. Osborne, and D. A. Ellis. 2019. 'Digital Detox: The Effect of Smartphone Abstinence on Mood, Anxiety, and Craving.' Addictive Behaviors 99:1-4.

Wilkinson, L. 2013. 'Multidimensional Scaling.' http://cda.psych.uiuc.edu/ multivariate_fall_2013/systat_scaling_manual.pdf.

Woodside, A. G., and Lysonski, S. 1989. 'A General Model of Traveller Destination Choice.' Journal of Travel Research 27 (4): 8-14.

Yang, F. X., and I. A. Wong. 2020. 'The Social Crisis Aftermath: Tourist Well-Being During the CoviD-19 Outbreak.' Journal of Sustainable Tourism. https://doi.org/10.108o/o9669582.2020.1843047.

Yang, H. 2013. 'Bon Appétit for Apps: Young American Consumers Acceptance of Mobile Applications.' Journal of Computer Information Systems 53 (3): 85-96.

Yu, C. E., S. Y. Xie, and J. Wen. 2020. 'Coloring the Destination: The Role of Color Psychology on Instagram.' Tourism Management 80:104110. 



\section{Global Transition to the Subscription}

\section{Economy: Literature Review on Business Model Changes in the Media Landscape}

\author{
Alenka Lena Klopčič \\ Montel Energetika.net, Slovenia \\ alenka-lena.klopcic@energetika.net \\ Jana Hojnik \\ University of Primorska, Slovenia \\ jana.hojnik@fm-kp.si
}

\author{
Štefan Bojnec \\ University of Primorska, Slovenia \\ stefan.bojnec@fm-kp.si \\ Drago Papler \\ University of Primorska, Slovenia \\ drago.papler@guest.arnes.si
}

The business models of media corporations and organisations have undergone a pronounced transition that has resulted in significant change in the last decade, shifting from a model based on advertising revenue and printed copy circulation to a subscription-based model. As this article shows, legacy media is currently experimenting with 'various mixes of paywalls.' Among the models that media companies are switching to is the subscription economy model, i.e. the practice of charging audiences for access to online content which, until recently, was unlocked and/or freely available. Incidentally, the collapse of the 'advertiser model', together with the consequences of the global recession, has brought about significant economic uncertainty for traditional media, pushing it to seek new business strategies for sustainable journalism, while also triggering a reflection on the overall future of media. The aim of this article is to delineate and present the actual changes in the media landscape in relation to subscription economy based on a literature review. Thus, we conducted a systematic literature review including terms as follows: 'subscription economy,' 'digital media,' 'theory of decision' and 'motivation theory', which yielded 145 results of relevant scientific and research articles published in the last 15 years. The main findings revealed that the media landscape is changing rapidly, in particular in terms of the new digital tools being developed and implemented, and accordingly there is rapid growth in the 'non-conventional' competition to the conventional media, new generations' needs and their behaviour, and the urgent need for various new business models.

Key Words: subscription economy, digital media, theory of decision, motivational theory

JEL Classification: L82, L86

(co) [BYSA https://doi.org/10.26493/1854-6935.18.323-348 


\section{Introduction}

The business models of media corporations and organisations have undergone significant change in the last decade - due also to increasing digitalisation, which drives companies to digitalise and consequently internationalise their processes (Ojala, Evers, and Rialp 2018) - shifting from a model based on advertising revenue and printed copy circulation to a subscription-based model.

Subscription economy, which Ritter and Schanz (2019) consider to be a part of the sharing economy (a crucial part of the transition to sustainability), refers mainly to the practice of charging audiences for access to online content, which, until recently, was unlocked/freely available (Kammer et al. 2015), transforming readers into users. This could be connected to the finding of some scholars, specifically Kim, Jeong, and Ghani (2014), who in their work prove to some extent that relevant news is closely related to stock price movements in the market (Besimi et al. 2019), which could be understood as meaning that new-age readers use news to follow the economic information needed for their work.

The collapse of the 'advertiser model,' along with the consequences of the global recession, has brought about significant economic uncertainty for traditional media, pushing it to seek out new business strategies for sustainable journalism, while also triggering a reflection on the future of media (Franklin 2014).

Since no business model seems to be able to generate reliable revenue streams for online news services, many publishers turn to the subscription model as a last resort for survival (Chyi 2009). This raises the question posed in Alexander Manu's Transforming Organizations for the Subscription Economy: Starting from Scratch (2017): 'If you were designing your organization today, how would you design it? In other words, how would you create the future from the ingredients of the present alone?'

Furthermore, there are two modes of thought according to Kahneman (2012): system 1, which is fast, instinctive and emotional, and system 2, which is slower, more deliberate and more logical. Kahneman argues that our decisions, be it everyday decisions or more demanding cognitive processes, such as long-term planning of important home or work strategies, come from the intertwining of these to modes of thought.

According to Thaler (2019), behavioural economics begin with simple observation and continue with data gathering, so in this article, we present an overview of previous research in the field of subscription econ- 
omy, digital media, theory of decision and motivational theory, in order to illustrate the changes in the media landscape in relation to subscription economy, which is recognised as a fundamental business model for future specialised digital media.

The emerging present is a rapidly changing context for existing organizations, especially in segments of the market where online behavior is replacing physical proximity, and users engage with digital platforms to acquire products and services. These platforms allow users to behave, to leave a mark and to participate in the community of others, which are the values that the people are looking for now (Manu 2017).

This brings us to our main research question, which is as follows: How and what changes have occurred in the media landscape and how have these changes affected business models? The aim of this article is to offer a systematic literature review that will offer answers to the above questions. Additionally, it aims to present the actual changes in the media landscape due to the subscription economy.

\section{Methodology}

For the purpose of this article, we conducted a systematic literature review. In order to find relevant scientific articles, we used the Science Direct database (https://www.sciencedirect.com), which widely supports the subject. Using the keyword 'theory of decision' produced 615,194 hits, using the keyword 'digital media' produced 180,290 hits, and using the keyword 'subscription economy' produced 10,151 hits (the searches were conducted between 9 and 24 November 2020). When we entered 'subscription economy' AND 'digital media' AND 'theory of decision' into the search bar, there were 808 results.

In order to solidify the previous research on the subject, we added the keyword 'motivation theory', resulting in the search term: 'subscription economy' AND 'digital media' AND 'theory of decision' AND 'motivation theory.' This search produced 145 results of relevant scientific and research articles. Our aim was to gain the most up-to-date and relevant insight into the field, which we examined in detail, focusing on the papers whose date of publication did not precede 2004, so those published in the last 15 years. We thus focused on the period between 2004 and the time of our searches (9-24 November 2020).

We present the research in the same order as given in the Science Direct database. We observed that the largest number of publications was found in the Journal of Cleaner Production (7) and Information \& Management 
(7), followed by the International Journal of Research in Marketing (3), the Journal of Retailing and Consumer Services (3), Futures (3) and the International Journal of Research in Marketing (3), whereas the rest of the journals each feature one article from the selection of our results (see table 1 in the appendix).

\section{Results and Discussion}

Subscription economy and subscription services, two elements of the sharing economy which is a crucial part of the transition to sustainability (Ritter and Schanz 2019), are at the heart of some of the key findings of this review of previous research. As noted by Kumar, Lahiri, and Dogan (2019), 'sharing economy services are mostly adopted by Generation Y, whereas other generations are still in the early phase of adoption,' so it would make sense to invest in the 'relationship between sharing economy firms (service enablers) and customers.' Additionally, Liu et al. (2019) argue that 'entering the third decade of the new millennium,' the millennial generation, which is 'in substantive ways unlike all earlier generations', is entering its most productive stage of life, so the authors 'urge researchers to explore the unique characteristics of millennial entrepreneurs, their influence on entrepreneurial motivation, orientation, opportunity discovery and exploitation process and the global ambition of their entrepreneurial ventures.'

Additionally, in our review, we often come upon the concepts of circular economy and digital intermediation - also in relation to branding (Gielens and Steenkamp 2019) - as well as information economy, where personal data is the most valuable asset (Spiekermann and Novotny 2015). According to Rhue and Sundararajan (2014), different digital technologies have varying effects on individual freedom while affecting its diffusion via different political networks, and that the related changes in civil liberties can be affected by both media freedom and internal political institutions. This provides a basis for further exploration of the changes in the media landscape in relation to subscription economy.

While Venkatesh and Chatterjee (2006) argue that online content effectively complements printed content and that the wider the product line, the higher the prices of individual offers, Hong, Nam, and Kim (2018) note that once an online portal becomes a platform for the distribution of news to users, a conflict arises between the portal and newspaper companies regarding the value of the content provided by one and the other.

Furthermore, as Chyi (2009) found in her empirical study on the via- 
bility of the subscription model and willingness to pay for online news, since 'no business models seem to generate reliable revenue streams for online news services, many publishers see the subscription model as a last resort for survival although little evidence suggests users are ready to pay for online news at this moment.' The author discovered, on the basis of a random-sample telephone survey of 853 Hong Kong residents, that 'very few users actually responded to paid content and most had no intent to pay in the future.' Moreover, regression analysis also revealed that age and newspaper use are related to paying intent, while income is not. Chyi (2009) therefore urges publishers to consider the economic implications before adopting the subscription model.

However, let us allow for the possibility that the social mindset, that is, the current mentality and stance of online users will change over the years, driven by the increasing popularisation of digital culture. After all, digital culture empowers people to deliver results faster, whereas companies risk transformation failure by ignoring it (Hemerling et al. 2018). Additionally, according to Lokuge et al. (2019), the emergence and proliferation of digital technologies could increase the innovation potential of most organizations.

As noted by Kammer et al. (2015) in their research article, 'after more than a decade of giving online news away for free, legacy newspaper organisations in many Western countries have recently begun charging audiences for access to online journalistic content.' Focusing empirically on the case of Denmark, the article uses one survey $(n=1054)$ and two focus groups to examine the audiences' attitudes toward paying for online news. The analysis shows that the audiences' general principles regarding paying for online news have a greater effect on their willingness to pay than the size of the subscription fee. Furthermore, the analysis reveals that younger audiences' willingness to pay increases if they can combine content from different news providers, thus individualising their news products. According to the researchers, this can have practical implications - either by offering a way forward for economically challenged legacy newspaper organisations, or by compromising the democratic ideals of journalism (Kammer et al. 2015). This has also been observed by Pickard and Williams (2014), who say that paywalls or the subscription model can contribute to a 'democratic deficit' by using 'the ability to pay to gatekeep exclusion from quality news.'

A problem also arises when there is no discernible improvement ('no added value') in the quality or uniqueness of the published - and paid for - news stories compared to those that are freely available else- 
where online, making the rationale for 'paying for news' inexplicable, as noted by Frankin (2014) in 'The Future of Journalism.' Franklin (2014) also finds that there is no real agreement within the journalism industry or the academy about the appropriateness of particular alternatives to the advertiser model, as legacy media experiment with various mixes of pay walls (Myllylahti 2013; Pickard and Williams 2014), advertising on mobile devices ( $\mathrm{Nel}$ and Westlund 2012; Reynolds 2014), selling newspaper apps (Franklin 2014), crowdfunding, crowdsourcing and co-creation (Aitamurto 2013), hyperlocal business models (van Kerkhoven and Bakker 2014), not-for-profit models which secure funding for journalistic projects from international non-governmental organizations (NGOS), private foundations and think-tanks (Requejo-Alemán and Lugo-Ocando 2014), using a mix of public funding, sales and subscription to finance minority language journalism (Zabaleta et al. 2014), efforts to monetise hyperlinks (Doherty 2014) and even the expansive provision of machine- or robot-written news (Clerwall 2014).

However, according to Franklin (2014), Picard (2014) remains optimistic, celebrating the diversity of business models and revenue streams. He concludes (Franklin 2014, 484):

What is clear is that news providers are becoming less dependent on any one form of funding than they have been for about 150 years. Multiple revenue streams from readers and advertisers, from events and e-commerce, from foundations and sponsors, and from related commercial services, such as web hosting and advertising services are all contributing income. It is too early to assess fully the efficacy and sustainability of these sources, but they provide reason to believe that workable new business models are appearing in news provision.

Additionally, Peekhaus and Proferes (2016) find that open-access scholarly publishing has grown steadily in academia in the past few decades as an alternative to traditional, subscription-based journal publishing, whereas Boissy et al. (2012), while examining whether publishing as a 'big deal' is dying, found that most participants (of their survey) believe that it is not dead yet, whereas some think it may never die completely.

\section{Conclusion}

In our literature review, we focused on conducted research on subscription economy, the theory of decision and digital media. The aim of this paper was to search and present what research in the field of the subscrip- 
tion economy, digital media, the theory of decision and motivational theory has revealed so far. When conducting further research, however, it might be useful to expand our thinking and relate it to Kuzmanić (2019), who states: 'The problem of our time in the sense that our current problems and crises are not at all possible to seriously grasp in economic terms, but primarily in the chrematistic categories and the possibilities of that new paradigm of thinking.

Based on the conducted literature review, we reviewed in more detail 145 papers that focus on the subscription economy and users' behaviour in terms of digital media. The main findings revealed that the media landscape is changing rapidly, in particular in terms of the new digital tools being developed and implemented, and accordingly there is rapid growth in the 'non-conventional' competition to the conventional media, new generations' needs and their behaviour, and the urgent need for various new business models. In addition, we also learned that search engines, such as Google and Yahoo! Search, are more than just portals and information tools. They are - and probably will be for a while more - the agents of transformation in the changing media landscape, which actually make the business environment more transparent and competitive (Rangaswamy, Giles, and Seres 2009), with blogs also playing a part (Wohlmann 2012).

With all this in mind, as well as the findings of the literature review, including behavioural patterns and new generations, as mentioned by some researchers (Kumar, Lahiri, and Dogan 2019; Liu et al. 2019), even bloggers (Wohlmann 2012), we conclude by quoting the well-influenced thinker and author Rifkin (2007) who once wrote: 'Science explores, technology executes, man conforms,' and so the fundamental conclusion of this paper, in which we examined the findings of previous research in the field of the subscription economy, digital media, the theory of decision and the motivational theory, is that the age of media transformation is already well ongoing.

\section{References}

Aapaoja, A., J. Kostiainen, Zulkarnain, and P. Leviäkangas. 2017. 'i Ts Service Platform: In Search of Working Business Models and Ecosystem.' Transportation Research Procedia 25:1781-95.

Abu Bakar, M. S., and R. Bidin. 2014. 'Technology Acceptance and Purchase Intention towards Movie Mobile Advertising among Youth in Malaysia.' Procedia: Social and Behavioral Sciences 130:558-67. 
Acheson, K., and C. Maule. 2006. 'Culture in International Trade.' In Handbook of the Economics of Art and Culture, vol. 1, edited by V. A. Ginsburgh and D. Throsby, 1141-82. Oxford: Elsevier.

Aczel, J. C., S. R. Peake, and P. Hardy. 2008. 'Designing Capacity-Building in e-Learning Expertise: Challenges and Strategies.' Computers \& Education 50 (2): 499-510.

Aguiar, L., and B. Martens. 2016. 'Digital Music Consumption on the Internet: Evidence from Clickstream Data.' Information Economics and Policy 34:27-43.

Aitamurto, T. 2013. 'Balancing Between Open and Closed: Co-Creation in Magazine Journalism.' Digital Journalism 1 (2): 229-51.

Al-Debei, M. M., and E. Al-Lozi. 2014. 'Explaining and Predicting the Adoption Intention of Mobile Data Services: A Value-Based Approach.' Computers in Human Behavior 35:326-38.

Alderete, M. V. 2019. 'Examining the Drivers of Internet Use among the Poor: The Case of Bahía Blanca city in Argentina.' Technology in Society 59:101179. https://doi.org/10.1016/j.techsoc.2019.101179

Aleem, S., L. F. Capretz, and F. Ahmed. 2016. 'Empirical Investigation of Key Business Factors for Digital Game Performance.' Entertainment Computing 13:25-36.

Alpar, P., T. H. Engler, and M. Schulz. 2015. 'Influence of Social Software Features on the Reuse of Business Intelligence Reports.' Information Processing \& Management 51 (3): 235-51.

Arena, M., G. Azzone, and F. Mapelli. 2018. 'What Drives the Evolution of Corporate Social Responsibility Strategies? An Institutional Logics Perspective.' Journal of Cleaner Production 171:345-55.

Bagwell, K. 2007. 'The Economic Analysis of Advertising.' Handbook of Industrial Organization 3:1701-844.

Baron, N. S. 2004. 'Rethinking Written Culture.' Language Sciences 26 (1): 57-96.

Bartikowski, B., M. Laroche, A. Jamal, and Z. Yang. 2018. 'The Type-ofInternet-Access Digital Divide and the Well-Being of Ethnic Minority and Majority Consumers: A Multi-Country Investigation.' Journal of Business Research 82:373-380.

Bartolini, C., C. Santos, and C. Ullrich. 2018. 'Property and the Cloud.' Computer Law \& Security Review 34 (2): 358-90.

Belleflamme, P., N. Omrani, and M. Peitz. 2015. 'The Economics of Crowdfunding Platforms.' Information Economics and Policy 33:11-28.

Beltagui, A., N. Kunz, and S. Gold. 2019. 'The Role of 3D Printing and Open Design on Adoption of Socially Sustainable Supply Chain Innovation.' International Journal of Production Economics 221 (c): 107462. https://doi.org/10.1016/j.ijpe.2019.07.035 
Benlian, A., and T. Hess. 2011. 'Opportunities and Risks of Software-asa-Service: Findings from a Survey of I T Executives.' Decision Support Systems 52 (1): 232-46.

Besimi, A., Z. Dika, V. Shehu, and M. Selimi. 2019. 'Applied Text-Mining Algorithms for Stock Price Prediction Based on Financial News Articles.' Managing Global Transitions 17 (4): 335-51.

Binder, C. C. 2016. 'Estimation of Historical Inflation Expectations.' Explorations in Economic History 61:1-31.

Bischof, S. F., T. M. Boettger, and T. Rudolph. 2020. 'Curated Subscription Commerce: A Theoretical Conceptualization.' Journal of Retailing and Consumer Services 54:101822. https://doi.org/o.1016/j.jretconser.2019 .04 .019

Boccaletti, S., G. Bianconi, R. Criado, C. I. del Genio, and M. Zanin. 2014. 'The Structure and Dynamics of Multilayer Networks.' Physics Reports 544 (1): 1-122.

Boissy, R. W., T. N. Taylor, C. M. Stamison, K. S. Henderson, and A. D. Linoski. 2012. 'Is the Big Deal Dying?' Serials Review 38 (1): 36-45.

Borés, C., C. Saurina, and R. Torres. 2003. 'Technological Convergence: A Strategic Perspective.' Technovation 23 (1): 1-13.

Browder, R. E., H. E. Aldrich, and S. W. Bradley. 2019. 'The Emergence of the Maker Movement: Implications for Entrepreneurship Research.' Journal of Business Venturing 34 (3): 459-76.

Brown, M., S. Woodhouse, and F. Sioshansi. 2019. 'Digitalization of Energy' In Consumer, Prosumer, Prosumager: How Service Innovations will Disrupt the Utility Business Model, edited by F. Shioshansi, 3-25. London: Academic Press.

Brydon, M. and A. R. Vining. 2006. 'Understanding the Failure of Internal Knowledge Markets: A Framework for Diagnosis and Improvement.' Information \& Management 43 (8): 964-74.

Calvo-Porral, C., A. Faíña-Medín, and M. Nieto-Mengotti. 2017. 'Exploring Technology Satisfaction: An Approach through the Flow Experience.' Computers in Human Behavior 66:400-8.

Carbonell, J., A. Sánchez-Esguevillas, and B. Carro. 2015. 'Assessing Emerging Issues. The External and Internal Approach.' Futures 73:12-21.

Chik, W. B. 2011. 'The Google Conundrum: Perpetrator or Facilitator on the Net? - Forging a Fair Copyright Framework of Rights, Liability and Responsibility in Response to Search Engine 2.0 - Part 2: The Google Books Search Project.' Computer Law \& Security Review 27 (4): 331-47.

Chipidza, W., and D. Leidner. 2019. 'A Review of the IC T-Enabled Development Literature: Towards a Power Parity Theory of IC T 4D.' The Journal of Strategic Information Systems 28 (2): 145-74.

Chyi, H. I. 2009. 'Willingness to Pay for Online News: An Empirical Study 
on the Viability of the Subscription Model.' Journal of Media Economics 18 (2): $131-42$.

Clemons, E. K. 2009. 'The Complex Problem of Monetizing Virtual Electronic Social Networks.' Decision Support Systems 48 (1): 46-56.

Clerwall, C. 2014. 'Enter the Robot Journalist.' Journalism Practise 8 (5): 519-31.

Currie, W. L. 2012. 'TE M PES T: An Integrative Model for Health Technology Assessment.' Health Policy and Technology 1 (1): 35-49.

Das, G. G., and I. Drine. 2020. 'Distance from the Technology Frontier: How Could Africa Catch-Up via Socio-Institutional Factors and $\mathrm{Hu}-$ man Capital?' Technological Forecasting and Social Change 150:119755. https://doi.org/10.1016/j.techfore.2019.119755

DeVoss, D. N., and J. E. Porter. 2006. 'Why Napster Matters to Writing: Filesharing as a New Ethic of Digital Delivery. Computers and Composition 23 (2): 178-210.

Ding, Y. 2019. 'Looking Forward: The Role of Hope in Information System Continuance.' Computers in Human Behavior 91:127-37.

Doherty, S. 2014. 'Hypertext and Journalism - Paths for Future Research.' Digital Journalism 2 (2):124-39.

Drachen, A., J. Riley, S. Baskin, and D. Klabjan. 2014. 'Going out of Business: Auction House Behavior in the Massively Multi-player Online Game Glitch.' Entertainment Computing 5 (4): 219-32.

Fedorowicz, J., S. Sawyer, C. B. Williams, M. L. Markus, and R. Schrier. 2014. 'Design Observations for Interagency Collaboration.' Government Information Quarterly 31 (2): 302-16.

Ferranti, F., R. Beunen, P. Vericat, and M. Geitzenauer. 2019. 'The Fitness Check of the Birds and Habitats Directives: A Discourse Analysis of Stakeholders Perspectives.' Journal for Nature Conservation 47:103-9.

Franklin, B. 2014. 'The Future of Journalism: In an Age of Digital Media and Economic Uncertainty.' Journalism Studies 15 (5): 481-99.

Funk, D. C. 2017. 'Introducing a Sport Experience Design (sx) Framework for Sport Consumer Behaviour Research.' Sport Management Review 20 (2): $145-58$.

Galloway, C. 2017. 'Blink and They're Gone: PR and the Battle for Attention.' Public Relations Review 43 (5): 969-77.

Gielens, K., and J.-B. E. M. Steenkamp. 2019. 'Branding in the Era of Digital (Dis)Intermediation.' International Journal of Research in Marketing 36 (3): 367-84.

Godoe, H., and T. B. Hansen. 2009. 'Technological Regimes in M-Commerce: Convergence as a Barrier to Diffusion and Entrepreneurship?' Telecommunications Policy 33 (1-2): 19-28.

Goldfarb, A., and C. Tucker. 2019. 'Digital Marketing.' In Handbook of the 
Economics of Marketing, vol. 1, edited by J.-P. Dube and P. Rossi, 25990. San Diego, c A: Elsevier Science \& Technology.

Grajek, M., and T. Kretschmer. 2009. 'Usage and Diffusion of Cellular Telephony, 1998-2004.' International Journal of Industrial Organization 27 (2): 238-49.

Green, T., and J. Peloza. 2015. 'How Did the Recession Change the Communication of Corporate Social Responsibility Activities?' Long Range Planning 48 (2): 108-22.

Guo, J., and H. Bouwman. 2016. 'An Analytical Framework for an MPayment Ecosystem: A Merchants? Perspective.' Telecommunications Policy 40 (2-3): 147-67.

Gupta, P., A. Seetharaman, and J. R. Raj. 2013. 'The Usage and Adoption of cloud computing by Small and Medium Businesses.' International Journal of Information Management 33 (5): 861-74.

Harris, I., Y. Wang, and H. Wang. 2015. 'І І т in Multimodal Transport and Technological Trends: Unleashing Potential for the Future.' International Journal of Production Economics 159:88-103.

Hemerling, J., J. Kilmann, M. Danoesastro, L. Stutts, and C. Ahern. 2018. 'It's Not a Digital Transformation Without a Digital Culture.' Boston Consulting Group. https://www.bcg.com/publications/2018/not -digital-transformation-without-digital-culture.aspx.

Hinson, R. 2010. 'The Value Chain and E-Business in Exporting: Case Studies from Ghanas Non-Traditional Export (NTE) Sector.' Telematics and Informatics 27 (3): 323-40.

Holsapple, C. W., S.-H. Hsiao, and R. Pakath. 2018. 'Business Social Media Analytics: Characterization and Conceptual Framework.' Decision Support Systems 110:32-45.

Hong, A., C. Nam, and S. Kim. 2018. 'A Customer-Based Indirect Approach to Determine the Value of News Provided to Internet Portals in Korea.' Telematics and Informatics 35 (6): 1718-32.

Howard, M., P. Vidgen, and P. Powell. 2006. 'Automotive e-hubs: Exploring Motivations and Barriers to Collaboration and Interaction. The Journal of Strategic Information Systems 15 (1): 51-75.

Hsiaofen Chen, J., and J.-R. Fu. 2018. 'On the Effects of Perceived Value in the Mobile Moment.' Electronic Commerce Research and Applications 27:118-28.

Hutchins, B. 2016. 'The More Things Change, The More They Stay the Same: Path Dependency, Sports Content, and the Suppression of Innovation in Mobile Television.' Telematics and Informatics 33 (2): 703-10. Ivaturi, K., and C. Chua. 2019. 'Framing Norms in Online Communities.' Information \& Management 56 (1): 15-27.

Jang, D., J. Eom, M. G. Kim, and J. J. Rho. 2015. 'Demand Responses of 
Korean Commercial and Industrial Businesses to Critical Peak Pricing of Electricity.' Journal of Cleaner Production 90:275-90.

Jansen, S. 2020. 'A Focus Area Maturity Model for Software Ecosystem Governance.' Information and Software Technology 118:106219. https://doi.org/10.1016/j.infsof.2019.106219

Johnson, I. M. 2005. 'The Impact on Libraries and Archives in Iraq of War and Looting in 2003 - A Preliminary Assessment of the Damage and Subsequent Reconstruction Efforts.' The International Information \& Library Review 37(3): 209-71.

Kabbiri, R., M. Dora, V. Kumar, G. Elepu, and X. Gellynck. 2018. 'Mobile Phone Adoption in Agri-Food Sector: Are Farmers in Sub-Saharan Africa Connected?' Technological Forecasting and Social Change 131:253 -61 .

Kahneman, D. 2012. Thinking, Fast and Slow. London: Penguin.

Kammer, A., M. Boeck, J. V. Hansen, and L. J. Hadberg Hauschild. 2015. 'The Free-to-Fee Transition: Audiences Attitudes toward Paying for Online News.' Journal of Media Business Studies 12 (2): 107-20.

Kang, J.-S., and S. Downing. 2015. 'Keystone Effect on Entry into TwoSided Markets: An Analysis of the Market Entry of WiMax.' Technological Forecasting and Social Change 94:170-86.

Kannan, P. K., and A. L. Hongshuang. 2017. 'Digital Marketing: A Framework, Review and Research Agenda.' International Journal of Research in Marketing 34 (1): 22-45.

Keller, J. C., S. E. Lloyd, and M. M. Bell. 2015. 'Creating and Consuming the Heartland: Symbolic Boundaries in Representations of Femininity and Rurality in U.S. Magazines.' Journal of Rural Studies 42: 133-43.

Kim, Y., S. R. Jeong, and I. Ghani. 2014. 'Text Opinion Mining to Analyze News for Stock Market Prediction.' International Journal of Advances In Soft Computing and its Application 6 (1): 1-13.

Kirs P., and K. Bagchi. 2012. 'The Impact of Trust and Changes in trust: A National Comparison of Individual Adoptions of Information and Communication Technologies and Related Phenomenon.' International Journal of Information Management 32 (5): 431-41.

Konietzny, J., A. Caruana, and M. L. Cassar. 2018. 'Fun and Fair, and I Don't Care: The Role of Enjoyment, Fairness and Subjective Norms on Online Gambling Intentions.' Journal of Retailing and Consumer Services 44:91-99.

Kumar, V., A. Lahir, and O. B. Dogan. 2019. 'A Strategic Framework for a Profitable Business Model in the Sharing Economy'. Industrial Marketing Management 69:147-6o.

Kuzmanić, T. 2019. 'Aristotles Chrematistike and the Current Post-Economy'. Managing Global Transitions 17 (2): 129-48. 
Laurent, M., J. Denouël, C. Levallois-Barth, and P. Waelbroeck. 2015. 'Digital Identity'. In Digital Identity Management, edited by M. Laurent and S. Bouzefrane, 1-45. London: ISTE.

Lee, U., K. Han, H. Cho, K.-M. Chung, and J. M. Carroll. 2019. 'Intelligent Positive Computing with Mobile, Wearable, and IoT Devices: Literature Review and Research Directions.' Ad Hoc Networks 83:8-24.

Li, C., S. Guo, C. L. Wang, and J. Zhang. 2019. 'Veni, Vidi, Vici: The Impact of Social Media on Virtual Acculturation in Tourism Context.' Technological Forecasting and Social Change 145:513-522.

Li, Z., H. Zhang, L. O’Brien, S. Jiang, and R. Ranjan. 2016. 'Spot Pricing in the Cloud Ecosystem: A Comparative Investigation.' Journal of Systems and Software 114 (1):1-19.

Liburd, J. H. 2012. 'Tourism Research 2.o.' Annals of Tourism Research 39 (2): 883-907.

Liu, J., Y. Zhu, M. G. Serapio, and S. T. Cavusgil. 2019. 'The New Generation of Millennial Entrepreneurs: A Review and Call for Research.' International Business Review 28 (5): 101581. https://doi.org/10.1016/j.ibusrev .2019.05.001

Lokuge, S., D. Sedera, V. Grover, and X. Dongming. 2019. 'Organizational Readiness for Digital Innovation: Development and Empirical Calibration of a Construct.' Information \& Management 56 (3):445-61.

Lyons, G., P. Hammond, and K. Mackay. 2019. 'The Importance of User Perspective in the Evolution of MaaS.' Transportation Research Part A: Policy and Practice 131:20-34.

Mabon, L. 2020. 'Making Climate Information Services Accessible to Communities: What Can We Learn from Environmental Risk Communication Research?' Urban Climate 31:100537. https://doi.org/10 $.1016 /$ j.uclim.2019.100537

Mackay, M., S. M. Jennings, I. van Putten, H. Sibly, and S. Yamazaki. 2018. 'When Push Comes to Shove in Recreational Fishing Compliance, Think Nudge.' Marine Policy 95:256-66.

Mahmood, A., and C. Sismeiro. 2017. 'Will They Come and Will They Stay? Online Social Networks and News Consumption on External Websites. Journal of Interactive Marketing 37:117-32.

Majumdar, S. K. 2008. 'Broadband Adoption, Jobs and Wages in the us Telecommunications Industry'. Telecommunications Policy 32 (9-10): 587-99.

Manu, A. 2017. Transforming Organizations for the Subscription Economy: Starting from Scratch. London: Routledge.

Marchand, A., and T. Hennig-Thurau. 2013. 'Value Creation in the Video Game Industry: Industry Economics, Consumer Benefits, and Research Opportunities.' Journal of Interactive Marketing 27 (3): 141-57. 
Martinez Dy, A. 2019. 'Levelling the Playing Field? Towards a CriticalSocial Perspective on Digital Entrepreneurship.' Futures 102438. https:// doi.org/10.1016/j.futures.2019.102438

Mäntymäki, M., and J. Salo. 2015. 'Why do Teens Spend Real Money in Virtual Worlds? A Consumption Values and Developmental Psychology Perspective on Virtual Consumption.' International Journal of Information Management 35 (1): 124-34.

McClellan, S., S. Low, and W.-T. Tan. 2004. 'Disruptive Technologies and Their Affect on Global Telecommunications.' Advances in Computers 61:199-273.

Meade, N., and T. Islam. 2015. 'Forecasting in Telecommunications and IC T - A Review.' International Journal of Forecasting 31 (4): 1105-26.

Menell, P. S., and S. Scotchmer. 2007. 'Intellectual Property Law. In Handbook of Law and Economics, vol. 2, edited by A. M. Polinsky and S. Shavell, 1473-570. Amsterdam: Elsevier.

Mesak, H. I., A. Bari, B. J. Babin, L. M. Birou, and A. Jurkus. 2011. 'Optimum Advertising Policy Over Time for Subscriber Service Innovations in the Presence of service Cost Learning and Customers Disadoption.' European Journal of Operational Research 211 (3): 642-49.

Messinger, P. R., E. Stroulia, K. Lyons, M. Bone, and S. Perelgut. 2009. 'Virtual worlds - Past, Present, and Future: New Directions in Social Computing.' Decision Support Systems 47 (3): 204-28.

Mohr, I. 2007. 'Buzz Marketing for Movies.' Business Horizons 50 (5): 395403.

Myllylahti, M. 2013. 'Newspaper Paywalls - The Hype and the Reality.' Digital Journalism 2 (2): 179-94.

Nakano, S., and F. N. Kondo. 2018. 'Customer Segmentation with Purchase Channels and Media Touchpoints Using Single Source Panel Data.' Journal of Retailing and Consumer Services 41:142-52.

Nel, F., and O. Westlund. 2012. 'The 4 C's of Mobile News: Channels, Conversation, Content and Commerce.' Journalism Practice 6 (5-6): 395415 .

Netter, S., E. R. G. Pedersen, and F. Lüdeke-Freund. 2019. 'Sharing Economy Revisited: Towards a New Framework for Understanding Sharing Models.' Journal of Cleaner Production 221:224-33.

Nishida, T., J. B. Pick, and A. Sarkar. 2014. 'Japan's Prefectural Digital Divide: A Multivariate and Spatial Analysis.' Telecommunications Policy 38 (11): 992-1010.

Ojala, A., N. Evers, and A. Rialp. 2018. 'Extending the International New Venture Phenomenon to digital Platform Providers: A Longitudinal Case Study. Journal of World Business 53 (5): 725-39.

Ojo, A., T. Janowski, and J. Awotwi. 2013. 'Enabling Development through 
Governance and Mobile Technology' Government Information Quarterly 30 (s1): s32-s45.

Ooi, K.-B., J.-J. Sim, K.-T. Yew, and B. Lin. 2011. 'Exploring Factors Influencing Consumers Behavioral Intention to Adopt Broadband in Malaysia.' Computers in Human Behavior 27 (3): 1168-78.

Osman, I. H., A. L. Anouze, Z. Irani, H. Lee, and V. Weerakkody. 2019. 'A Cognitive Analytics Management Framework for the Transformation of Electronic Government Services from Users Perspective to Create Sustainable Shared Values.' European Journal of Operational Research 278 (2): 514-32.

Otto, B., V. Ebner, E. Baghi, and R. M. Bittmann. 2013. 'Toward a Business Model Reference for Interoperability Services.' Computers in Industry 64 (8): 887-97.

Palvia, P., N. Baqir, and H. Nemati. 2018. 'IC T for Socio-Economic Development.' Information \& Management 55 (2): 160-76.

Panda, A., and N. K. Jain. 2018. 'Compulsive Smartphone Usage and Users Ill-Being among Young Indians: Does Personality Matter?' Telematics and Informatics 35 (5): 1355-72.

Park, H., and C. M. Joyner Armstrong. 2019. 'Is Money the Biggest Driver? Uncovering Motives for Engaging in online Collaborative Consumption Retail Models for Apparel.' Journal of Retailing and Consumer Services $51(\mathrm{C}): 42-50$.

Peekhaus, W., and N. Proferes. 2016. 'An Examination of North American Library and Information Studies faculty Perceptions of and Experience with Open-Access Scholarly Publishing.' Library \& Information Science Research 38 (1): 18-29.

Perryer, C., N. A. Celestine, B. Scott-Ladd, C. Leighton. 2016. 'Enhancing Workplace Motivation through Gamification: Transferrable Lessons from Pedagogy' The International Journal of Management Education $14(3): 327-35$.

Phang, D. C. W., K. Wang, Q. Wang, R. J. Kauffman, and M. Naldi. 2019. 'How to Derive Causal Insights for Digital Commerce in China? A Research Commentary on Computational Social Science Methods.' Electronic Commerce Research and Applications 35:100837. https://doi.org/ 10.1016/j.elerap.2019.100837.

Phillips, P. W. B., J.-A. Relf-Eckstein, G. Jobe, and B. Wixted. 2019. 'Configuring the New Digital Landscape in Western Canadian Agriculture.' NJA S: Wageningen Journal of Life Sciences 53 (5): 725-39.

Picard, G. R. 2014. 'Twilight or New Dawn of Journalism: Evidence from the Changing News Ecosystem.' Journalism studies 15 (5): 500-10.

Pickard, V., and A. T. Williams. 2014. 'Salvation or Folly? The Promise and Perils of Digital Paywalls.' Digital Journalism 2 (2): 195-213. 
Pick, J. B., A. Sarkar, and J. Johnson. 2015. 'United States Digital Divide: State Level Analysis of Spatial Clustering and Multivariate Determinants of IC T Utilization.' Socio-Economic Planning Sciences 49:16-32.

Purtova, N. 2009. 'Property Rights in Personal Data: Learning from the American Discourse.' Computer Law \& Security Review 25 (6): 507-21.

Rangaswamy, A., C. L. Giles, and S. Seres. 2009. 'A Strategic Perspective on Search Engines: Thought Candies for Practitioners and Researchers.' Journal of Interactive Marketing 23 (1): 49-6o.

Rhue, L., and A. Sundararajan. 2014. 'Digital Access, Political Networks and the Diffusion of Democracy.' Social Networks 23 (1): 49-6o.

Reed, A., M. R. Forehand, S. Puntoni, and L. Warlop. 2012. Identity-Based Consumer Behavior. International Journal of Research in Marketing 29(4):310-321.

Requejo-Alemán, J. L., and J. Lugo-Ocando. 2014. 'Assessing the Sustainability of Latin American Investigative Non-profit Journalism.' Journalism Studies 15 (5): 522-32.

Reynolds, J. 2014. 'U K Mobile Advertising set to Overtake Newspaper Ad Revenue in 2014.' The Guardian, 10 March. https://www.theguardian .com/media/2014/mar/10/uk-mobile-advertising-overtake-newspaper -revenue.

Rifkin, J. 2007. The End of Work. New York: Penguin.

Ritter, M., and H. Schanz. 2019. 'The Sharing Economy: A Comprehensive Business Model Framework.' Journal of Cleaner Production 213:320-31.

Rossi, E., A. C. Bertassini, C. dos Santos Ferreira, W. A. Neves do Amaral, and A. R. Ometto. 2019. 'Circular Economy Indicators for Organizations Considering Sustainability and Business Models: Plastic, Textile and Electro-Electronic Cases.' Journal of Cleaner Production 247:119137. https://doi.org/10.1016/j.jclepro.2019.119137

Ruotsalainen, J., J. Karjalainen, M. Child, and S. Heinonen. 2017. 'Culture, Values, Lifestyles, and Power in Energy Futures: A Critical Peer-to-Peer Vision for Renewable Energy.' Energy Research \& Social Science 34:23139.

Rymaszewska, A., P. Helo, and A. Gunasekaran. 2017. 'IoT Powered Servitization of Manufacturing - An Exploratory Case Study.' International Journal of Production Economics 192:92-105.

Saavedra, J. L., and A. K. González. 2015. 'w Tp Consumers Key Factors for Local and Regional Newspaper Print Subscription Plans.' Journal of Retailing and Consumer Services 27 (C): 164-69.

Saha, D. 2005. 'Pervasive Computing: A Vision to Realize.' Advances in Computers 64:195-245.

Salehan, M., D. J. Kim, and J.-N. Lee. 2018. 'Are There Any Relationships between Technology and Cultural Values? A Country-Level Trend 
Study of the Association between Information Communication Technology and Cultural Values.' Information \& Management 55 (6): 725-45. Sandvig, C. 2004. 'An Initial Assessment of Cooperative Action in Wi-Fi Networking.' Telecommunications Policy 28 (7-8): 579-602.

Scheaf, D. J., B. C. Davis, J. W. Webb, J. E. Coombs, and G. Holloway. 2018. 'Signals Flexibility and Interaction with Visual Cues: Insights from Crowdfunding.' Journal of Business Venturing 33 (6): 720-41.

Schröder, P., P. Vergragt, H. Szejnwald Brown, L. Dendler, and R. Wennersten. 2019. 'Advancing Sustainable Consumption and Production in Cities - A Transdisciplinary Research and Stakeholder Engagement Framework to Address Consumption-Based Emissions and Impacts.' Journal of Cleaner Production 213:114-25.

Servia-Rodríguez, S., R. P. Díaz-Redondo, A. Fernández-Vilas, Y. BlancoFernánde, and J. J. Pazos-Arias. 2014. 'A Tie Strength Based Model to Socially-Enhance Applications and Its Enabling Implementation: mySocialSphere.' Expert Systems with Applications 41 (5): 2582-94.

Shaffer, V. A., and H. R. Arkes. 2009. 'Preference Reversals in Evaluations of Cash versus Non-Cash Incentives.' Journal of Economic Psychology 30 (6): 859-72.

Shin, D.-H. 2007. 'A Critique of Korean National Information Strategy: Case of National Information Infrastructures.' Government Information Quarterly 24 (3): 624-45.

Shin, D.-H., and J. Jung. 2012. 'Socio-Technical Analysis of Koreas Broadband Convergence Network: Big Plans, Big Projects, Big Prospects?' Telecommunications Policy 36 (7): 579-93.

Shin, D.-H., and S. H. Kweon. 2011. 'Evaluation of Korean Information Infrastructure Policy 2000-2010: Focusing on Broadband Ecosystem Change.' Government Information Quarterly 28 (3): 374-87.

Shukla, P., and J. Drennan. 2018. 'Interactive Effects of Individual- and Group-Level Variables on Virtual Purchase Behavior in Online Communities.' Information \& Management 55 (5): 598-607.

Sim, J.-J., G. Wei-Han Tan, J. C. J. Wong, K.-B. Ooi, and T.-S. Hew. 2014. 'Understanding and Predicting the Motivators of Mobile Music Acceptance - A Multi-Stage Mr A-Artificial Neural Network Approach.' Telematics and Informatics 31 (4): 569-84.

Singh, A., A. Payal, and S. Bharti. 2019. 'A Walkthrough of the Emerging IoT Paradigm: Visualizing inside Functionalities, Key Features, and Open Issues.' Journal of Network and Computer Applications 143:111-51. Sorescu, A., R. T. Frambach, J. Singh, A. Rangaswamy, and C. Bridges. 2011. 'Innovations in Retail Business Models'. Journal of Retailing 87 (s1): s3s16.

Spencer, A. J., D. Buhalis, and M. Moital. 2012. 'A Hierarchical Model of 
Technology Adoption for Small Owner-Managed Travel Firms: An Organizational Decision-Making and Leadership Perspective.' Tourism Management 33 (5): 1195-208.

Spiekermann, S., and A. Novotny. 2015. 'A Vision for Global Privacy Bridges: Technical and Legal Measures for International Data Markets.' Computer Law \& Security Review 31 (2): 181-200.

Stocker, V., and J. Whalley. 2018. 'Speed Isn't Everything: A Multi-Criteria Analysis of the Broadband Consumer Experience in the U K.' Telecommunications Policy 42 (1):1-14.

Suddaby, R., T. Viale, and Y. Gendron. 2016. 'Reflexivity: The Role of Embedded Social Position and Entrepreneurial Social Skill in Processes of Field Level Change.' Research in Organizational Behavior 36:225-45.

Tallberg, M., H. Hämmäinen, J. Töyli, S. Kamppari, and A. Kivi. 2007. 'Impacts of Handset Bundling on Mobile Data Usage: The Case of Finland.' Telecommunications Policy 31 (10-11): 648-59.

Tan, G. W.-H., V-H. Lee, J.-J. Hew, K.-B. Ooi, and L.-W. Wong. 2018. 'The interactive Mobile Social Media Advertising: An Imminent Approach to Advertise Tourism Products and Services?' Telematics and Informatics 35 (8): 2270-88.

Thaler, R. 2019. Nerazumno vedenje: razvoj vedenjske ekonomije. Ljubljana: Umco.

Tomiyama, T., E. Lutters, R. Stark, and M. Abramovici. 2019. 'Development Capabilities for Smart Products.' CIRP Annals 68 (2):727-50.

Turner, P. 2012. 'Regulation of Professional Sport in a Changing Broadcasting Environment: Australian Club and Sport Broadcaster Perspectives.' Sport Management Review 15 (1): 43-59.

Turner, P., and D. Shilbury. 2005. 'Determining the Professional Sport Broadcasting Landscape: An Australian Football Club Perspective.' Sport Management Review 8 (2): 167-93.

Tyce, M. 2020. 'Beyond the Neoliberal-Statist Divide on the Drivers of innovation: A Political Settlements Reading of Kenyas M-Pesa Success Story.' World Development 125:104621. https://doi.org/10.1016/j .worlddev.2019.104621

Van Gorp, A. F., C. F. Maitland, and H. Hanekop. 2006. 'The Broadband Internet Access Market: The Changing Role of is Ps.' Telecommunications Policy 30 (2): 96-111.

Van Kerkhoven, M., and P. Bakker. 2014. 'The Hyperlocal in Practice: Innovation, Creativity and Diversity.' Digital Journalism 2 (3): 296-309.

Venkatesh, R., and R. Chatterjee. 2006. 'Bundling, Unbundling, and Pricing of Multiform Products: The Case of Magazine Content.' Journal of Interactive Marketing 20 (2): 21-40.

Von Krogh, G., and S. Spaeth. 2007. 'The Open Source Software Phe- 
nomenon: Characteristics that Promote Research.' The Journal of Strategic Information Systems 16 (3): 236-53.

Wang, K. 2015. 'Determinants of Mobile Value-Added Service Continuance: The Mediating Role of Service Experience.' Information \& Management 52 (3): 261-74.

Wiener, M., N. Hoßbach, and C. Saunders. 2018. 'Omnichannel Businesses in the Publishing and Retailing Industries: Synergies and Tensions between Coexisting Online and Offline Business Models.' Decision Support Systems 109:15-26.

Wohlmann, A. 2012. 'Let the Countdown Begin - Aging Experiences of Young Adults in Countdown Blogs.' Journal of Aging Studies 26 (1): 90101.

Yang, J., J. G Siri, J. V. Remais, Q. Cheng, and P. Gong. 2018. 'The TsinghuaLancet Commission on Healthy Cities in China: Unlocking the Power of Cities for a Healthy China.' The Lancet 391:10135. https://doi.org/ 10.1016/So140-6736(18)30486-0.

Yue Zhang, M. 2016. 'Meso-Level Factors in Technological Transitions: The Development of TD-SCDMA in China.' Research Policy 45 (2): 546-59.

Zabaleta, I., C. Ferré-Pavia, A. Gutierrez, I. Fernandez, and N. Xamardo. 2014. 'Future Business Innovation in Minority Language Media.' Journalism Practise 8 (5): 508-18.

Zhang, J., and X.-J. Liang. 2012. 'Promoting Green IC T in China: A Framework Based on Innovation System Approaches.' Telecommunications Policy 36 (10-11): 997-1013.

Zhang, X., X. Ming, Z. Liu, Y. Qu, and D. Yin. 2019. 'A Framework and Implementation of Customer Platform-Connection Manufactory to Service (C P Ms) Model in Product Service System.' Journal of Cleaner Production 230:798-819.

Zoderer, B. M., E. Tasser, K.-H. Erb, P. S. Lupo Stanghellini, and U. Tappeiner. 2016. 'Identifying and Mapping the Tourists Perception of Cultural Ecosystem Services: A Case Study from an Alpine Region.' Land Use Policy 56:251-61. 
TABLE 1 Review of Scientific Publications Based on the Keywords 'Subscription Economy' AND 'Digital Media' And 'Theory of Decision' And 'Motivation Theory' (2004-2019)

\begin{tabular}{|c|c|}
\hline Authors (year) & Indicators/models/subjects \\
\hline $\begin{array}{l}\text { Bischof, Boettger and Rudolph } \\
(2 \mathrm{O} 2 \mathrm{O})\end{array}$ & $\begin{array}{l}\text { Subscriptions, curation, decision-making, risk, } \\
\text { interval }\end{array}$ \\
\hline $\begin{array}{l}\text { Netter, Pedersen and } \\
\text { Lüdeke-Freund (2019) }\end{array}$ & $\begin{array}{l}\text { Sharing economy, collaborative consumption, } \\
\text { conceptual boundaries business model }\end{array}$ \\
\hline Ritter and Schanz (2019) & $\begin{array}{l}\text { Business model, sharing economy, business model } \\
\text { innovation, value creation }\end{array}$ \\
\hline Martinez Dy (2019) & $\begin{array}{l}\text { Digital enterprise, entrepreneurship, } \\
\text { cyberfeminism, social embeddedness }\end{array}$ \\
\hline Rossi et al. (2019) & $\begin{array}{l}\text { Indicators, metrics, business model, sustainability, } \\
\text { circular economy }\end{array}$ \\
\hline Gielens and Steenkamp (2019) & Branding, digital intermediation \\
\hline Saavedra and González (2015) & $\begin{array}{l}\text { Willingness to pay (W TP), newspaper, subscription } \\
\text { plans, consumer decision-making }\end{array}$ \\
\hline Kumar, Lahir, and Dogan (2019) & $\begin{array}{l}\text { Sharing economy, customer development, } \\
\text { multigenerational marketing }\end{array}$ \\
\hline Perryer et al. (2016) & Pedagogy, motivation, game-based learning, gaming \\
\hline Ojala, Evers, and Rialp (2018) & $\begin{array}{l}\text { Digitalisation, digital platforms, } \\
\text { internationalisation, bottlenecks }\end{array}$ \\
\hline Lokuge et al. (2019) & $\begin{array}{l}\text { IT portfolio management, digital innovation, } \\
\text { readiness, case study, survey, CIO }\end{array}$ \\
\hline Phang et al. (2019) & $\begin{array}{l}\text { Consumer behaviour, China, data analytics, digital } \\
\text { economy, e-commerce, emerging markets, } \\
\text { empirical research, machine learning }\end{array}$ \\
\hline Phillips et al. (2019) & $\begin{array}{l}\text { Economic landscape, agricultural systems, digital } \\
\text { agriculture, interoperability, data }\end{array}$ \\
\hline Goldfarb and Tucker (2019) & $\begin{array}{l}\text { Internet marketing, digitalisation, digital economy, } \\
\text { online promotion, digital distribution }\end{array}$ \\
\hline Chipidza and Leidner (2019) & $\begin{array}{l}\text { IC T projects (information and communication } \\
\text { technology), literature, development, developing } \\
\text { countries }\end{array}$ \\
\hline Li et al. (2019) & $\begin{array}{l}\text { Virtual acculturation, social media, social contact, } \\
\text { social learning }\end{array}$ \\
\hline Park and Armstrong (2019) & Consumer motivations, online shopping \\
\hline Liu et al. (2019) & $\begin{array}{l}\text { Millennials, entrepreneur, international } \\
\text { entrepreneurship }\end{array}$ \\
\hline
\end{tabular}


TABLE 1 Continued from the previous page

\begin{tabular}{|c|c|}
\hline Authors (year) & Indicators/models/subjects \\
\hline Kannan and Hongshuang (2019) & $\begin{array}{l}\text { Digital marketing, internet/mobile (users), search } \\
\text { engine }\end{array}$ \\
\hline Galloway (2017) & $\begin{array}{l}\text { Attention, attention span, visual communication, } \\
\text { mobile PR }\end{array}$ \\
\hline $\begin{array}{l}\text { Brown, Woodhouse, and } \\
\text { Sioshansi (2019) }\end{array}$ & $\begin{array}{l}\text { Digitalisation, electricity, innovation, disruption, } \\
\text { new business strategies }\end{array}$ \\
\hline Nakano and Kondo (2018) & $\begin{array}{l}\text { Multichannel shopping behaviour, purchase stages, } \\
\text { behavioural data }\end{array}$ \\
\hline Shukla and Drennan (2018) & $\begin{array}{l}\text { Virtual consumption, multiplayer online } \\
\text { role-playing games, social network theory, online } \\
\text { communities }\end{array}$ \\
\hline $\begin{array}{l}\text { Spencer, Butalis, and Moital } \\
(2012)\end{array}$ & Technology adoption, decision-making, leadership \\
\hline Pick, Sarkar, and Johnson (2015) & $\begin{array}{l}\text { Technology utilisation, spatial, socio-economic } \\
\text { factors, policy }\end{array}$ \\
\hline Tan et al (2018) & $\begin{array}{l}\text { Mobile social media advertising, tourism products } \\
\text { and services, social media, mobile commerce }\end{array}$ \\
\hline $\begin{array}{l}\text { Holsapple, Hsiao, and Pakath } \\
(2018)\end{array}$ & Business social media analytics \\
\hline DeVoss and Porter (2006) & Ethics, Filesharing, Napster, Plagiarism \\
\hline $\begin{array}{l}\text { Browder, Aldrich, and Bradley } \\
(2019)\end{array}$ & $\begin{array}{l}\text { Innovation, learning, expertise, collaboration, 3D } \\
\text { printing, prototype, design }\end{array}$ \\
\hline Nishida, Pick, and Sarkar (2014) & $\begin{array}{l}\text { Japan, digital divide, ICT, IC T use factors, } \\
\text { regression }\end{array}$ \\
\hline $\begin{array}{l}\text { Calvo-Porral, Faí?a-Medín, and } \\
\text { Nieto-Mengotti (2017) }\end{array}$ & $\begin{array}{l}\text { Digital technologies, satisfaction, engagement, } \\
\text { interaction }\end{array}$ \\
\hline $\begin{array}{l}\text { Aleem, Faí?a-Medín, and } \\
\text { Nieto-Mengotti (2016) }\end{array}$ & $\begin{array}{l}\text { Software game, video game, online game, empirical } \\
\text { investigation }\end{array}$ \\
\hline Rhue and Sundararajan (2014) & Democracy, internet, social media, influence \\
\hline Laurent et al. (2015) & $\begin{array}{l}\text { Centralised model, identity and web } 2.0 \text {, } \\
\text { socio-technical processes, user-centric model }\end{array}$ \\
\hline Alderete (2019) & $\begin{array}{l}\text { Internet use, internet access, digital divide, ICT, } \\
\text { poor populations }\end{array}$ \\
\hline Howard et al. (2006) & Automotive e-hubs, barriers, interaction \\
\hline Bartikowski et al. (2018) & $\begin{array}{l}\text { Digital divide, majority and minority consumers, } \\
\text { mobile internet, wellbeing }\end{array}$ \\
\hline Aguiar and Martens (2016) & Digital music, copyright, downloading, streaming \\
\hline
\end{tabular}


TAB LE 1 Continued from the previous page

\begin{tabular}{|c|c|}
\hline Authors (year) & Indicators/models/subjects \\
\hline Beltagui, Kunz, and Gold (2019) & $\begin{array}{l}\text { Additive manufacturing, 3D printing, open source } \\
\text { innovation, social sustainability }\end{array}$ \\
\hline Salehan, Kim, and Lee (2018) & $\begin{array}{l}\text { ICT, national culture, globalisation, technology } \\
\text { adoption, technological innovation }\end{array}$ \\
\hline Das and Drine (2020) & $\begin{array}{l}\text { Catching-up, efficiency, stochastic frontier, human } \\
\text { capital }\end{array}$ \\
\hline Drachen et al. (2014) & $\begin{array}{l}\text { Game analytics, auction house, business } \\
\text { intelligence, game economy, player behaviour }\end{array}$ \\
\hline Scheaf et al. (2018) & Signals, media coverage, interaction \\
\hline $\begin{array}{l}\text { Bartolini, Santons, and Ulrich } \\
\text { (2018) }\end{array}$ & $\begin{array}{l}\text { Property, intellectual property, copyright, trade } \\
\text { secret, patents, dispute resolution, data protection }\end{array}$ \\
\hline Kabbiri et al. (2018) & $\begin{array}{l}\text { Extended technology adoption model, smart phone } \\
\text { use }\end{array}$ \\
\hline Hong et al. (2018) & $\begin{array}{l}\text { Value of online news contents, internet portal, } \\
\text { newspaper companies, revenue sharing }\end{array}$ \\
\hline Jansen (2020) & $\begin{array}{l}\text { Software ecosystem governance, focus area maturity } \\
\text { models }\end{array}$ \\
\hline Ding (2019) & $\begin{array}{l}\text { Appraisal theory, information system continuance } \\
\text { models, innovativeness }\end{array}$ \\
\hline Hutchins (2016) & $\begin{array}{l}\text { Mobile television, mobile media, copyright, football } \\
\text { leagues, Australia }\end{array}$ \\
\hline $\begin{array}{l}\text { Carbonell, Sánchez-Esguevillas, } \\
\text { and Carro (2015) }\end{array}$ & Emerging issues, weak signals \\
\hline Mäntymäki and Salo (2015) & $\begin{array}{l}\text { Virtual worlds, customer value, virtual purchasing, } \\
\text { virtual items }\end{array}$ \\
\hline $\begin{array}{l}\text { Marchand and Hennig-Thurau } \\
\text { (2013) }\end{array}$ & $\begin{array}{l}\text { Video games, entertainment industry, digital } \\
\text { distribution, social media }\end{array}$ \\
\hline MacKay et al. (2018) & $\begin{array}{l}\text { Fisheries management, non-compliance, } \\
\text { behavioural insights }\end{array}$ \\
\hline Alpar, Engler, and Schulz (2015) & Influence processes, reuse, social software \\
\hline Sim et al. (2014) & $\begin{array}{l}\text { Artificial neural networks, multilayer perception, } \\
\text { perceived credibility }\end{array}$ \\
\hline Ruotsalainen et al. (2017) & Renewable energy, social transformation \\
\hline Benlian and Hess (2011) & $\begin{array}{l}\text { Cloud computing, technology adoption, theory of } \\
\text { reasoned action }\end{array}$ \\
\hline Von Krogh and Spaeth (2007) & $\begin{array}{l}\text { Open source software, interdisciplinary research, } \\
\text { innovation }\end{array}$ \\
\hline
\end{tabular}


TAB BE 1 Continued from the previous page

\begin{tabular}{|c|c|}
\hline Authors (year) & Indicators/models/subjects \\
\hline Mabon (2020) & $\begin{array}{l}\text { Climate information services, Japan, risk } \\
\text { governance, social dimensions of climate change }\end{array}$ \\
\hline Ivaturi and Chua (2019) & Online communities, norms, beliefs \\
\hline Tyce (2020) & $\begin{array}{l}\text { Political settlement, innovation, mobile money, } \\
\text { Kenya }\end{array}$ \\
\hline Osman et al. (2019) & $\begin{array}{l}\text { Analytics, behavioural or, data envelopment } \\
\text { analysis }\end{array}$ \\
\hline Panda and Jain (2018) & $\begin{array}{l}\text { Personality theory, emotional ill-being, } \\
\text { personalities, physical ill-being, India }\end{array}$ \\
\hline Hinson (2010) & E-business, value chain, exports, internet, Ghana \\
\hline $\begin{array}{l}\text { Lyons, Hammond, and Mackay } \\
\text { (2019) }\end{array}$ & MaaS, user perspective, travel behaviour, integration \\
\hline Turner (2012) & Regulation, broadcasting, professional sport \\
\hline Peekhaus and Proferes (2016) & $\begin{array}{l}\text { Faculty experience, Library and Information } \\
\text { Studies, open access }\end{array}$ \\
\hline Hsiaofen Chen and Fu (2018) & $\begin{array}{l}\text { Hedonic value, mobile value, sociability value, } \\
\text { willingness-to-pay }\end{array}$ \\
\hline Mahmood and Sismeiro (2017) & News, social influence, latent space approach \\
\hline Bagwell (2007) & Survey, theory, empirical analysis \\
\hline $\begin{array}{l}\text { Konietzny, Caruana, and Cassar } \\
(2018)\end{array}$ & Online gambling, enjoyment \\
\hline Lee et al. (2019) & $\begin{array}{l}\text { Positive computing, mobile and wearable } \\
\text { technologies, IoT }\end{array}$ \\
\hline Schröder et al. (2019) & $\begin{array}{l}\text { Sustainable production, sustainable consumption, } \\
\text { emissions, research }\end{array}$ \\
\hline Funk (2017) & $\begin{array}{l}\text { Sport, consumer, design, user, experience, } \\
\text { technology }\end{array}$ \\
\hline Tomiyama et al. (2019) & Product development, design \\
\hline Li et al. (2016) & Cloud computing, cloud spot pricing \\
\hline Ferranti et al. (2019) & $\begin{array}{l}\text { European Union, Natura 2000, implementation } \\
\text { experience }\end{array}$ \\
\hline Zhang et al. (2019) & $\begin{array}{l}\text { Manufacturing system, mass customisation, } \\
\text { personalised customisation, model innovation }\end{array}$ \\
\hline Meade and Islam (2015) & Diffusion models, mobile telephony, internet \\
\hline Guo and Bouwman (2016) & $\begin{array}{l}\text { Mobile payment, merchants, adoption, analytical } \\
\text { framework }\end{array}$ \\
\hline
\end{tabular}


TABLE 1 Continued from the previous page

\begin{tabular}{|c|c|}
\hline Authors (year) & Indicators/models/subjects \\
\hline Mohr (2007) & Motion pictures, marketing, promotion \\
\hline Zhang and Liang (2012) & $\begin{array}{l}\text { Green ICT, innovation system, green innovation, } \\
\text { environmental sustainability }\end{array}$ \\
\hline $\begin{array}{l}\text { Wiener, Hoßbach, and Saunders } \\
\text { (2018) }\end{array}$ & $\begin{array}{l}\text { Dual business models, synergies and tensions, } \\
\text { business model integration }\end{array}$ \\
\hline Shin (2007) & $\begin{array}{l}\text { Information policy, telecommunication policy, } \\
\text { South Korea }\end{array}$ \\
\hline Shin and Jung (2012) & Socio-technical systems theory, South Korea \\
\hline Grajek and Kretschmer (2009) & $\begin{array}{l}\text { Usage intensity, consumer heterogeneity, } \\
\text { fixed-mobile substitution }\end{array}$ \\
\hline Mesak et al. (2011) & $\begin{array}{l}\text { Marketing, advertising, new subscriber services, } \\
\text { optimal control theory, service costs }\end{array}$ \\
\hline Al-Debei and Al-Lozi (2014) & Value dimensions, value-based approach, Jordan \\
\hline Abu Bakar and Bidin (2014) & Mobile advertising, marketing, movie advertising \\
\hline Shin and Kweon (2011) & $\begin{array}{l}\text { Broadband ecology, South Korea, socio-technical } \\
\text { perspective, structural equation model }\end{array}$ \\
\hline Boissy et al. (2012) & Publishing, business, interviews \\
\hline Binder (2016) & $\begin{array}{l}\text { Fisher effect, gold standard, hyperinflation, great } \\
\text { depression, debt deflation }\end{array}$ \\
\hline Fedorowicz et al. (2014) & Digital government, public safety networks \\
\hline $\begin{array}{l}\text { Suddaby, Viale, and Gendron } \\
(2016)\end{array}$ & $\begin{array}{l}\text { Institutions, organisational fields, social position, } \\
\text { social skill }\end{array}$ \\
\hline $\begin{array}{l}\text { Arena, Azzone, and Mapelli } \\
(2018)\end{array}$ & $\begin{array}{l}\text { Drivers for evolution, energy sector, institutional } \\
\text { logics }\end{array}$ \\
\hline $\begin{array}{l}\text { Belleflamme, Omrani, and Peitz } \\
\text { (2015) }\end{array}$ & $\begin{array}{l}\text { Platform markets, network effects, asymmetric } \\
\text { information, P2 P lending }\end{array}$ \\
\hline Wohlmann (2012) & $\begin{array}{l}\text { Blogs, entrepreneur of the self, life writing, age } \\
\text { awareness }\end{array}$ \\
\hline Aczel, Peake, and Hardy (2008) & $\begin{array}{l}\text { ICT for development, learning communities, } \\
\text { pedagogical issues }\end{array}$ \\
\hline Yue Zhang (2016) & $\begin{array}{l}\text { Technological transition, } 3 \mathrm{G} \text { mobile networks, } \\
\text { China }\end{array}$ \\
\hline $\begin{array}{l}\text { Rymaszewska, Helo, and } \\
\text { Gunasekaran (2017) }\end{array}$ & IoT, servitization, manufacturing, creation \\
\hline Currie (2012) & TEMPEST, technology, stakeholders \\
\hline Keller, Lyoyd, and Bell (2015) & $\begin{array}{l}\text { Gender, culture, feminism, productivism, symbolic } \\
\text { boundaries }\end{array}$ \\
\hline
\end{tabular}


TABLE 1 Continued from the previous page

\begin{tabular}{|c|c|}
\hline Authors (year) & Indicators/models/subjects \\
\hline $\begin{array}{l}\text { Ojo, Janowski, and Awotwi } \\
\text { (2013) }\end{array}$ & $\begin{array}{l}\text { Mobile services, development, structuration theory, } \\
\text { vulnerable groups }\end{array}$ \\
\hline $\begin{array}{l}\text { Rangaswamy, Giles, and Seres } \\
(2009)\end{array}$ & Search engines, business impact \\
\hline Stocker and Whalley (2018) & $\begin{array}{l}\text { Internet access, broadband, consumer experience, } \\
\text { Ofcom }\end{array}$ \\
\hline $\begin{array}{l}\text { Gupta, Seetharaman, and Raj } \\
\text { (2013) }\end{array}$ & $\begin{array}{l}\text { Cloud computing, Software-as-a-Service, } \\
\text { Platform-as-a-Service, smEs }\end{array}$ \\
\hline Harris, Wang, and Wang (2015) & $\begin{array}{l}\text { Multimodal transport, ІС } \text {, technological trends, } \\
\text { cloud computing, Internet of Things }\end{array}$ \\
\hline Borés, Saurina, and Torres (2003) & Technological uncertainty, strategy, IC T \\
\hline Majumdar (2008) & $\begin{array}{l}\text { IC T, public policy, Us telecommunications } \\
\text { industry, wage structure }\end{array}$ \\
\hline Liburd (2012) & Tourism research, epistemology, web 2.o, paradigm \\
\hline Spiekermann and Novotny (2015) & $\begin{array}{l}\text { Personal data market, economics of personal } \\
\text { information, privacy regulation }\end{array}$ \\
\hline Messinger et al. (2009) & Virtual worlds, gaming, avatars \\
\hline Jang et al. (2015) & $\begin{array}{l}\text { Demand response, critical peak pricing, response } \\
\text { index, heterogeneity }\end{array}$ \\
\hline Tallberg et al. (2007) & Service adoption, regulation, competition \\
\hline Chik (2011) & $\begin{array}{l}\text { Google video search engine, internet intermediaries } \\
\text { regulation, safe harbour, fair use }\end{array}$ \\
\hline Ooi et al. (2011) & $\begin{array}{l}\text { Broadband, Malaysia, adoption, consumer } \\
\text { behaviour, structural equation modeling, } \\
\text { developing countries }\end{array}$ \\
\hline Sandvig (2004) & Innovation, popularisation, internet infrastructure \\
\hline Otto et al. (2013) & $\begin{array}{l}\text { Interoperability service utilities, business model, } \\
\text { reference model }\end{array}$ \\
\hline Godoe and Hansen (2009) & $\begin{array}{l}\text { Innovation regimes, technological regimes, } \\
\text { entrepreneurship, communications }\end{array}$ \\
\hline $\begin{array}{l}\text { Van Gorp, Maitland, and } \\
\text { Hanekop (2006) }\end{array}$ & Internet, technology, firm, market, competition \\
\hline Aapaoja et al. (2017) & $\begin{array}{l}\text { IT platform, business models, service concepts, } \\
\text { e-marketplace }\end{array}$ \\
\hline Palvia, Baqir, and Nemati (2018) & Socio-economic development, impacts \\
\hline Clemons (2009) & $\begin{array}{l}\text { Advertising, monetising the internet, online } \\
\text { revenue without advertising, social networks }\end{array}$ \\
\hline
\end{tabular}


TABLE 1 Continued from the previous page

\begin{tabular}{|c|c|}
\hline Authors (year) & Indicators/models/subjects \\
\hline Baron (2004) & $\begin{array}{l}\text { Computers, culture, email address, integrational } \\
\text { linguistics technology, writing }\end{array}$ \\
\hline Shaffer and Arkes (2009) & Preference reversals, incentives \\
\hline Kirs and Bagchi (2012) & Trust, IC T related phenomenon \\
\hline Turner and Shilbury (2005) & Sports, broadcasting, Australia \\
\hline Wang (2015) & $\begin{array}{l}\text { Technology excellence, Service experience, mobile } \\
\text { services }\end{array}$ \\
\hline Kang and Downing (2015) & $\begin{array}{l}\text { wimax, } 3 \mathrm{G} \text {, two-sided markets, market entry, } \\
\text { indirect network effect }\end{array}$ \\
\hline Singh, Payal, and Bharti (2019) & $\begin{array}{l}\text { Cyber physical system, cloud computing, Internet of } \\
\text { Things (IoT) }\end{array}$ \\
\hline Green and Peloza (2015) & $\begin{array}{l}\text { Social responsibility, corporations, recession, } \\
\text { advertising }\end{array}$ \\
\hline Reed et al. (2012) & Identity, consumer behaviour \\
\hline Servia-Rodríguez et al. (2014) & Social Web, data mining, tie strength, social spheres \\
\hline Venkatesh and Chatterjee (2006) & Online content, print, offer \\
\hline Sorescu et al. (2011) & Retailing, innovations, value creation \\
\hline Acheson and Maule (2006) & International trade, cultural goods \\
\hline Yang et al. (2018) & China, health, cities \\
\hline Zoderer et al. (2016) & $\begin{array}{l}\text { Ecosystem service mapping, Ecosystem service } \\
\text { potential }\end{array}$ \\
\hline Johnson (2005) & Libraries, Iraq, war \\
\hline Purtova (2009) & Data protection, property in personal data \\
\hline Brydon and Vining (2006) & Knowledge management, public good \\
\hline Menell and Scotchmer (2007) & Innovation, patent, copyright, trade secret \\
\hline Saha (2005) & Pervasive computing \\
\hline McClellan, Low, and Tan (2004) & ICT, technological issues \\
\hline Boccaletti et al. (2014) & Networks, processes, dynamics \\
\hline
\end{tabular}




\section{Abstracts in Slovene}

\section{Začetno financiranje hrvaških MSP-jev: dokazi iz finančnih poročil Roberta Kontošić Pamić in Adriana Galant}

Ena izmed glavnih odločitev, ki jo je treba sprejeti ob začetku poslovanja, je način financiranja dotičnega posla. Podjetnik lahko izbira med različnimi možnostmi, najpogosteje uporabljeni viri financiranja pa vključujejo lastna sredstva podjetnika (-ov) ali kombinacijo lastnih in izposojenih finančnih sredstev. Zaradi zakonskih zahtev je na $\mathrm{Hr}-$ vaškem teoretično nemogoče ustanoviti podjetje brez lastnih sredstev, vendar pa je podjetje možno ustanoviti samo za simbolično količino vloženih lastnih finančnih sredstev. Zaradi pomanjkanja poslovnih izkušenj in premoženja, ki bi lahko služilo kot neko jamstvo za novo podjetje, bi le-to težko dobilo posojilo pri finančnih institucijah. Cilj pričujočega članka je analizirati, ob upoštevanju različnih razpoložljivih načinov financiranja novih poslov, kako se financirajo novouveljavljeni hrvaški MSP-ji. Izvedena raziskava je pokazala, da novi podjetniki za financiranje svojega posla uporabijo več izposojenih kot lastnih finančnih sredstev.

Ključne besede: podjetništvo, financiranje, poročila, MsP-ji, Hrvaška Klasifikacija JEL: L26, M41

Managing Global Transitions 18 (4): 265-283

\section{Razmerje med občinskim upravljanjem in kakovostjo zagotavljanja} na občinski ravni

Kgobalale N. Motubatse in Collins C. Ngwakwe

Ta članek preučuje razmerje med kakovostjo upravljanja občin in kakovostjo zagotovil. Ustreznost Članek je relevanten zaradi poslabšanja stanja izvajanja občinskih storitev in ponavljajočih se poročilih generalnega revizorja Južne Afrike (2016) o slabem finančnem poslovodenju v veliki večini južnoafriških občin. Cilj prispevka je torej analizirati razmerje med kakovostjo upravljanja občin (s pomočjo poročil o uspešnosti izvajanja) in kakovostjo občinskih zagotovil (s pomočjo kakovosti računovodskih izkazov). Podatki so bili zbrani iz arhivov konsolidiranih revizijskih poročil generalnega revizorja za proračunski leti 2016/2017 in 2017/2018. Ti so bili podvrženi kvantitativni analizi z uporabo regresijskih metod pregleda fiksnih in naključnih učinkov na podatke. Ugotovitve statistične analize v obeh modelih kažejo, da je ka- 
kovost poročil o uspešnosti bistveno povezana s kakovostjo zagotavljanja, z vrednostjo p manj kot o,05. Ugotovitve kažejo, da je resnično izboljšanje izvajanja javnih služb in finančnega upravljanja v občinah odvisno od stopnje izboljšanja kakovosti upravljanja, slednje pa zahteva, da se birokrati posvetijo zdaj že večletnemu vprašanju slabe kakovosti upravljanja. Pričujoči članek ponuja praktična in na raziskavah temelječa priporočila, med katerimi je najpomembnejša potreba po izvajanju četrtletnih pregledov kakovosti upravljanja in zagotovil v občinah, s čimer se izognemo podaljšanim zamudam, povezanim $\mathrm{z}$ letnim revizijskim ciklom. Drugo priporočilo je namenjeno nadaljnjim raziskavam, ki naj preučijo razmerje med kakovostjo upravljanja in kakovostjo zagotavljanja na področju državne uprave, s čimer bi se ugotovilo, v kolikšni meri so izzivi podobni tistim na občinski ravni.

Ključne besede: računovodski izkaz, finančno poslovodenje, upravljanje občin, poročilo o zanesljivosti, poročilo o uspešnosti, izvajanje storitev Klasifikacija JEL: $\mathrm{H} 79, \mathrm{H} 83$

Managing Global Transitions 18 (4): 285-300

\section{Vseprisotni socialni mediji: si lahko zamislimo potovanje brez pametnih naprav? \\ Zsuzsanna Marton in Ildikó Ernszt}

Če so se včasih ljudje odpravili na počitnice zaradi sprostitve in občutka pobega od običajnega delavnika, si danes večina ljudi ne predstavlja, da bi med potovanji preživeli nekaj dni brez internetne povezave ali pametnih telefonov. $\mathrm{V}$ prednosti uporabe pametnih telefonov in družabnih medijev ni mogoče podvomiti, vendar pa je treba upoštevati tudi slabosti le-te. Da bi razkrili slabosti in prednosti pojava, je najprej predstavljen kratek teoretični pregled teme, nato pa je v ospredje pričujočega članka postavljena analiza rezultatov empirične raziskave, v kateri je sodelovalo 386 ljudi na Madžarskem. Spletna raziskava, izvedena jeseni 2019, je omogočila preučevanje navad Madžarov pri uporabi mobilnih telefonov in družabnih omrežij med počitnicami. Za ponazoritev dojemanja in odnosa anketirancev ter za razlago skritih razmerij med spremenljivkami smo uporabili preprosto opisno statistiko in metodo večdimenzionalnega skaliranja (MDS) s postopkom ALSCAL. Rezultati kažejo, da so pametna orodja in socialni mediji naravni del počitnic: $90 \%$ anketirancev dnevno uporablja platformo socialnih medijev, kot je recimo Facebook, $48 \%$ pa jih je dejalo, da med počitnicami manj uporabljajo mobilne telefone kot drugače. Vendar bi jih bilo le 13,5\% pripravljenih v celoti omiliti uporabo pametnih naprav, medtem ko je v primeru uporabe družbenih omrežij ta delež večji, 37,9 \%. 
Ključne besede: turizem, pametna orodja, socialni mediji, vedenje potrošnikov, digitalno razstrupljanje

Klasifikacija JEL: Z33

Managing Global Transitions 18 (4): 301-321

\section{Globalni prehod na naročniško gospodarstvo: pregled literature o spremembah poslovnega modela v medijskem prostoru Alenka Lena Klopčič, Jana Hojnik, Štefan Bojnec in Drago Papler}

Poslovni modeli medijskih korporacij in organizacij so doživeli izrazit prehod, ki je $\mathrm{v}$ zadnjem desetletju povzročil pomembne spremembe, saj so se $\mathrm{z}$ modela, ki temelji na prihodkih od oglaševanja in naklad tiskanih kopij, preusmerile v model, ki temelji na naročnini. Kot je prikazano $\mathrm{v}$ tem članku, tradicionalni mediji trenutno eksperimentirajo $\mathrm{z}$ »različnimi mešanicami plačilnih zidov«. Med modeli, na katere prehajajo medijska podjetja, je tudi model naročniškega gospodarstva, torej praksa zaračunavanja občinstvu za dostop do spletnih vsebin, ki so bile do nedavnega odklenjene in/ali prosto dostopne. Mimogrede, propad »oglaševalskega modela", skupaj s posledicami svetovne recesije, je za tradicionalne medije povzročil znatno gospodarsko negotovost in jih spodbudil $k$ iskanju novih poslovnih strategij za trajnostno novinarstvo, hkrati pa sprožil razmislek o celotni prihodnosti medijev. Na podlagi pregleda literature je cilj pričujočega članka opisati in predstaviti dejanske spremembe $\mathrm{v}$ medijskem prostoru $\mathrm{v}$ povezavi $\mathrm{z}$ naročninskim gospodarstvom. Tako smo izvedli sistematičen pregled literature, ki je vseboval naslednje izraze: »naročniško gospodarstvo«, »digitalni mediji «, »teorija odločanja « in »teorija motivacije«. Dobili smo 145 rezultatov ustreznih znanstvenih in raziskovalnih člankov, ki so bili objavljeni v zadnjih 15 letih. Glavne ugotovitve so pokazale, da se medijski prostor spreminja hitro, še zlasti glede na razvoj in implementacijo novih digitalnih orodij. V skladu s tem pa hitro naraščajo "nekonvencionalna" konkurenca konvencionalnim medijem, potrebe novih generacij in njihovo tozadevno vedenje ter nujna potreba po različnih novih poslovnih modelih.

Ključne besede: naročniško gospodarstvo, digitalni mediji, teorija odločanja, motivacijska teorija

Klasifikacija JEL: L 82, L 86

Managing Global Transitions 18 (4): 323-348 